\title{
Bibliography of the
}

Geology of the

Western Phosphate

Field

GEOLOGICA L S URVEY B ULLETIN 1018

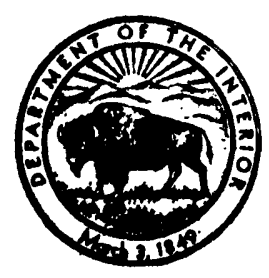





\section{CONTENTS}

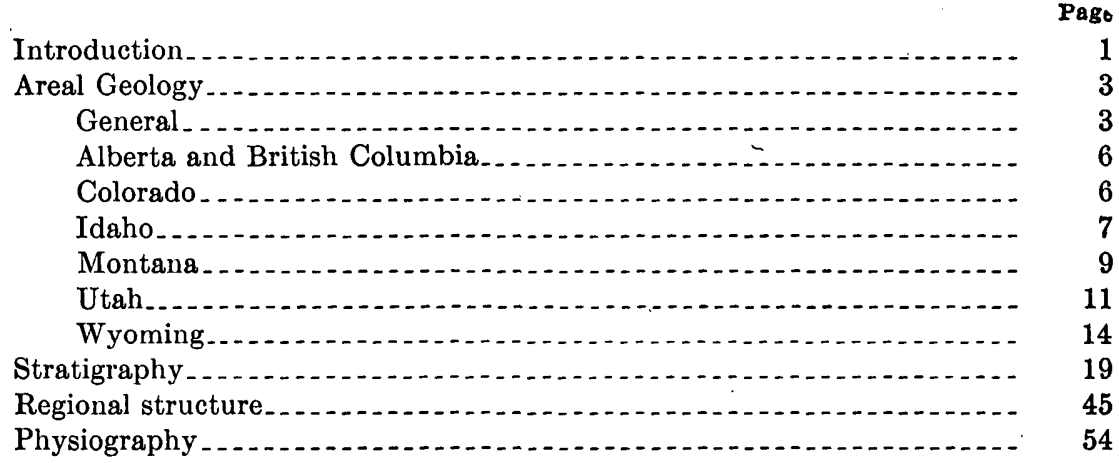

Fauna and flora of the Phosphoria formation and its partial stratigraphic equivalents in the western field.......................................

Mineralogy and chemical composition of the Phosphoria and Park City formations. . . . . . . .

Mineralogy and chemical composition of phosphorites...................

Origin of the Phosphoria formation and its mineral deposits........... Reserves, mining, production, and utilization of western phosphate rock.Oil bituminous material, vanadium, and minor elements in the Phosphoria formation and its partial stratigraphic equivalents in the western field.Other mineral deposits and fuels in the western phosphate field........... 



\title{
BIBLIOGRAPHY OF THE GEOLOGY OF THE WESTERN PHOSPHATE FIELD
}

\author{
By Robert A. Harris, David F. Davidson, and Bertha P. Arnold
}

\section{INTRODUCTION}

The bibliography of the geology of the western phosphate field was compiled for the use of geologists of the Geological Survey engaged in extensive and diverse geological studies in many parts of the region. It is now published as an aid to others who are interested in the phosphate deposits or in other aspects of the geology of the region.

The entries are classified and liberally cross-indexed under the headings listed in the table of contents. The section on areal geology includes only the publications that describe the geology of the area containing the Phosphoria formation of Permian age or its partial stratigraphic equivalents, the Park City and Embar formations. The sections on stratigraphy, on regional structure, and on other mineral deposits and fuels contain references to publications describing those aspects of areas within the western phosphate field as a whole-publications that will be of interest, for example, to one mapping the geology of a region in which he has had little previous experience, or attempting to work out its stratigraphy, structure, or physiography. A section on mineralogy and chemical composition of phosphorites in other regions has been included.

Entries in which the Phosphoria, Park City, or Embar formations are mentioned by name are marked by an asterisk. The date shown at the beginning of an entry is that of the first published use of the title, whether used for an abstract or the complete paper.

An attempt has been made to include all papers published prior to September 1952 dealing specifically with the western phosphate deposits and the Phosphoria formation with its immediate stratigraphic equivalents. Coverage of the general geology of the field is incomplete, although it is believed that most published papers are listed. Encyclopedias and text books with only casual mention of the phosphate deposits have not been listed.

Special thanks are due the libraries of the University of California at Berkeley, the University of Idaho at Moscow, the University of Washington at Seattle, Washington State College at Pullman, and the Spokane Public Library for use of their facilities and their help. Many other libraries throughout the country have lent material. 



\section{AREAL GEOLOGY}

\section{GENERAL}

Alden, W: C., 1924, Physiographic development of the northern Great Plains: Geol. Soc. America Bull., v. 35, no. 3,.p. 385-423.

1925, Pre-Wisconsin glaciation of northern Rocky Mountains [abs.] : Pan-Am. Geologist, v. 43, no. 5, p. 371-372.

Anderson, A. L., 1952, Multiple emplacement of the Idaho batholith: Jour. Geology, v. 60, no. 3, p. 255-265.

Atwood, W. W., and Atwood, W: W., Jr., 1938, Working hypothesis : for the physiographic history of the Rocky Mountain region: Geol. Soc. America Bull., v. 49, no. 6, p. 957-980.

*Baker, A. A., and Williams, J. Steele,. 1939, Permian in parts of Rocky Mountain and Colorado Plateau regions: Am. Assoc. Petroleum Geologists Bull., v. 24, no. 4, p. 617-635, 1940; abs., Oil Weekly, v. 93, no. 3, p. 70.

Blackwelder, Eliot, 1915, Origin and development of the Rocky Mountains in the United States [abs.] : Assoc. Am. Geographers Annals, v. 5, p. 137.

Boardman, Leona, 1949, Geologic mapping in the United States: Geol. Soc. America Bull., v. 60, no. 7, p. 1125-1131.

1947-1952, Index to geologic mapping in the United States: U. S. Geol. Survey. By States, at various scales.

Branson, E. B., 1926, Correlation of Mississippian section of Rocky Mountain States and Mississippi Valley States [abs.] : Pan-Am. Geologist, $\nabla_{i}$ 45, no. 3, p. 248.

Butler, B. S., 1933, Summary, Pt. 1 of Ore deposits related to stratigraphic struc: tural, and igneous geology in the western United States, in Ore deposits of the Western States (Lindgren Volume), p. 198-240: New York, Am. Inst. Min. Metall. Eng.

*Campbell, M. R., and others, 1915, Guidebook of the western United States Part A, The Northern Pacific route with a side trip to Yellowstone Park: U. S. Geol. Survey, Bull. 611, 212 p.

*Clabaugh, P. S., 1946, Permian phosphate deposits of Montana, Idaho, Wyoming, and Utah: U. S. Geol. Survey Strategic Minerals Inv. Prelim. Map 3-198. Scale $1: 1,000,000$.

Crickmay, C. H., 1931, Jurassic History of North America-Its bearing on the development of continental structures: Am. Philos. Soc. Proc., v. 70, no. 1, p. 15-102.

Daly, R. A., 1912, Geology of the North American Cordillera at the forty-ninth parallel : Canada Geol. Survey Mem. 38. Map, scale 1: 62,500.

Eardley, A. J., 1946, Paleozoic Cordilleran geosyncline and related orogeny : Jour. Geology, v. 55, no..4, p. 309-342, 1947; abs., Geol. Soc. America Bull. v. 57, no. 12 , pt. 2, p. 1189.

1947, Late Cenozoic trenches of the Rocky Mountains [United States and Canada; abs.] : Geol. Soc. America Bull., v. 58, no. 12, pt: 2, p. 1176.

- 1951, Structural geology of North America: 624 p., New York, Harper \& Brothers. Maps, various scales.

Fenneman, N. M., 1931, Physiography of western United States: 534 p., New York, McGraw-Hill Book Co., Inc. 
Flint, R. T., 1924, A brief review of Rocky Mountain structure : Jour. Geology, v. 32, no. 5, p. 420-425.

Frémont, Capt. J. C., 1844, Map of an exploring expedition to the Rocky Mountains in 1842 and to Oregon and North California in the years 1843-1844.

Gilbert, G. K., 1928, Studies of Basin Range structure: U. S. Geol. Survey Prof. Paper 153, $92 \mathrm{p}$.

Hall, James, 1852, Geology and paleontology, in Stansbury, Howard, Exploration and survey of the valley of the Great Salt Lake of Utah, including a reconnaissance of a new route through the Rocky Mountains: Cong. Doc., 32d. Cong., Special sess., S. Exec. Doc. 3, p. 399-414, Philadelphia.

Hayden, F. V., 1872, [Geologic map of] Montana and Wyoming Territories, embracing most of the country drained by the Madison, Gallatin, and upper Yellowstone Rivers: U. S. Geol. Survey Terr. Scale 1 in. to $4 \mathrm{mi}$.

1877, Geological and geographical atlas of Colorado and portions of adjacent territory : New York, U. S. Geol. Geog. Survey Terr.

- 1878, Preliminary report of the field work of the U. S. Geological and Geographical Survey of the Territories for the season of 1878: 29 p., Washington, U. S. Geol. Geog. Survey Terr.

- 1883?, General geologic map of the area explored and mapped by Dr. F. V. Hayden and the surveys under his charge, 1869-1880. Scale 1: $2,600,000$

- 1883?, Twelfth annual report of the U. S. Geological and Geographical Survey of the Territories, for the year 1878, in two parts. [1883] : 809, $503 \mathrm{p}$. Map, scale $1: 2,600,000$.

*Heaton, R. L., 1933, Ancestral Rockies and Mesozoic and late Paleozoic stratigraphy of Rocky Mountain region: Am. Assoc. Petroleum Geologists Bull., v. 17, no. 2, p. 109-124.

*__ 1937, Stratigraphy versus structure in the Rocky Mountain region : Am. Assoc. Petroleum Geologists Bull., v. 21, no. 10, p. 1241-1267.

Howell, B. F., and others, 1944, Correlation of the Cambrian formations of North America: Geol. Soc. America Bull., v. 55, no. 8, p. 993-1003.

Irwin, J. S., 1926, Faulting in the Rocky Mountain region: Am. Assoc. Petroleum Geologists Bull., v. 10, no. 2, p. 105-129.

Jones, W. A., 1872, Report *** of a survey and exploration in the Uinta Mountains, Utah: U. S. [War Dept.] Chief of Engineers Ann. Rept., 1872: Cong. Doc., 42d Cong., 3d sess., H. Exec. Doc. 1, pt. 2, v. 2, p. 1108-1118.

Keith, Arthur, 1928, Structural symmetry in North America: Geol. Soc. America Bull., v. 39, no. 1, p. 321-385.

King, Glarence, 1873-1878, Annual reports upon the geological exploration of the fortieth parallel from the Sierra Nevada to the eastern slope of the Rocky Mountains: Washington, Govt. Printing Office.

King, P. B., 1932, An outline of the structural geology of the United States: Internat. Geol. Cong, 16th sess., United States, 1933, Guidebook 28.

Knight, S. H., 1942, The physical evolution of the Rocky Mountains [abs.] : Tulsa Geol. Soc. Digest, v. 10, 1941-42, p 36.

Lake, C. L., 1920, Episodes in Rocky Mountain orogeny : Am. Jour. Sci., 5th sel., v. 1, no. 13, p. 245-254, 1.921 ; abs., science, new ser., v. 51, p. 520-521.

* Lee, W. T., and others, 1915, Guidebook of the western United States-Part B, The overland route, with a side trip to Xellowstone Park: U. S. Geol. Survey Bull. 612, 244 p.

Longwell, C. R., 1944, Tectonic map of the United States: Am. Assoc. Petroleum Geologists Bull., v. 28, no. 12, p. 1767-1774. Map. scale 1: 2,500,000. 
- Mansfield, G. R., 1931, Some problems of the Rocky Mountain phosphate field: Econ. Geology, v. 26, no. 4, p. 353-374.

* _ 1933, The western phosphate field, in Ore deposits of the Western States (Lindgren Volume), p. 491-496: New York, Am. Inst. Min. Metall. Eng.

Moore, R. C., and others, 1944, Correlation of Pennsylvania formations of North America : Geol. Soc. America Bull., v. 55, no. 6, p. 657-706.

Nolan, T. B., 1943, The Basin and Range province in Utah, Nevada, and California: U. S. Geol. Survey Prof. Paper 197-D, p. 141-196.

Powell, J. W., 1877, Report on the geographical and geological survey of the Rocky Mountain region : $19 \mathrm{p}$., map, Washington.

1878 , Report on the lands of the arid region of the United States, with a more detailed account of the lands of Utah: Cong. Doc., 45th Cong. $2 \mathrm{~d}$ sess., H. Exec. Doc. 73, 195 p., maps ; 2 d ed., 1879.

Pruess, Charles, 1850, Topographical maps of the road from Missouri to Oregon [region traversed by Frémont], in 7 sections: Cong. Doc., 30th Cong., 2d sess., H. Doc. 145, v. 2.

Ransome, F. L., 1915, The Tertiary orogeny of the North American Cordillera and its problems, in Problems of American geology, p. 287-386: New Haven, Yale University. Maps, various scales.

Reeside, J. B., 1944, Maps showing thickness and general character of the Cretaceous interior of the United States: U. S. Geol. Survey Oil and Gas Inv. Prelim. Map 10. Scale 1 in. to $220 \mathrm{mi}$.

Resser, C. E., 1929, Cambrian geology of the Rocky Mountains : Smithsonian Inst. Explor. and Field Work, 1928, p. 21-26.

-1930, Further studies of Cambrian geology in the Rocky Mountains: Smithsonian Inst. Explor. and Field work, 1929, p. 23-30.

Schuchert, Charles, 1923, Sites and nature of the North American geosynclines: Geol. Soc. America Bull., v. 34, no. 2, p. 151-229.

* 1933, Correlation of more important marine Permian sequences: Geol. Soc. America Bull., v. 46, no. 1, p. 1-46, 1935 ; abs., Pan-Am. Geologist, v. 60, no. 3, p. 240, 1933; Internat. Geol. Cong., 16th, United States, 1933, Rept., จ. 1, p. 701, 1936.

Smith, J. P., 1901, The borderline between Paleozoic and Mesozoic in Western America : Jour. Geology, v. 9, p. 512-521.

-1904, The comparative stratigraphy of the marine Triassic of Western America : Calif. Acad. Sci. Proc., 3d ser., v. 1, p. 323-430.

Stille, Hans W., 1940, Einführing in den Bau Amerikas : 717 p., Berlin, Gebrueder Borntraeger.

Stose, G. W., and Ljungstedt, O. A., 1932, Geologic map of the United States: Washington, U. S. Geol. Survey. Scale $1: 2,500,000$.

Swartz, C. K., and others, 1942, Correlation of the Silurian formations of North America : Geol. Soc. America Bull., v. 53, no. 4, p. 533-538.

* Uren, L. C., 1938, Economics and geology of the Rocky Mountain area: World Petroleum, v. 9, no. 8, p. 34-49; no. 9 , p. 50-64; no. 10, p. 46-62.

Ver Wiebe, W. A., 1930, Ancestral Rocky Mountains: Am. Assoc. Petroleum Geologists Bull., v. 14, no. 6, p. 765-788.

* White, C. David, 1924, Permian of western America from the paleobotanical standpoint: Pan-Pacific Sci. Cong., Australia, 1923, Proc., v. 2, p. 1050-1077.

* Williams, J. Steele, 1936, Stratigraphic sections and faunules of some western Carboniferous formations at, or near, the type localities [abs.]: Geol. Soc. America Proc., 1935, p. 118-119.

1947, Mississippian-Pennsylvanian boundary problems in the Rocky Mountain region: Jour. Geology, v. 36, p. 327-351, 1948; abs., Geol. Soc. America Bull., v. 58, p. 1280. 
* Willis, Bailey, 1912, Index to the stratigraphy of North America: U. S. Geol. Survey Prof. Paper 71, p. 485-486, 494-495.

\section{ALBERTA AND BRITISH COLUMBIA}

* Adams, F. D. and Dick, W. J., 1915, Discovery of phosphate of lime in the Rocky Mountains : 36 p., Canada Comm. Conservation.

* Crockford, M. B. B., and Warren, P. S., 1935, The Cache Creek series of British Columbia: Royal Soc. Canada Trans., 3rd ser., v. 29, sec. 4, p. 160.

* De Schmid, H. S., 1916, Investigation of a reported discovery of phosphate in Alberta: Canada Mines Br. Bull. 12, 38 p.

* 1917, A reconnaissance for phosphate in the Rocky Mountains; and for graphite near Cranbrook, B. C.: Canada Mines Br. Summary Rept., 1916, p. 22-35.

Mathews, W. H., 1952, Mount Garibaldi, a supraglacial Pleistocene volcano in Southwestern British Columbia: Am. Jour. Sci., v. 250, no. 2, p. 81-103.

Spence, H. S., 1920, Phosphate in Canada, p. 104-105: Canada Mines Br. Rept. 396.

* Telfer, L., 1933, Phosphate in the Canadian Rockies : Canadian Inst. Mining and Metallurgy Trans., v. 36, p. 566-605.

Warren, P. S., 1927, Banff area, Alberta: Canada Geol. Survey Mem. 153, 94 p.

\section{COLORADO}

Barb, C. F., 1944, Hydrocarbons of the Uinta Basin of Utah and ColoradoReview of geology and field work; with a section by Ball, J. D., Survey of bitumen analyses and extraction methods: Colo. School Mines Quart., v. 39, no. 1, 115 p.

Bass, N. W., 1946, Subsurface mines of the Rangely anticline, Rio Blanco County, Colo.: U. S. Geol. Survey Oil and Gas Inv. Prelim. Map 67. Scale 1 in. to about $1 / 2 \mathrm{mi}$.

- Bench, B. M., 1945, The Rangely oil and gas field and Uinta Basin: Mines Mag., v. 35, no. 10, p. 516-524, 532, 594, 596.

Boardman, Leona, and Brown, Annabel, 1948, Geologic map index of Colorado: U. S. Geol. Survey. Scale 1:750,000.

Burbank, W. S., and others, 1935, Geologic map of Colorado: U. S. Geol. Survey, in cooperation with Colo. Geol. Survey and Colo. Metal Mining Fund. Scale $1: 500,000$.

Duncan, D. C., and Belser, Carl, 1950, Geology and oil-shale resources of the eastern part of the Piceance Creek basin, Rio Blanco and Garfield Counties, Colo.: U. S. Geol. Survey Oil and Gas Inv. Map OM 119. Scale 1 in. to $8,000 \mathrm{ft}$.

Gale, H. S., 1908, Geology of the Rangely oil district, Rio Blanco County, Colo., with a section on the water supply: U. S. Geol. Survey Bull. 350, 61 p.

George, R. D., 1927, Geology and natural resources of Colorado : Boulder, Colo., Colo. Univ. Press p. 51.

- Hancock, E. T., 1925, Geology and coal resources of the Axial and Monument Butte quadrangles, Moffat County, Colo.: U. S. Geol. Survey Bull. 757, p. 8-10. Map, scale $1: 62,500$.

Hayden, F. V., 1877, Geological and geographical atlas of Colorado and portions of adjacent territory : New York, U. S. Geol. Geog. Surv. Terr.

* Pickering, W. Y., and Dorn, C. L., 1948, Rangley oil field, Rio Blanco County, Colo.; in Structure of typical American oil fields, v. 3, p. 132-152: Tulsa, Okla., Am. Assoc. Petroleum Geologists.

Roy, C. J., and Hussey, K. M., 1952, Mass wasting on Table Mountain, Fremont County, Colo. ; Am. Jour. Sci., v. 250, no. 1, p. 35-45. 
* Sears, J. D., 1925, Geology and oil prospects of parts of Moffat County, Colo., and southern Sweetwater County, Wyo.: U. S. Geol. Survey Bull. 751, p. 283-284, 314-318. Map, scale $1: 125,000$.

* Thomas, C. R., and others, 1944, Structure contour map of the exposed rocks of the Rangely anticline, Rio Blanco and Moffat Counties, Colo.: U. S. Geol. Survey Oil and Gas Inv. Prelim. Map 7: Scale 1 in. to $1 / 2 \mathrm{mi}$.

- 1945, Structure contour maps of the Rangely anticline, Rio Blanco and Moffat Counties, Colo.: U. S. Geol. Survey Oil and Gas Inv. Prelim. Map 41. Scale 1 in. to $1 / 2 \mathrm{mi}$.

United States Geological and Geographical Survey of the Territories, 1878, Atlas. Maps, geological and geographical, at various scales.

* Unterman, G. E., and Unterman, B. R., 1949, Geology of Green and Yampa River Canyons and vicinity, Dinosaur National Monument, Utah and Colorado: Am. Assoc. Petroleum Geologists Bull., v. 33, no. 5, p. 683-694.

White, C.A., 1889, On the geology and physiography of a portion of northwestern Colorado and adjacent parts of Utah and Wyoming: U. S. Geol. Survey 9 th Ann. Rept., p. 677-712. Map, scale 1 in. to $13 \mathrm{mi}$.

\section{IDAHO}

* Anderson, A. L., 1931, Geology and mineral resources of eastern Cassia County, Idaho: Idaho Bur. Mines and Geology Bull. 14, p. 35-37, 96, 101-102, pls. 18, 19. Map, scale $1: 125,000$.

- 1952, Multiple emplacement of the Idaho batholith : Jour. Geol. v. 60, no. 3, p. 255-265.

Bell, R. N., 1901, An outline of Idaho geology and of the principal ore deposits of Lemhi and Custer Counties, Idaho: Internat. Min. Cong., 4th, Proc., p. 64-80.

Boardman, Leona, 1949, Geologic map index of Idaho: U. S. Geol. Survey. Scale, $1: 750,000$.

Breger, C. L., 1910, The salt resources of the Idaho-Wyoming border, with notes on the geology: U. S. Geol. Survey Bull. 430, p. 555-569. Map, scale 1 in. to $4 \mathrm{mi}$.

* Clabaugh, P. S., 1946, Permian phosphate deposits of Montana, Idaho, Wyoming, and Utah: U. S. Geol. Survey Strategic Minerals Inv. Prelim. Map 3-198. Scale $1: 1,000,000$.

*Condit, D. D., 1919, Oil shale in western Montana, southeastern Idaho, and adjacent parts of Wyoming and Utah: U. S. Geol. Survey Bull. 711, p. 15-40, 1920 ; abs., Wash. Acad. Sci. Jour. v. 9, p. 638.

* Douglass, Earl, 1909, A geological reconnaissance in North Dakota, Montana, and Idaho; with notes on Mesozoic and Cenozoic geology : Carnegie Mus. Annals, v. 5, p. 211-288.

* Gale, H. S., and Richards, R. W., 1910, Preliminary report on the phosphate deposits in southeastern Idaho and adjacent parts of Wyoming and Utah: U. S. Geol. Survey Bull. 430, p. 457-535. Maps, scale 1:62,500.

* Gardner, L S., 1944, Phosphate deposits of the Teton Basin area, Idaho and Wyoming: U. S. Geol. Survey Bull. 944-A, p. 1-36. Maps, scale 1: 48,000.

Flayden, F. V., 1883, Geologic maps of portions of Idaho, Wyoming, and Utah: U. S. Geol. Geog. Survey Terr. 12th Ann. Rept. Scales, $1: 500,000,1: 253,440$.

*Idaho University, Phosphate Committee, 1938, The University of Idaho and the development of Idaho phosphates [progress dept.] : Idaho Univ. Bull., v. 33 , no. 2. 
- Kirkham, V. R. D., 1922, Petroleum possibilities of certain anticlines in southeastern Idaho: Idaho Bur. Mines and Geology Bull. 4, 36 p. Maps, scale 1 in. to $1 \mathrm{mi}$.

- 1923, Notes on the geology of eastern Bear Lake County, Idaho, with reference to oil possibilities: Idaho Bur. Mines and Geology Pamph. 7, 6 p.

* 1924, Geology and oil possibilities of Bingham, Bonneville, and Caribon Counties, Idaho: Idaho Bur. Mines and Geology Bull. 8, 116 p. Maps, scale about 1 in. to $1 \%$ mi.

* 1925, Oil possibilities of southeastern Idaho: Mining and Metallurgy, v. 6, p. 71-74.

- 1925, Phosphate deposits of Idaho and their relation to the world supply : Am. Inst. Min. Metall. Eng. Trans. [prepr.], no. 1405, 28 p.; [with discussion], Trans., v. 71, p. 308-338, 1925. Also published as Repr. 1, Idaho Bur. Mines and Geology, 1925.

* 1927, A geologic reconnaissance of Clark and Jefferson and parts of Butte, Custer, Fremont, Lemhi, and Madison Counties, Idaho: Idaho Bur. Mines and Geology Pamph. 19, p. 20-21, 42. Map, scale 1 in. to about 63/4 mi.

- Mansfield, G. R., 1916, Geologic map of the Fort Hall Indian Reservation [abs.] : Geol. Soc. America Bull. 27, p. 64.

* 1916, Preliminary geologic map of Wayan quadrangle, Idaho-Wyo. [abs.] : Geol. Soc. America Bull. 27, p. 65.

- 1920, Geography, geology and mineral resources of the Fort Hall Indian Reservation, Idaho, with a chapter on water resources by W. B. Heroy: U. S. Geol. Survey Bull. 713, 152 p. Map, scale 1 : 125,000.

* 1920, Coal in eastern Idaho: U. S. Geol. Survey Bull. 716, p. 123-153; abs., Wash. Acad. Sci. Jour., v. 11, no. 8, p. 193, 1921. Map, scale 1 in. to 2 mi.

*_ 1921, Igneous geology of southeastern Idaho: Geol. Soc. America Bull., v. 32, p. 249-266. Map, scale 1 in. to $4 \mathrm{mi}$.

- 1927, Geography, geology, and mineral resources of part of southeastern Idaho: U. S. Geol. Survey Prof. Paper 152, p. 1-409. Maps, various scales.

1927, Summary of the geology of southeastern Idaho with notes on recent work [abs.] : Wash. Acad. Sci. Jour., v. 17, p. 129-130.

*__ 1929, Geography, geology, and mineral resources of the Portneuf quadrangle, Idaho: U. S. Geol. Survey Bull. 803,110 p. Map, scale 1 in. to $1 \mathrm{mi}$.

Palmer, J. T., 1931, Outline of the geology of Idaho: Geog. Soc. Philadelphia Bull., v. 29, no. 4, p. 55-61 (299-305).

*Pardee, J. T., 1917, The Dunkleberg mining district, Granite County, Mont.: U. S. Geol. Survey Bull. 660, p. 242-247, map; abs., Wash. Acad. Sci. Jour., v. 8, p. 249.

*Richards, R. W., and Bridges, J. H., 1911, Sulfur deposits near Soda Springs, Idaho: U. S. Geol. Survey Bull. 470, pt. 1, p. 499, fig. 58. Map, scale 1 in. to $31 / 2 \mathrm{mi}$.

*Richards, R. W., and Mansfield, G. R., 1911, Preliminary report on a portion of the Idaho phosphate reserve: U. S. Geol. Survey Bull. 470, p. 371-439. Maps, scale 1 in. to $1 \mathrm{mi}$. and $1 \mathrm{in}$. to $71 / 2 \mathrm{mi}$.

*__ 1914, Geology of the phosphate deposits northeast of Georgetown, Idaho : U. S. Geol. Survey Bull. 577. Maps, scales 1 in. to $1 \mathrm{mi}$. and 1 in. to $4 \mathrm{mi}$.

Ross, C. P., 1928, Salient features of geology of south-central Idaho [abs.] : Wash. Acad. Sci. Jour., v. 18, p. 267-268.

*Ross, C. P., and Forrester, J. D., 1946, Geological map of the State of Idaho: U. S. Geol: Survey, 1947. Scale 1: 500,000; abs., Wash. Acad. Sci. Jour., v. 30, no. 4, p. 135.

Russell, I. C., 1902, Geology and water resources of the Snake River plains of Idaho : U. S. Geol. Survey Bull. 199, 192 p. 
*Schultz, A. R., 1918, A geologic reconnaissance for phosphate and coal in southeastern Idaho and western Wyo. U. S. Geol. Survey Bull. 680, 84 p. Maps, various scales.

Schultz, A. R., and Richards, R. W., 1913, A geologic reconnaissance in southeastern Idaho: U. S. Geol. Survey Bull. 530, p. 267-284. Map, scale 1 in. to $7 \frac{1}{2} \mathrm{mf}$.

United States Geological and Geographical Survey of the Territories, 1878, Atlas. Maps, geologic and geographic, various scales.

*Weeks, F. B., and Ferrier, W. F., 1907, Phosphate deposits in western United States: U. S. Geol. Survey Bull. 315, p. 449-462; abs., Science, new ser., v. 25, p. 620-621. Map, scale 1 in. to $16 \mathrm{mi}$.

Weeks, F. B., and Heikes, V. C., 1908, Notes on the Fort Hall mining district, Idaho: U. S. Geol. Survey Bull. 340, p. 175-182.

\section{MONTANA}

Anderson, A. L., 1952, Multiple emplacement of the Idaho Batholith: Jour. Geology, v. 60, no. 3, p. 255-265.

*Andrews, D. A., Lambert, G. S., and Stose, G. W., 1944, Geologic map of Montana: U. S. Geol. Survey Oil and Gas Inv. Prelim. Map 25, 2 sheets. Scale $1: 500,000$.

*Berry, G. W., 1943, Stratigraphy and structure at Three Forks, Mont.: Geol. Soc. America Bull., v. 54, p. 1-29.' Map, scale 1 in. to $2 \mathrm{mi}$.

*Bevan, A. C., 1923, Summary of the geology of the Beartooth Mountains, Mont. : Jour. Geology, v. 31, p. 441-465. Map, scale 1 in. to $20 \mathrm{mi}$.

*Boardman, Leona, and Brown, Annabel, 1948, Geologic map index of Montana : U. S. Geol. Survey. Scale, $1 \mathrm{in}$. to about $12 \mathrm{mi}$.

*Calkins, F. C., and Emmons, W. H., 1915, Description of the Philipsburg quadrangle, Mont.: U. S. Geol. Survey Geol. Atlas, folio 196, p. 8, 25. Map, scale $1: 125,000$.

*Clabaugh, P. S., 1946, Permian phosphate deposits of Montana, Idaho, Wyoming, and Utah: U. S. Geol. Survey Strategic Minerals Inv. Prelim. Map 3-198. Scale $1: 1,000,000$.

*Clapp, C. H., 1932, Geology of a portion of the Rocky Mountains of northwestern Montana: Mont. Bur. Mines and Geology Mem. 4, 30 p. Map, scale 1 in. to about $7 \mathrm{mi}$.

*Clapp, C. H., Bevan, Arthur, and Lambert, G. S., 1921, Geology and oil and gas prospects of central and eastern Montana: Mont. Univ. Bull., Bur. Mines and Metallurgy, ser. 4, p. 1-69.

Cobban, W. A., 1945, Marine Jurassic formations of Sweetgrass Arch, Montana : Am. Assoc. Petroleum Geologists Bull., v. 29, p. 1262-1303.

- Condit, D. D., 1918, Relations of late Paleozoic and early Mesozoic formations of southwestern Montana and adjacent parts of Wyoming: U. S. Geol. Survey Prof. Paper 120, p. 111-121; abs., Wash. Acad. Sci. Jour., v. 9, p. 530-531.

*Condit, D. D., Finch, E. H., and Pardee, J. T., 1928, Phosphate rock in the Three Forks-Yellowstone Park region, Mont.: U. S. Geol. Survey Bull. 795, p. 147-209.

* Douglass, Earl, 1905, Some notes on the geology of southwestern Montana : Carnegie Mus. Annals, v. 3, p. 407-428.

*___ 1909, A geological reconnaissance in North Dakota, Montana, and Idaho; with notes on Mesozoic and Cenozoic geology : Carnegie Mus. Annals, v. 5, p. 211-288. 
Emmons, S. F., and Tower, G. W., Jr., 1897, Economic geology of the Butte Special district: U. S. Geol. Survey Geol. Atlas, folio 38, p. 3-8. Map, scale $1: 15,000$.

Emmons, W. H., 1908, Geology of the Haystack stock, Cowles, Park County, Mont.: Jour. Geology, v. 16, p. 193-229. Map, scale 1 in. to about 21/4 mi.

*Emmons, W. H., and Calkins, F. C., 1913, Geology and ore deposits of the Philipsburg quadrangle, Mont.: U. S. Geol. Survey Prof. Paper 78, p. 70-74, 166. Map, scale $1: 125,000$.

- Field, R. M., and others, 1933, Yellowstone-Beartooth-Big Horn region: Internat. Geol. Cong., 16th sess., United States, 1933, Guidebook 24, Excursion C-2, 64 p. Maps, various scales.

- Gale, H. S., 1911, Rock phosphate near Melrose, Mont.: U. S. Geol. Survey Bull. 470 , p. $440-451$. Map, scale 1 in. to $7 \mathrm{mi}$.

- Goddard, E. N., 1940, Manganese deposits at Philipsburg, Granite County, Mont.-a preliminary report: U. S. Geol. Survey Bull. 922, p. 157-204. Map, scale $1 \mathrm{in}$. to $1,000 \mathrm{ft}$.

Griswold, L. S., 1898, The geology of Helena, Mont., and vicinity : Assoc. Eng. Soc. Jour., v. 20, p. 51-68.

Horberg, Leland, 1940, Geomorphic problems and glacial geology of the Yellowstone Valley, Park County, Mont.: Jour. Geology, v. 48, p. 275-303. Maps, scales 1 in. to $20 \mathrm{mi} ., 1 \mathrm{in}$. to $5 \mathrm{mi}$., 1 in. to $2 \frac{1}{2} \mathrm{mi}$.

*Iddings, J. P., 1896, Igneous rocks, in Description of Yellowstone National Park: U. S. Geol. Survey Geol. Atlas, folio 30. Maps, scale 1: 125,000.

Iddings, J. P., and Weed, W. H., 1894, Description of Livingston quadrangle [Mont.] : U. S. Geol. Survey Geol. Atlas, folio 1. Maps, scale 1: 250,000.

* Karlstrom, T. N. V., 1948, Geology and ore deposits of the Hecla mining district, Beaverhead County, Mont.: Mont. Bur. Mines and Geology Mem. 25, $87 \mathrm{p}$. Maps, scales 1 in. to $1,000 \mathrm{ft}$., 1 in. to $1 / 2 \mathrm{mi}$.

- Knappen, R. S., and Moulton, G. F., 1930, Geology and mineral resources of parts of Carbon, Big Horn, Yellowstone, and Stillwater Counties, Mont.: U. S. Geol. Survey Bull. 822, p. 14, pl. 2. Map, scale $1: 125,000$.

- Knopf, Adolph, 1913, Ore deposits of the Helena mining region, Mont.: U. S. Geol. Survey Bull. 527, p. 22. Map, scale 1 : $250,000$.

* Lovering, T. S., 1929, The New World or Cooke City mining district, Park County, Mont.: U. S. Geol. Survey Bull., 811, p. 1-87, pl. 6. Map, scale $1: 31,680$.

Miller, G. W., 1904, Geology of the Butte Mining district, Mont.: Ores and Metals, v. 13, no. 10, p. 15-16, no. 11, p. 19-20.

* Pardee, J. T., 1913, Some further discoveries of rock phosphate in Montana: U. S. Geol. Survey Bull. 530, p. 285-291. Map, scale 1 in. to $12 \mathrm{mi}$.

- 1917, The Garrison and Philipsburg phosphate fields, Montana : U. S. Geol. Survey Bull. 640, p. 195-228. Map, scale 1 : 125,000.

- 1921, Phosphate rock near Maxville, Granite County, Mont. : U. S. Geol. Survey Bull. 715, p. 141-145. Map, scale 1: 125,000.

* 1936, Phosphate rock near Maxville, Philipsburg, and Avon, Mont. : U. S. Geol. Survey Bull. 847, p. 175-188. Maps, scale 1 in. to 1 mi.

* Pardee, J. T., and Schrader, F. C., 1933, Metalliferous deposits of the greater Helena mining region, Montana: U. S. Geol. Survey Bull. 842, 318 p. Map, scale $1: 250,000$.

Peale, A. C., 1893, The Paleozoic section in the vicinity of Three Forks, Mont.:

U. S. Geol. Survey Bull. 110, p. 32-43. Map, scale $1: 250,000$.

1896, Description of the Three Forks sheet, [Mont.] : U. S. Geol. Survey

Geol. Atlas, folio 24; abs., Jour. Geology, v. 5, p. 407-409. Map, scale $1: 250,000$. 
Perry, E. S., 1932, The Butte mining district, Montana: Internat. Geol. Cong., 16th sess., United States, 1933, Guidebook 23, Excursion C-2, 25 p. Maps, various scales.

1934, Physiography and groundwater supply in the Big Hole Basin, Mont.: Mont. Bur. Mines and Geology Mem. 12, pl. 3 and explanation. Map, scale 1 in. to $8 \mathrm{mi}$.

- 1945, Distribution of sedimentary rocks in Montana and the northwestern Great Plains: Mont. Bur. Mines and Geology Misc. Contrib. 8, p. 8 and map facing, correlation chart.

* Pierce, W. G., Andrews, D. A., and Keroher, J. K., 1947, Structure contour map of the Big Horn Basin, Wyo. and Mont.: U. S. Geol. Survey Oil and Gas Inv. Prelim. Map 74. Scale 1 in. to about $3 \mathrm{mi}$.

* Reeves, Frank, 1924, Geology and possible oil and gas resources of the faulted area south of the Bearpaw Mountains, Mont.: U. S. Geol. Survey Bull. 751, p. 71-114, 5 pls. Map, scale 1:125,000.

* 1931, Geology of the Big Snowy Mountains: U. S. Geol. Survey Prof. Paper 165, p. 143. Map, scale 1 in. to $2 \mathrm{mi}$.

* Richards, R. W., and Pardee, J. T., 1925, The Melrose phosphate field, Montana : U. S. Geol. Survey Bull. 780, p. 1-32. Map, scale 1: 62,500.

* Rogers, C. P., Gardner, L. S., and Hadley, H. D., 1945, Thickness and general distribution of upper Paleozoic and lower Mesozoic rocks in south-central Montana : U. S. Geol. Survey Oil and Gas Inv. Prelim. Map 43. Scale 1 in. to $21 \mathrm{mi}$.

- Stone, R. W., and Bonine, C. A., 1914, The Elliston phosphate field, Montana: U. S. Geol. Survey Bull. 580, p. 373-383. Map, scale 1 in. to $1 \mathrm{mi}$.

Stow, M. H., 1952, Results of some heavy mineral studies in the Big Horn Basin, Mont. and Wyo., in Wyo. Geol. Assoc. Guidebook 7, p. 80-88.

* Tansley, Wilfred, Schafer, P. A., and Hart, L. H., 1933, A geological reconnaissance of the Tobacco Root Mountains, Madison County, Mont.: Mont. Bur. Mines and Geology Mem. 9, 57 p. Map, scale 1 in. to $2 \frac{1}{2} \mathrm{mi}$.

United States Geological and Geographical Survey of the Territories, 1878, Atlas. Maps, geologic and geographic, various scales.

* Wilson, C. W., Jr., 1934, Geology of the thrust fault near Gardiner, Mont.: Jour. Geology, v. 42, p. 649-663. Map, scale 1 in. to about 13/8 mi.

* Winchell, A. N., 1914, Mining districts of the Dillon quadrangle, Mont., and adjacent areas: U. S. Geol. Survey Bull. 574, p. 26, maps, various scales; abs., Wash. Acad. Sci. Jour., v. 5, p. 23.

* Wyoming University, Wyoming Geological Association, and Yellowstone-Bighorn Research Association, 1947. Guidebook, Field conference in the Bighorn basin, Aug. 5-8, 1947, $277 \mathrm{p}$.

\section{UTAH}

- Andrews, D. A., and Hunt, C. B., 1948, Geologic map of eastern and southern Utah: U. S. Geol. Survey Oil and Gas Inv. Prelim. Map 70. Scale 1: 500,000.

* Atwood, W. W., 1909, Glaciation of the Uinta and Wasatch Mountains: U. S. Geol. Survey Prof. Paper 61, p. 9-10, pl. 1 .

Bacon, C. S., Jr., 1948, Geology of the Confusion Range, west-central Utah: Geol. Soc. America Bull., v. 59, no. 10, p. 1027-1052. Maps, various scales.

* Bailey, R. W., 1927, A contribution to the geology of the Bear River Range, Utah: Chicago Univ. unpub. thesis, $23 \mathrm{p}$.

* Baker, A. A., 1946, Geology of the Green River Desert-Cataract Canyon Region, Emery, Wayne, and Garfield Counties, Utah: U. S. Geoi. Survey Bull. 95.1, p. $32-50$. 
*Baker, A. A., and others, 1947, Stratigraphy of the Wasatch Mountains in the vicinity of Provo, Utah: U. S. Geol. Survey Oil and Gas Inv. Prelim. Chart 30. Scale 1 in. to $5 \mathrm{mi}$.

Barb, C. F., 1944, Hydrocarbons of the Uinta Basin of Utah and Colorado. Review of geology and field work; with a section by Ball, J. O. Survey of bitumen analyses and extraction methods: Colo. School Mines Quart., v. 39, no. $1,115 \mathrm{p}$.

* Berkey, C. P., 1905, Stratigraphy of the Uinta Mountains: Geol. Soc. America Bull., v. 16, p. 517-530.

Bissell, H. J., 1952, Stratigraphy and structure of Northeast Strawberry Valley quadrangle, Utah: Am. Assoc. Petroleum Geologists Bull., v. 36, no. 4, p. 575.

* Blackwelder, Eliot, 1910, New light on the geology of the Wasatch Mountains, Utah : Geol. Soc. America Bull., v. 21, p. 517-542. Map, scale 1 in. to 2 mi.

* 1910, Phosphate deposits east of Ogden, Utah : U. S. Geol. Survey Bull. 430 , p. 536-551. Map, scale 1 in. to $8 \mathrm{mi}$.

* Boardman, Leona, and Brown, Annabel, 1948, Geologic map index of Utah: U. S. Geol. Survey. Scale, $1: 750,000$.

* Boutwell, J. M., with contributions by Woolsey, L. H., 1912, Geology and ore deposits of the Park City district, Utah: U. S. Geol. Survey Prof. Paper 77, p. 42, 49-52 ; abs., Wash. Acad. Sci. Jour., v. 3, p. 445-447, 1913. Map, scale $1: 25,000$.

*Boutwell, J. M., and others, 1933, The Salt Lake region: Internat. Geol. Cong., 16th sess., United States, 1933, Guidebook 17, Excursion C-1, 149 p. Maps, various scales.

* Butler, B. S., and Loughlin, G. F., 1915, A reconnaissance of the CottonwooaAmerican Fork mining region, Utah: U. S. Geol. Survey Bull. 620 , p. 174. Map, scale 1: 50,000 .

* Butler, B. S., Loughlin, G. F., Heikes, V. C., and others, 1920, The ore deposits of Utah: U. S. Geol. Survey Prof. Paper 111, p. 295, 642, pl. 56. Maps, various scales.

* Calkins, F. C., and Butler, B. S., 1943, Geology and ore deposits of the Cottonwood-American Fork area, Utah, with sections on history and production by V. C. Heikes: U. S. Geol. Survey Prof. Paper 201, p. 22, 30-31, 89. Map, scale $1: 250,000$.

*Clabaugh, P. S., 1946, Permian phosphate deposits of Montana, Idaho, Wyoming, and Utah: U. S. Geol. Survey, Strategic Minerals Inv. Prelim, Map 3-198. Scale $1: 1,000,000$.

* Condit, D. D., 1920, Oil shale in western Montana, southeastern Idaho, and adjacent parts of Wyoming and Utah: U. S. Geol. Surrey Bull. 711, p. $15-40$; abs., Wash. Acad. Sci. Jour., v. 9, p. 638.

* Eardley, A. J., 1934, Structure and physiography of the southern Wasatch Mountains, Utah: Mich. Acad. Scl, Papers, V. 19, p. 377-400; abs., Geor. Soc. America Bull., v. 44, pt. 1, p. 83-84.

- 1944, Geology of the north-central Wasatch Mountains, Utah: Geol. Soc. America Bull., v. 55, p. 819-894; abs., Utah Acad. Sci. Proc., v. 19-20, 1941-43, p. 19. Maps, scale 1 in. to $2 \mathrm{mi}$., and 1 in. to $1 \mathrm{mi}$.

* Forrester, J. D., 1937, Structure of the Uinta Mountains: Geol. Soc. America Bull., v. 48, p. 631-666. Map, scale 1 in. to $9^{1 / 2} \mathrm{mi}$.

Gale, H. S., 1909, Coal fields of northwestern Colorado and northeastern Utah : U. S. Geol. Survey Bull. 341, p. 283-315. Maps, scale 1 in. $=4 \mathrm{mi}$.

*Gale, H. S., and Richards, R. W., 1910, Preliminary report on the phosphate deposits in southeastern Idaho and adjacent parts of Wyoming and Utah: U. S. Geol. Survey Bull. 430, p, 457-535. Maps, scale 1:62,500. 
* Gilluly, James, 1929, Geology and oil and gas prospects of part of the San Rafael Swell, Utah: U. S. Geol. Survey Bull. 806, p. 69-130.

Gilliland, W. N., 1952, Another Tertiary crustal disturbance in central Utah: Am. Assoc. Petroleum Geologists Bull. v. 36, no. 7, p. 1461-1464.

* Hanson, A. M., 1942, Phosphate deposits in western Summit, Wasatch, Salt Lake, Morgan, and Weber Counties, Utah: Utah Agr. Coll., Logan, Utah, unpub. thesis.

Hayden, F. V., 1883, Geologic maps of portions of Idaho, Wyoming, and Utah: U. S. Geol. Geog. Survey Terr. 12th Ann. Rept. Scales 1: 500,000, 1: 253,440.

* Hintze, F. F., 1913, A contribution to the geology of the Wasatch Mountains, Utah: N. Y. Acad. Sci. Annals, v. 23, p. 85-143.

"Howard, L. O., 1916, Geology of the Cottonwood districts: Min. Sci. Press, v. 112, p. 557-562. Map, no scale given.

* Huddle, J. W., and McCann, F. T., 1947, Geologic map of Duchesne River area, Wasatch and Duchesne Counties, Utah: U. S. Geol. Survey Oil and Gas Inv. Prelim. Map 75. Scale 1 in. to $1 \mathrm{mi}$.

* Kay, J. L., 1934, The Tertiary formations of the Uinta Basin, Utah : Carnegie Mus. Annals, v. 23, p. 357-372. Map, scale 1 in. to $8 \mathrm{mi}$.

Kinney, D. M., 1951, Geology of the Uinta River and Brush Creek-Diamond Mountain areas, Duchesne and Uintah Counties, Utah: U. S. Geol. Survey Oil and Gas Inv. Map OM 123. Scale, $1: 63,360$.

*Kinney, D. M., and Rominger, J. F., 1947, Geology of the Whiterocks River-Ashley Creek area, Uintah County, Utah: U. S. Geol. Survey Oil and Gas Inv. Prelim. Map S2. Scale 1 in. to $1 \mathrm{mi}$.

${ }^{*}$ Larrabee, D. M., Clabaugh, S. E., and Dow, D. H., 1945, Mineral resources of the Missouri Valley region; pt. 2, Nonmetallic mineral resources: U. S. Geol. Survey Missouri Basin Studies Map. 1, pt. 2. Scale 1:2,500,000, or 1 in. to about $40 \mathrm{mi}$.

Lupton, C. T., 1912, The deep Creek district of the Vernal coal field, Uinta County, Utah : U. S. Geol. Survey Bull. 471, p. 579-594.

*Nolan, T. B., 1935, The Gold Hill Mining district, Utah : U. S. Geol. Survey Prof. Paper 177, p. 39-42. Maps, scales 1: 24,000, $1: 62,500$.

Pack, F. J., 1919, Wonders of Utah geology : Utah Univ. Bull., v. 10, no. 12, 24 p.

*Reeside, J. B., Jr., 1923, Notes on the geology of Green River between Green River, Wyoming, and Green River, Utah: U. S. Geol. Survey Prof. Paper 132 , p. 35-50.

*Richardson, G. B., 1941, Geology and mineral resources of the Randolph quadrangle, Utah-Wyoming: U. S. Geol. Survey Bull. 923, 55 p. Map, scale $1: 125,000$.

*Schneider, Hyrum, 1919, General geology of Utah: Utah Univ. Bull., v. 10, no. 11 (Eng. Sta., Dept. Metall. Research Bull. 12), p. 3-33.

*Schultz, A R., 1918, A geologic reconnaissance of the Uinta Mountains, northern Utah, with special reference to phosphate: U. S. Geol. Survey Bull. 690, p. 31-94. Maps, scales 1 in. to $7 \mathrm{mi}$., 1 in. to $24 \mathrm{mi}$.

Talmadge, J. E. 1901, Geology of Utah : Internat. Min. Cong., 4th, Proc., p. 42-48.

United States Geological and Geographical Survey of the Territories, 1878, General geologic map of Colorado, surveyed in 1873-76; U. S. Geol. Geog. Survey Terr. Atlas. Maps, geologic and geographic, various scales.

*Untermann, G. E., and Untermann, B. R., 1949, Geology of Green and Yamp River Canyons and vicinity, Dinosaur National Monument, Utah and Colo.: Am. Assoc. Petroleum Geologists Bull., v. 33, p. 683-694.

"Walton, P. T., 1944, Geology of the Cretaceous of the Uinta Basin, Utah : Geol. Soc. America Bull., v. 55, p. 91-130. Map, scale 1 in. to $81 / 2 \mathrm{mi}$.

$296348-54-2$ 
Weed, W. H., 1912, Geology and ore deposits of the Butte district, Mont. : U. S. Geol. Survey Prof. Paper 74, 262 p., pl. 1 ; abs., Wash. Acad. Sci. Jour., v. 3, p. 363-364, 1913. Map, scale 1: 15,000.

*Weeks, F. B., 1907, Stratigraphy and structure of the Uinta Range: Geol. Soc. America Bull., v. 18, p. 427-448. Map, scale 1 in. to $16 \mathrm{mi}$.

"Weeks, F. B., and Ferrier, W. F., 1906, Phosphate deposits in western United States : U. S. Geol. Survey Bull. 315, p. 449-462; abs., Science, new ser., v. 25, p. $620-621,1907$. Map, scale 1 in. to $16 \mathrm{mi}$.

White, C. A., 1889, On the geology and physiography of a portion of northwestern Colorado and adjacent parts of Utah and Wyoming: U. S. Geol. Survey 9th Ann. Rept., p. 677-717. Map, scale 1 in. to $13 \mathrm{mi}$.

*Williams, J. Stewart, 1939, Phosphate in Utah : Utah Agr. Exper. Sta. Bull. 290, $44 \mathrm{p.}$ Maps, scale ap. 1 in. to about $2 \mathrm{mi}$.

*Williams, J. Stewart, and Hanson, A. M., 1942, Phosphate reserves of Utah (revised estimate) : Utah Agr. Exper. Sta. Bull. 304 [supp. to Bull 290], $23 \mathrm{p}$. Maps, scales in. to about $61 / 2$ and $7 \frac{1}{2} \mathrm{mi}$.

\section{WYOMING}

*Andrews, D. A., 1944, Oil and gas in the Maverick Springs area, Fremont County, Wyo.: U. S. Geol. Survey Oil and Gas Inv. Prelim. Map 13. Scale, 1 in. to $3 / 4 \mathrm{mi}$.

*Barnett, V. H., 1914, The Douglas oil and gas field, Converse County, Wyo..: U. S. Geol. Survey Bull. 541, p. 54-58.

* Bauer, C. M., 1933, Wind River Basin, Wyo.: Geol. Soc. America Bull., v. 45, no. 4 , p. $665-696,1934$; abs., v. 44 , p. 71-72. Map, scale 1 in. to $4 \mathrm{mi}$.

Bertagnolli, A. J., Jr., 1941, Geology of southern part of La Barge region, Lincoln County, Wyo.: Am. Assoc. Petroleum Geologists Bull., v. 25, p. 1729-1744. Map, scale 1 in. to $1 \frac{1}{4} \mathrm{mi}$.

- Bevan, A. C., 1923, Summary of the geology of the Beartooth Mountains, Mont.: Jour. Geology, v. 31, p. 441-465. Map, scale 1 in. to $20 \mathrm{mi}$.

* Blackwelder, Eliot, 1911, A reconnaissance of the phosphate deposits in western Wyoming: U. S. Geol. Survey Bull. 470, p. 452-481. Map, scale $1: 1,000,000$.

* Boardman, Leona, 1947, Geologic map index of Wyoming: U. S. Geol. Survey. Scale $1: 750,000$.

Bradley, F. H., 1873, Report of the geologist of the Snake River region: U. S. Geol. Survey Terr. (Hayden) Ann. Rept. 6, p. 189-271. Small-scale geographic maps.

Bradley, W. F., 1945, Geology of the Washakie Basin, Sweetwater and Carbon Counties, Wyo., and Molfat County, Colo.: U. s. Geol. Survey Oil and Gas Inv. Prelim. Map 32. Scale, 1 in. to $3 \mathrm{mi}$.

* Branson, C. C., 1939, Pennsylvanian formations of Central Wyoming: Geol. Soc. America Bull.; v. 50, p. 1199-1225.

* Branson, E. B., and Branson, C. C., 1940, Geology of Wind River Mountains, Wyo.: Am. Ass0c. Petroleum Geologists Bull., v. 25, p. 120-151; abs., Oil and Gas. Jour., v. 38, no. 48, p. 55. Map, scale 1 in. to about $7 \mathrm{mi}$.

Berger, C. L., 1910, The salt resources of the Idaho-Wyoming border; with notes on the geology: U. S. Geol. Survey Bull. 430, p. 555-569. Map, scale 1. in. to $4 \mathrm{mi}$.

Campbell, M. R., and others, 1925, Geologic map of Wyoming: U. S. Geol. Survey. Scale $1: 500,000$. 
Clabaugh, P. S., 1946, Permian phosphate deposits of Montana, Idaho, Wyoming, and Utah: U. S. Geol. Survey' Strategic Minerals Inv. Prelim. Map 3-198. Scale $1: 1,000,000$.

Comstock, T. B., 1874, Geological report, in Jones, W. A., Report upon the reconnaissance of northwestern Wyoming; Cong. Doc., 43d Cong., 1st sess., H. Exec. Doc. 285, p. 85-184; additional chaps. in later ed. p. 85-292. Map, scale $1: 600,000$.

* Condit, D. D., 1916, Relations of the Embar and Chugwater formations in central Wyoming: U. S. Geol. Survey Prof. Paper 98, p. 263-270; abs., Wash. Acad. Sci. Jour., v. 7, p. 162, 1917.

- 1918, Relations of late Paleozoic and early Mesozoic formations of southwestern Montana and adjacent parts of Wyoming: U. S. Geol. Survey Prof. Paper 120, p. 111-121; abs., Wash. Acad. Sci. Jour., v. 9, p. 530-531, 1919.

* 1919, Oil shale in western Montana, southeastern Idaho, and adjacent parts of Wyoming and Utah: U. S. Geol. Survey Bull. 711, p. 15-40, 1920 ; abs., Wash. Acad. Sci. Jour., v. 9, p. 638.

* 1 1924, Phosphate deposits in the Wind River Mountains, near Lander, Wyo.: U. S. Geol. Survey Bull. 764, 39 p. Map, scale 1:125,500.

* Finch, E. H., and Pardee, J. T., 1928, Phosphate rock in the Three Forks-Yellowstone Park region, Mont. : U. S. Geol. Survey Bull. 795, p. 147209.

*Condit, D. D., and Lupton, C. T., 1916, Gypsum in the southern part of the Bighorn Mountains, Wyo.: U. S. Geol. Survey Bull. 640, p. 143-146; abs., Wash. Acad. Sci. Jour., v. 7, p. 78, 1917.

- Darton, N. H., 1906, Fish remains in Ordovician rocks in the Bighorn Mountains, Wyo., with a resume of Ordovician geology of the Northwest: Geol. Soc. Arnerica Bull., v. 17 p: 541-566. Map, scale 1 in. to about 20 mi.

*—1 1906, Geology of the Bighorn Mountains : U. S. Geol. Survey Prof. Paper 51 , p. 35-36. Map, scale 1 in. to $4 \mathrm{mi}$.

* 1906, Geology of the Owl Creek Mountains : Cong. Doc., 59th Cong., 1st sess., S. Doc. 219, p. 17-18, 31-32. Map, scale 1 in. to $4 \mathrm{mi}$.

*_ 1906, Description of the Bald Mountain and Dayton quadrangles, Wyo.; U. S. Geol. Survey Geol. Atlas, folio 141, map, structure section. Map, scale $1: 125,000$.

* - 1906, Description of Cloud Peak and Fort McKinney quadrangles, Wyo. : U. S. Geol. Survey Geol. Atlas, folio 142, map, stratigraphic section. Map, scale $1: 125,000$.

* - 1908, Paleozoic and Mesozoic of central Wyoming: Geol. Soc. America Bull., v. 19, p. $403-474$. Map, scale 1 in. to $20 \mathrm{mi}$.

*Darton, N. H., Blackwelder, Eliot, and Siebenthal, C. E., 1910, Description of the Laramie and Sherman quadrangles, Wyo.: U. S. Geol. Survey Geol. Atlas, folio 173. Map, scale $1: 125,000$.

Darton, N. H., and Siebenthal, C. E., 1909, Geology and mineral resources of the Laramie Basin, Wyo.: U. S. Geol. Survey Bull, 364, 88 p. Map, scale 1 in. to $1 \frac{1}{2} \mathrm{mi}$.

* Dobbin, C. E., Bowen, C. F., and Hoots, H. W., 1929, Geology and coal and oil resources of the Hanna and Carbon basins, Carbon County, Wyo. : U. S. Geol. Survey Bull. 804, p. 11-12. Map, scale 1: 65,000.

*Dobbin, C. E., Hoots, H. W., and Dane, C. H., 1928, Geology and oil and gas possibilities of the Bell Springs district, Carbon County, Wyo.: U. S. Geol. Survey Bull. 796, p. 177-178. 
"Dobbin, C. E., and others, 1929, Geology of the Rock Creek oil field and adjacent areas, Carbon and Albany Counties, Wyo.: U. S. Geol. Survey Bull. 806, p. 136-137. Map, scale $1: 63,360$.

Dorr, J. A., Jr., 1952, Early Cenozoic stratigraphy and vertebrate paleontology of the Hoback Basin, Wyo.: Geol. Soc. America Bull., v. 63, no. 1, p. 59-94.

* Edmund, R. W., 1940, Structural geology and physiography of the northern end of the Teton Mountains, Wyo. : Iowa Univ. unpub. dissert., 163 p.; abs., Iowa. Univ. Publ. Aims and Prog. Research Ser., no. 66, 1 p. Map, scale 1 in. to. $2 \mathrm{mi}$.

Eldridge, G. H., 1894, A geological reconnaissance in northwest Wyoming: U. S. Geol. Survey Bull. 119, 72 p. Map, scale 1 in. to $11 \frac{1}{2} \mathrm{mi}$.

* Fanshawe, J. R., 2d., 1939, Structural geology of Wind River Canyon area, Wyoming: Am. Assoc. Petroleum Geologists Bull., v. 23, p. 1439-1492. Map, scale $1 \mathrm{in}$. to about $1 \frac{1}{2} \mathrm{mi}$.

* Fath, A. E., and Moulton, G. F., 1924, Oil and gas fields of the Lost SoldierFerris district, Wyoming: U. S. Geol. Survey Bull. 756, 57 p. Maps, scales $1: 15,840,1: 125,000$.

* Field, R. M., and others, 1932, Yellowstone-Beartooth-Big Horn region: Internat. Geol. Cong., 16th sess., United States, 1933, Guidebook 24, Excursion C-2, 64 p. Maps, various scales.

- Fisher, C. A., 1906, Geology and water resources of the Bighorn Basin, Wyo. : U. S. Geol. Survey Prof. Paper 53, p. 17-18. Map, scale 1 in. to $4 \mathrm{mi}$.

Fryxell, F. M., 1944, The geology of Jackson Hole, Wyo.: Nat. Parks Assoc., Washington, D. C., $11 \mathrm{p}$.

* Gale, H. S., and Richards, R. W., 1910, Preliminary report on the phosphate deposits in southeastern Idaho and adjacent parts of Wyoming aud Utah: U. S. Geol. Survey Bull. 430, p. 457-535. Maps, scale 1 : 62,500.

* Gardner, L. S., 1944, Phosphate deposits of the Teton Basin area, Idaho and Wyoming: U. S. Geol. Survey Bull. 944, 36 p. Maps, scale 1: 48,000.

- Hague, Arnold, and others, 1899, Geology of the Yellowstone National Park: U. S. Geol. Survey Mon. 32, pt. 2, Descriptive geology, petrography, and paleontology, $893 \mathrm{p}$. Maps, various scales.

Hague, Arnold, Weed, W. H., and Iddings, J. P., 1896, Yellowstone National Park, Wyo.: U. S. Geol. Survey Geol. Atlas, folio 30. Map, scale 1:125,000.

- Hares, C. J., 1916, Anticlines in central Wyoming: U. S. Geol. Survey Bull. 641. p. 243.

* Hares, C. J., and others, 1946, Geologic map of the southeastern part of the Wind River basin and adjacent areas in central Wyoming: U. S. Geol. Survey Oil and Gas Inv. Prelim. Map 51 . Scale 1 in. to 2 mi.

* 1946, Geologic map of the southern part of the Wind River basin and adjacent areas in central Wyoming: U. S. Geol. Survey Oil and Gas Inv. Prelim. Map 60. Scale 1 in. to $3 \mathrm{mi}$.

Hayden, F. V., 1883, Geologic maps of portions of Idaho, Wyoming, and Utah : U. S. Geol. Geog. Survey Terr. 12th Ann. Rept. Scales, 1 : 500,000, $1: 253,440$.

* Heaton, R. L., 1933, Ancestral Rockies and Mesozoic and late Paleozoic stratigraphy of Rocky Mountain region: Am. Assoc. Petroleum Geologists Bull., v. 17, p. 109-124.

* Hewett, D. F., 1920, The Heart Mountain overthrust, Wyoming : Jour. Geology, v. 28, p. 536-557. Geologic sketch map.

* __ 1926, Geology and oil and coal resources of the Oregon Basin, Meeteetse, and Grass Greek Basin quadrangles, Wyo.: U. S. Geol. Survey Prof. Paper 145, p. 11. Maps, scale 1: 62,500. 
* Hewett, D. F., and Lupton, C. T., 1917, Anticlines in the southern part of the Big Horn Basin, Wyo.: U. S. Geol. Survey Bull. 656, p. 17-18. Map, scale 1: 500,000; abs., Wash. Acad. Sci. Jour., v. 8, p. 204-205, 1918.

Hughes, R. V., 1933, The geology of the Beartooth Mountain front in Park County, Wyo.: Natl. Acad. Sci. Proc., v. 19, no. 2, p. 239-253. Map, scale 1 in. to $4 \mathrm{mi}$.

- Jamison, C. E., 1911, Geology and mineral resources of a portion of Fremont County, Wyo.: Wyo. State Geologist's Office Bull. 2, ser. B, 90 p. Map, scale 1 in. $=2 \mathrm{mi}$.

* Johnson, G. D., 1934, Geology of the mountain uplift transsected by the Shoshone Canyon, Wyo. : Jour. Geology, v. 42, p. 815, 819. Map, scale 1:125,000.

* King, R. H., 1947, Phosphate deposits near Lander, Wyo.: Wyo. Geol. Survey Bull. 39, 84 p. Maps, scale 1 in. to $500 \mathrm{ft}$., and 1 in. to $2 \mathrm{mi}$.

* Knight, S. H., 1942-43, The genesis of the Late Paleozoic sediments of southeastern Wyoming [abs.] : Tulsa Geol. Soc. Digest, v. 11, p. 41-42.

* La Fleiche, Pierre, 1944, Geologic aspect of Wyoming and outlook for development [of oil and gas fields] : Oil and Gas Jour., v. 43, no. 13, p. 38, 41-42.

* 1945, Wyoming-Pt. 1, General geologic features: Oil Weekly, v. 118, no. 6, p. 30-33; Pt. 2, Oil and gas prospects, no. 8, p. 46-50. Maps, small scale.

- Love, J. D., 1934, The geology of the western end of the Owl Creek Mountains, Wyo.: Wyo. Geol. Survey Bull. 24, 25 p. Map, scale 1 in. to about $2 / 3 \mathrm{mi}$.

- 1939, Geology along the southern margin of the Absaroka Range, Wyo.: Geol. Soc. America Special Paper 20, p. 11-12, 31-38, pls. 8 and 17. Map, scale 1 in. to about $1 \frac{1}{4} \mathrm{mi}$.

- Love, J. D., and others, 1951, Geologic map of the Spread Creek-Gros Ventre River area, Teton County, Wyo.: U. S. Geol. Survey Oil and Gas Inv. Map OM 118. Scale 1 in. to $4,000 \mathrm{ft}$.

Love, J. D., and Weitz, J. L., 1951, Geologic map of the Powder River Basin, and adjacent areas: U. S. Geol. Survey Oil and Gas Inv. Map OM 122. Scale 1 in. to $5 \mathrm{mi}$.

- Mansfield, G. R., 1916, A reconnaisance for phosphate in the Salt River Range, Wyo.: U. S. Geol. Survey Bull. 620, p. 331-349. Map, scale 1: 62,500.

- 1916, Preliminary geologic map of Wayan quadrangle, Idaho-Wyo. [abs.] : Geol. Soc. America Bull. 27, p. 65.

- 1927, Geography, geology, and mineral resources of part of southeastern Idaho: U. S. Geol. Survey Prof. Paper 152, p. 1-409. Maps, various scales.

- Maravich, M. D., 1941, Geology of Freezeout Mountain-Bald Mountain area, Carbon County, Wyo.: Am. Assoc. Petroleum Geologists Bull., v. 25, p. 883-897. Map, scale 1 in to $1 \mathrm{mi}$.

* Morgan, G. B., 1921, Areal geology of Wyoming; correlation table and production data [on reverse of geological map of Wyoming] : 3d. ed. Cheyenne, Wyo., G. B. Morgan, State Geologist, and C. S. Hill, Commissioner of Immigration. Scale $1 \mathrm{in}$. to $18 \mathrm{mi}$.

- Neely, Joseph; 1934, The geology of the north end of the Medicine Bow Mountains, Carbon County, Wyo.: Wyo. Geol. Survey Bull. 25, 15 p. Map, scale 1 in. to $11 / 2 \mathrm{mi}$.

- Nelson, V. E., and Church, Victor, 1943, Critical structures of the Gros Ventre and northern Hoback Ranges, Wyo.: Jour. Geology, v. 51, p. 143-166. Maps, scale 1 in. to $4 \frac{1}{2} \mathrm{mi}$.

* Pierce, W. G., 1948, Geologic and structure-contour map of the Basin-Greybull area, Big Horn County, Wyo.: U. S. Geol. Survey Oil and Gas Inv. Prelim. Map 77. Scale 1 in to about $4 / 5 \mathrm{mi}$. 
* Pierce, W. G., and Andrews, D. A., 1941, Geology and coal resources of the region south of Cody, Park County, Wyo.: U. S. Geol. Survey Bull. 921-B, p. 110, 160. Map; scale 1: 63,360.

* Richardson, G. B., 1941, Geology and mineral resources of the Randolph quadrangle, Utah-Wyo.: U. S. Geol. Survey Bull. 923. Map; scale, 1:125,000.

* Richmond, G. M., 1945, Geology of northwest end of Wind River Mountains, Sublette County, Wyo.: U. S. Geol. Survey Oil and Gas Inv. Prelim. Map 31. Scale $1 \mathrm{in}$. to $1 \mathrm{mi}$.

* Rogers, C. P., Jr., and others, 1948, Geology of the Worland-Hyattville area, Big Horn and Washakie Counties, Wyo.: U. S. Geol. Survey Oil and Gas Inv. Prelim. Map 84. Scale 1 .in. to about $4 / 5 \mathrm{mi}$.

* Schultz, A. R., 1914, Geology and geography of a portion of Lincoln County, Wyo.: U. S. Geol. Survey Bull. 543, p. 42-45, 131-134. Map, scale 1: 125,000.

* 1918, A geologic reconnaisance for phosphate and coal in southeastern Idaho and.western Wyoming: U. S. Geol. Survey Bull. 680. Maps, various scales.

* Sears, J. D., 1924, Geology and oil and gas prospects of part of Moffat County, Colo., and southern Sweetwater County, Wyo.: U. S. Geol. Survey Bull. 751, p. 283-284. Map, scale 1 : 125,000.

Sharkey, H. H. R., Love, J. D., and Kirby, Jewell J., 1945, Map of Wyoming showing test wells for oil and gas, anticlinal axes, and oil and gas fields [dry holes in fields and producing wells are not shown]: U. S. Geol. Survey Oil and Gas Inv. Prelim. Map 19. Scale 1: 500,000.

* Sharkey, H. H. R., and others, 1946, Geologic and structure-contour map of Sage Creek Dome, Fremont County, Wyo.: U. S. Geol. Survey Oil and Gas Inv. Prelim. Map 53. Scale 1 in. to about $1 / 2 \mathrm{mi}$.

* Stipp, T. F., and French, H. F., 1944, Geologic and structure map of the Little Buffalo Basin oil and gas field and vicinity, Park and Hot Springs Counties, Wyo.: U. S. Geol. Survey. Scale 1 in. to $2 \mathrm{mi}$.

Stow, M. H., 1952, Results of some heavy mineral studies in the Big Horn Basin, Montana and Wyoming: Wyo. Geol. Assoc. Guidebook 7, p. 80-88.

* Swenson, F. A., 1942, Geology of the northwest flank of the Gros Ventre Mountains, Wyo: Iowa Univ. unpub. dissert., 100 p. ; abs., Iowa Univ. Pub., Aims and Progress Research Ser., no. 71, 1 p. Map, scale 1 in. to 13/7 mi.

Thomas, H. D., 1949, The geological history and geological structure of Wyoming: Wyo. Geol. Survey Bull. 42; 28 p.; abs., Regional stratigraphy and structure of Wyoming, Oil and Gas Jour., v. 46, p. 113, 1948.

* Tourtelot, H. A., and others, 1948, Geology of the Boysen area, central Wyoming: U. S. Geol. Survey Oil and Gas. Inv. Prelim. Map 91, 2 sheets. Scale, 1 in. to $3 / 4 \mathrm{mi}$.

United States Geological and Geographical Survey of the Territories, 1878. Atlas. Mans. geologic and geogranhic. various scales.

* Van Houten, F. B., 1950, Geology of the western part of the Beaver Divide area, Fremont County, Wyo.: U. S. Geol. Survey Oil and Gas Inv. Map OM 113. Scale, $1: 31,680$.

Veatch, A. C., 1906, Coal and oil in southern Uinta County, Wyo.: U. S. Geol. Survey Bull. 285, p. 331-353. Map, scale 1 in. to 5 mi.

* 1907, Geography and geology of a portion of southwestern Wyoming, with special reference to coal and oil: U. S. Geol. Survey Prof. Paper 56, p. 50 , chart facing p. 50 , pls. 4 and 5 . Map, scale $1: 125,000$.

Weart, R. C., 1947, Geology of the northern flank of the Wind River Mountains, Wyo. [abs.] : Geol. Soc. America Bull., v. 58, p. 1238-1239. 
* Weeks, F. B., and Ferrier, W. F., 1906, Phosphate deposits in western United States: U. S. Geol. Survey Bull. 315, p. 449-462. Abs., Science, new ser., v. 25, p. 620-621, 1907. Map, scale 1 in. to $16 \mathrm{mi}$.

White, C. A., 1889, On the geology and physiography of a portion of northwestern Colorado and adjacent parts of Utah and Wyoming: U. S. Geol. Survey 9 th Ann. Rept., p. 677-717. Map, scale 1 in. to $13 \mathrm{mi}$.

-Williams, M. D., and Sharkey, H. H. R., 1946, Geology of the Bargee area, Fremont County, Wyo.: U. S. Geol. Survey Oil and Gas Inv. Prelim. Map 56. Scale 1 in. to $2 \mathrm{mi}$.

* Woodruff, E. G., 1911, The Lander oil-field, Fremont County, Wyo.: U. S. Geol. Survey Bull. 452, p. 10-14. Map, scale $1: 63,360$.

Wortman, J. L., 1882, The geology of the Big Horn Basin: Am. Ph. Soc. Pr., . .20, p. 139-142.

*Wyoming University, Wyoming Geological Association, and Yellowstone-Bighorn Research Association, 1947, Guidebook, Field conference in the Bighorn Basin, Aug. 5-8, 277 p.

- Ziegler, Victor, 1916, The Pilot Butte oil field, Fremont County: Wyo. State Geologist's Office Bull. 13, p. 142-178. Map, scale 1 in. to about .4 mile.

\section{STRATIGRAPHY}

Adams, F. D., 1917, The phosphate discussion: Canadian Min. Jour., v. 38, p. 321-322.

*_ 1916, The extension of the Montana phosphate deposits northward into Canada: Natl. Acad. Sci. Proc., v. 2, p. 62-64; abs., (with discussion by L. D. Burling), Geol. Soc. America Bull., v. 27, p. 62.

*__ 1917, Discovery of phosphate of lime in the Rocky Mountains [with discussion by. W. F. Ferrier and L. D. Burling] : Canadian Min. Inst. Trans. v. 19, p. 321-348.

*Adams, F. D., and Dick, W. J., 1915, Discovery of prosphate of lime in the Rocky Mountains : 36 p., Canada Comm. Conservation.

Agatson, R. S., 1952, Tensleep formation of the Big Horn Basin: Wyo. Geol. Assoc. Guidebook 7, p. 44-48.

Alden, W. C., 1924, Physiographic development of the northern Great Plains: Geol. Soc. America Bull., v. 35, p. 385-423.

Amsden, T. W., and Miller, A. K., 1942, Ordovician conodonts from the Bighorn Mountains of Wyoming : Jour. Paleontology, v. 16, p. 301-306.

*Anderson, A. L., 1930, The geology and mineral resources of the region about Orofino, Idaho: Idaho Bur. Mines and Geology Pamph. 34, p. 13.

*__ 1931, Geology and mineral resources of eastern Cassia County, Idaho: Idaho Bur. Mines and Geology Bull. 14, 169 p. Map, scale 1 in. to $2 \mathrm{mi}$.

Anderson, A. L., and Kirkham, V. R. D., 1931, Alkaline rocks of the Highwood type in southeastern Idaho: Am. Jour. Sci., 5th ser., v. 22, p. 51-68.

*Andrews, D. A., 1944, Oil and gas in the Maverick Springs area, Fremont County, Wyo.: U. S. Geol. Survey Oil and Gas Inv. Prelim. Map 13. Scale 1 in. to $\% \mathrm{mi}$.

*Atwood, W. W., 1909, Glaciation of the Uinta and Wasatch Mountains: U. S. Geol: Survey Prof. Paper 61, p. 96, pl. 1.

*Bacon, C. S., Jr., 1941, Stratigraphy and structure of the Confusion and Conger Ranges, western Utah [abs.] : Geol. Soc. America Bull., v. 52, no. 12, pt. 2, p. 1994.

1947, Upper Paleozoic and Triassic from the Confusion Range, westcentral Utah [abs.]: Geol. Soc. America Bull., v. 58, no. 12, pt. 2, p. 1260.

* 1948, Geology of the Confusion Range, west-central Utah; Geol. Soc. America Bull., v. 59, p. 1027-1052. 
*Bailey, R. W., 1927, A contribution to the geology of the Bear River Range, Utah : Chicago Univ. unpub. thesis, p. 23.

*Baker, A. A., 1946, Geology of the Green River Desert-Cataract Canyon Region, Emery, Wayne, and Garfield Counties, Utah: U. S. Geol. Survey Bull. 951, p. 32-50.

*Baker, A. A., Bissell, H. L., and Bramlette, M. N., 1947, Stratigraphy of the Wasatch Mountains in the vicinity of Provo, Utah: U. S. Geol. Survey Oil and Gas Inv. Prelim. Chart 30.

*Baker, A. A., Huddle, J. W., and Kinney, D. M., 1949; Paleozoic geology of north and west sides of Uinta Basin, Utah: Am. Assoc. Petroleum Geologists Bull., v. 33, p. 1161-1197.

*Baker, A. A., and Williams, J. Steele, 1939, Permian in parts of Rocky Mountains and Colorado Plateau region: Am. Assoc. Petroleum Geologists Bull., v. 24, p. 617-636, 1940 ; abs., Oil Weekly, v. 93, no. 3, p. 70.

Baker, C. L.; 1946, Geology of the northwestern Wind River Mountains, Wyo. Geol. Soc. America Bull., v. 57, p. 565-596.

Baptist, O. C., Smith, W. R., Cordiner, F. S., and Sweeney, S. A., 1952, Physical properties of sands in the Frontier formation, Big Horn Basin, Wyo.: Wyo. Geol. Assoc. Guidebook 7, p. 67-73.

Barb, C. F., 1944, Hydrocarbons of the Uinta Basin of Utah and ColoradoReview of geology and field work; with section by Ball, J. O., Survey of bitumen analyses and extraction methods: Colo. School of Mines Quart., v. $39,115 \mathrm{p}$.

—_ 1946, Selected well $\operatorname{logs}$ of Colorado: Colo. School Mines Quart., v. 41, no. 1, $435 \mathrm{p}$.

*Barnett, V. H., 1914, The Douglas oil and gas field, Converse County, Wyo.; U. S. Geol. Survey Bull. 541, p. 54-58.

Bartlett, A. B., 1924, Twelfth biennial report of the State geologist [of Wyoming] : 41 p. Cheyenne, Wyo.

* Barton, H. E., 1948, Steamboat Butte oil field, Fremont County, Wyo.; in Structure of typical American oil fields: v. 3, p. 480-513, Am. Assoc. Petroleum Geologists.

* Bartram, J. G., 1926, Occurrence of black oil in Wyoming: Am. Assoc. Petroleum Geologists Bull., v. 10, p. 443-448.

* 1932, Character of producing sandstones and limestones of Wyoming and Montana: Am. Assoc. Petroleum Geologists Bull., v. 16, p. 870-873.

* Bass, N. W., 1946, Subsurface maps of the Rangely anticline, Rio Blanco County, Colo.: U. S. Geol. Survey Oil and Gas Inv. Prelim. Map 67, scale, 1 in. to $1 / 2 \mathrm{mi}$.

*Bass, N. W., and Northrup, S. A., 1950, South Canyon Creek dolomite member, a unit of Phosphoria age in Maroon formation near Glenwood Springs, Colo.: Am. Assoc. Petroleum Geologists Bull., v. 34, p. 1540-1551.

* Bauer, C. M., 1932, The geology of the southeastern part of the Wind River Basin, Wyo. [abs.] : Colo. Univ. Studies, v. 20, no. 1, p. 6-7 ; Colo. Univ. Bull., v. 32 , no. 15 .

* 1933, Wind River Basin, Wyo. : Geol. Soc. America Bull., v. 45, p. 665-696, 1934 ; abs., v. 44, p. 71-72. Map, scale 1 in. to 4 mi.

1940, Discussion, Geology along the southern margin of the Absaroka Range, Wyo. : Jour. Geology, v. 48, p. 324-327.

*Bauer, C. M., and Robinson, E. G., 1923, Comparatively stratigraphy in Montana: Am. Assoc. Petroleum Geologists Bull., v. 7, p. 159-178.

* Beck, Elfred, 1929, Salt Creek oil field, Natrona County, Wyo. : in Structure of typical American oil fields : v. 2, p. 589-603. Am. Assoc. Petroleum Geologists. 
Beecher, C. E., 1896, On the occurrence of Silurian strata in the Bighorn Mountains, Wyo., and in the Black Hills, S. Dak. : Am. Geologist, v. 18, p. 31-33.

Bell, R. N., Moore, F. C., and Campbell, Stuart, 1905-1921, Annual reports of the mining industry of Idaho, published each year. Boise.

Bell; W. C., 1940, Cambrian brachiopoda from Montana: Jour. Paleontology, v. 15, p. 193-255 ; 1941 abs., Geol. Soc. America Bull., v. 51; p. 1967, 1940.

* Bench, B. M., 1945, The Rangely oil and gas field and Uinta Basin [Rio Blanco County, Colo.] : Mines Mag.; v. 35, no. 10, p. 516-524, 532, 594, 596.

* Berkey, C. P., 1905, Stratigraphy of the Uinta Mountains: Geol. Soc. America Bull., v. 16, p. 517-530. Maps.

* Berry, G. W., 1943, Stratigraphy and structure at Three Forks; Mont.: Geol. Soc. America Bull., v. 54, p. 1-29. Map, scale 1 in. to 2 mi.

Bertagnolli, A. J., Jr., 1941, Geology of southern part of La Barge region, Lincoln County, Wyo.: Am. Assoc. Petroleum Geologists Bull., v. 25, p. 1729-1744. Map, scale 1 in. to $11 / 4 \mathrm{mi}$.

Bevan, Arthur, 1921, Some geologic features of the Beartooth Mountains, Mont. [abs.] : Geol. Soc. America Bull., v. 32, p. 29.

* 1 1923, Summary of the geology of the Beartooth Mountains, Mont.: Jour. Geology, v. 31, p. 441-465. Maps, scale 1 in to $20 \mathrm{mi}$.

Bissell, H. J., 1939, Fusulinids as an aid in zoning the Oquirrh series of Utah [abs.] : Utah Acad. Sci. Proc., v. 16, p. 87-89.

1939, The use of fusulinids in zoning the Utah Pennsylvania[n] strata [abs.] : Utah Acad. Sci. Proc., v. 16, p. 85 .

1952, Stratigraphy and structure of Northeast Strawberry Valley quadrangle, Utah: Am. Assoc. Petroleum Geologists Bull., v. 36, no. 4, p. 575.

Bissell, H. J., and Hansen, G. H., 1935, The Mississippian-Pennsylvanian contact in the central Wasatch Mountains, Utah: Utah Acad. Sci. Proc., v. 12, p. 163.

Blackstone, D. I., Jr., 1947, Montana and Wyoming examples of overthrusting in relation to petroleum accumulation [abs.]: Oil and Gas Jour., v. 45, no. 47, p. 116; Am. Assoc. Petroleum Geologists - Soc. Econ. Paleontologists and Mineralogists - Soc. Econ. Geologists Joint Ann. Mtg., Los Angeles, March 24-27, Program, p. 25.

* Blackwelder, Eliot, 1910, New light on the geology of the Wasatch Mountains, Utah: Geol. Soc: American Bull., v. 21, p. 517-542. Map, scale 1 in. to $8 \mathrm{mi}$.

- 1911, A reconnaissance of the phosphate deposits in western Wyoming:

U. S. Geol. Survey Bull. 470, p. 452-481. Map, scale 1: 1,000,000.

1913, Origin of the Bighorn dolomite of Wyoming: Geol. Soc. America Bull. 24, p. 607-624.

* 1913, New or little known Paleozoic faunas from Wyoming and Idaho: Am. Jour, Sci. 4th Ser., v. 36, p. 174-179.

1915, A fully exposed reef of calcareous algae(?) in the Middle Cambrian of the Teton Mountains [Wyo.]: Am. Jour. Sci. 4th Ser., v. 39, p. 646-650.

- 1918, New geological formations in western Wyoming: Wash. Acad. Sci. Jour., v. 8, p. 417-426.

1925, Wasatch Mountains revisited [abs.] : Geol. Soc. Am. Bull., v. 36, p. 132-133, 1925 ; Pan-Am. Geologist, v. 43, p. 74-75.

1932, An ancient glacial formation in Utah: Jour. Geology, v. 40, p. 289304 ; abs., Pan-Am. Geologist, v. 71, p. 47, 1939.

1935, Summary of the pre-Cambrian rocks of Utah and Wyoming: Utah Acad. Sci. Proc., v. 12, p. 153-157.

1939, Pleistocene mammoths in Utah and vicinity : Am. Jour. Sci., v. 237, p. $890-894$. 
Boutwell, J. M., 1903, Progress report on the Park City mining district, Utah : U. S. Geol. Survey Bull. 213, p. 31-40.

* 1904, Progress report on the Park City mining district, Utah: U. S. Geol. Survey Bull. 225, p. 143.

*- 1907, Stratigraphy and structure of the Park City mining district, Utah : Jour. Geology, v. 15, p. 434-458.

* Boutwell, J. M., with contributions by Woolsey, L. H., 1912, Geology and ore deposits of the Park City district, Utah : U. S. Geol. Survey Prof. Paper 77, p. $42,49-50$; abs., Wash. Acad. Sci. Jour. v. 3, p. 445-447, 1913. Map, scale $1: 25,000$.

* Boutwell, J. M., and others, 1933, The Salt Lake region: Internat. Geol. Cong., 16th sess., United States, 1933, Guidebook 17, Excursion C-1, 149 p. Maps, various scales.

- Bowen, C. F., 1918, Phosphatic oil shale near Dell and Dillon, Beaverhead County, Mont.: U. S. Geol. Surves Bull. 661, p. 315-320; abs., Wash. Acad. Sci. Jour., v. 8, p. 248.

Bradley, F. H., 1873, Explorations of 1872-U. S. Geological Survey of the Territories, under Dr. F. V. Hayden; Snake River Division: Am. Jour. Sci., 3d Ser., v. 6, p. 194-207.

- 1873, Report of the geologist of the Snake River region: U. S. Geol. Survey Terr. Ann. Rept. 6, 1872, p. 180-271. Small-scale geographic maps.

* Bradley; W. H., 1935, Geology of Alcova Dam and reservoir sites, North Platte River, Natrona County, Wyo.: Econ. Geology, v. 30, p. 147-165. Maps; scales 1 in. to 2,000 ft., 1 in. to about $500 \mathrm{ft}$.

1945, Geology of the Washakie Basin, Sweetwater and. Carbon Counties, Wyo., and Moffat County, Colo: : U. S. Geol. Survey Oil and Gas Inv. Prelim. Map 32. Scale, 1 in. to $3 \mathrm{mi}$.

* Brainerd, A. E., 1940, Big Muddy field, Converse County, Wyo.: Kans. Geol. Soc. Guidebook 14, p. 148-149.

*Brainerd, A. E., and Keyte, I. A., 1927, Some problems of the Chugwater-Sundance contact in the Bighorn district of Wyoming: Am. Assoc. Petroleum Geologists Bull., v. 11, p. 747-752.

* Branson, C. C., 1930, Paleontology and stratigraphy of the Phosphoria formation: Mo. Univ. Studies, v. 5, no. 2, p. 1-99; abs., Chicago Univ. Abs. Theses, Sci. Ser., v. 7, p. 211-217, 1931.

- 1935, Tensleep formation [Pennsylvanian] of Wyoming [abs.]: Geol. Soc. America Proc. 1934, p. 367.

- —_ 1936, Carboniferous stratigraphy of Wyoming [abs.]: Geol. Soc. America Proc. 1935, p. 391-392.

- 1938, Permian foraminifera in Wyoming [abs..] : Geol. Soc. America Proc. 1937, p. 270.

- 1938, Problems of Carboniferous stratigraphy in Wyoming [abs.] : Geol. Soc. America Proc. 1937, p. 306.

- 1939, Pennsylvanian formations of central Wyoming: Geol. Soc. America Bull., v. 50, p. 1199-1225.

* Branson, E. B., 1916, The lower Embar of Wyoming and its fauna: Jour. Geology, v. 24, p. 639-664.

1026, Correlation of Mississippian section of Rocky Mountain States and

Mississippi Valley States [abs.] : Pan-Am. Geologist, v. 45. p. 248.

1930, Jurassic-Triassic contact in western Wyoming [abs.]: Geol. Soc.

America Bull., v. 41, p. 120-121; Pan-Am. Geologist, v. 53, p. 134.

1947, Triassic [Chugwater] footprints from Wyoming: Jour. Paleontology, จ. 21, p. 588-590. 
Branson, E. B., and Branson, C. C., 1934, Triassic-Jurassic contrict in central Wyoming [abs.] : Geol. Soc. America Proc. 1933, p. 366-367.

- 1941, Geology of Wind River Mountains, Wyo.: Am. Assoc. Petroleum Geologists Bull. 25, p. 120-151; abs., Oil and Gas Jour., v. 38, no. 48, p. 55, 1940. Map scale 1 in. to about $7 \mathrm{mi}$.

- 1945, Upper Triassic and overlying formations in central Wyoming [abs.] : Geol. Soc. America Bull., v. 56; no. 12, pt. 2, p. 1149.

Branson, E. B., and Greger,.D. K., 1917, Amsden formation of the east slope of the Wind River Mountains of Wyoming and its fauna: Geol. Soc. America Bull., v. 29, p. 309-326, 1918 ; abs:; v. 28, p. 170.

Branson, E. B., and Mehl, M. G., 1930, Primitive fishes from the Devonian of Utah and Wyoming [abs.] : Geol. Soc. America Bull., v. 41, p. 180.

1930, Webbed-foot record from the Pennsylvanian of Wyoming [abs.]: Geol. Soc. America Bull., v. 41 , p. 180 ; Pan-Am. Geologist, v. 53, p. 307-308. : 1930, Devonic fishes from Jefferson dolomite of Utah [abs.] : Pan-Am. Geologist, v. 53,p. 308.

1931, Fishes of the Jefferson formation of Utah: Jour. Geology, จ. 39, p. $509-531$.

1931, Fish remains of the western interior Triassic [abs.] : Geol. Soc. America Bull., v. 42, p. 330-331; Pan-Am. Geologist, v. 55, p. 238-239.

1932, Footprint records from the Paleozoic and Mesozoic of Missouri, Kansas, and Wyoming: Geol. Soc. America Bull., v. 43, p. 383-398; abs., v. 43, p. 284-285 ; Pan-Am. Geologist, v. 57, p. 160.

Breger, C. L., 1910, The salt resources of the Idaho-Wyoming border, with notes on the geology: U. S. Geol. Survey Bull. 430, p. 555-569. Map, scale 1 in. to $4 \mathrm{mi}$.

- Brill, K. G., Jr., 1944, Late Paleozoic stratigraphy, west-central and northwestern Colorado: Geol. Soc. America Bull., v. 55, p. 621-656.

Bryant, W. L., 1932, Lower Devonian fishes of Beartooth Butte, Wyo.: Am Philos. Soc. Proc., v. 71, no. 5, p. 225-254.

* Bucher, W. A., Chamberlain, R. T., and Thom, W. T., Jr., 1933, Results of structural research work in Beartooth-Big Horn region, Montana and Wyoming: Am. Assoc. Petroleum Geologists Bull., v. 17, p. 680-693.; abs., Geol. Soc. America Bull., v. 44, p. 75-77; Pan-Am. Geologist, v. 59, p. 233-234.

Burbank, W. S., and Lovering, T. S., 1933, Relation of stratigraphy, structure, and igneous activity to ore deposition of Colorado and southern.Wyoming; in Ore deposits of the Western States (Lindgren Volume), p. 272-315; Am. Inst. Min. Metall. Eng.

Burling, L. D., 1914, Early Cambrian stratigraphy in the North American Cordillera, with discussion of Albertella and related faunas: Canada Geol. Survey Mus. Bull. 2, p. 93-129.

Burma, B. H., and Anderson, I. J., 1940, Some features of the Squaw formation near Lander, Wyo. : Iowa Acad. Sci. Proc. 1939, v. 46, p. 233-242.

Butler, B. S., 1933, Summary, Pt. 1 of Ore deposits related to stratigraphic, structural, and igneous geology in the western United States, in Ore deposits of: the Western States (Lindgren Volume), p. 198-240: Am. Inst. Min. Met-

- all. Eng.

* Butler, B. S., and Loughlin, G. F., 1915, A reconnaissance of the CottonwoodAmerican Fork mining region, Utah: U. S. Geol. Survey Bull. 620, p. 174. Map, scale 1: 50.000 .

* Butler, B. S., and others, 1920, The ore deposits of Utah: U. S. Geol. Survey Prof. Paper 111, p. 295, 642, pl. 57. Maps, large and small scales.

* Calkins, F. C., 1945, Carboniferous and Mesozoic rocks of Big Cottonwood Canyon, Utah [abs.] : Geol. Soc. America Bull., v. 56, p. 1150-1151. 
* Calkins, F. C., and Butler, B. S., 1943, Geology and ore deposits of the Cottonwood-American Fork area, Utah, with sections on history and production by V. C. Heikes :- U. S. Geol. Survey Prof. Paper 201, p. 22, 30-31, 89.

* Calkins, F. C., and Emmons, W. H., 1915, Description of the Philipsburg quadrangle, Montana : U. S. Geol. Survey Geol. Atlas, folio 196, p. 8, 25, columnar section. Map, scale 1: 125,000.

* Campbell, M. R., and others, 1915, Guidebook of the western United States; Part A. The Northern Pacific Route with a side trip to Yellowstone Park': U. S. Geol. Survey Bull. 611, 212 p.

Carpenter, J. T., 1932, A tentative correlation of northwestern Tertiary strata : Northwest Sci., v. 6, no. 2, p. 54-65, 1932 ; abs., Pan-Am. Geologist, v. 58, p. 151.

Case, E. C., 1915, The Permo-Carboniferous redbeds of North America and their vertebrate fauna : Carnegie Inst. Wash. Pub. 207, p. 62-71.

* 1919, The environment of life in the late Paleozoic in North America ; a paleogeographic study: Carnegie Inst. Wash. Pub. 283, p. 113-136. 1936, A nothosaur from the Triassic of Wyoming: Mich. Univ. Mus. Paleontology Contr. v. 5, no. 1, p. 1-36.

Caster, K. E., 1942, A laotirid from the Upper Cambrian of Wyoming: Am. Jour. Sci., v. 240, no. 2, p. 104-112.

* Clapp, C. H., 1932, Geology of a portion of the Rocky Mountains of northwestern Montana: Mont. Bur. Mines and Geology Mem. 4, 30 p. Map, scale 1 in. to about $7 \mathrm{mi}$.

* Clapp, C. H., Bevan, Arthur, and Lambert, G. S., 1921, Geology and oil and gas prospects of central and eastern Montana: Mont. Univ. Bull., Bur. Mines and Metallurgy, ser. 4, p. 1-69.

* Clark, F. R., 1920, The Farnham anticline, Carbon County, Utah: U. S. Geol. Survey Bull. 711, p. 1-13.

Cobban, W. A., 1945, Marine Jurassic formations of Sweetgrass Arch, Mont.: Am. Assoc. Petroleum Geologists Bull., v. 29, p. 1262-1303.

Cobban, W. A., Imlay, R. W., and Reeside, J. B., Jr., 1945, Type section of Ellis formation (Jurassic) of Montana: Am. Assoc. Petroleum Geologists Bull., v. 29, p. 451-453.

* Collier, A. J., 1920, Anticlines near Maverick Springs, Fremont County, Wyo. : U. S. Geol. Survey Bull. 711, p. 149-166.

* 1920, Oil in the Warm Springs and Hamilton domes, near Thermopolis, Wyo.: U. S. Geol. Survey Bull. 711, p. 61-73.

Comstock, T. B., 1874, Geological report, in Jones, W. A., Report upon the reconnaissance of northwestern Wyoming made in the summer of 1873 : 43d Cong., 1st sess., H. Ex. Doc. 285, p. 85-184; additional chaps. in later ed., p. 85-202, Waskington, 1875. Mnp, scale $1: 600,000$.

* Condit, D. D., 1916, Relations of the Embar and Chugwater formations in central Wyoming: U. S. Geol. Survey Prof. Paper 98, p. 263-270.; abs. Wash. Acad. Sci. Jour., v. 7, p. 162, 1917.

-_ 1917, Evidence in the Helena-Yellowstone Park region, Montana, of the great Jurassic erosion surface [abs.] : Geol. Soc. America Bull. 28, p. 161.

* 1918, Relations of late Paleozoic and early Mesozoic formations of southwestern Montana and adjacent parts of Wyoming: U. S. Geol. Survey Prof. Paper 120, p. 111-121.; abs., Wash. Acad. Sci. Jour., v. 9, p. 530-531, [1919].

- 1919, 0il shale in western Montana, southeastern Idaho, and adjacent parts of Wyoming and Utah: U. S. Geol. Survey Bull. 711, p. 15-40; abs., Wash. Acad. Sci. Jour., v. 9, p. 638. 
* Condit, D. D., 1924, Phosphate deposits in the Wind River Mountains, near Lander, Wyo.: U. S. Geol. Survey Bull. 764, 39 p. Map, scale 1: 125,000.

* - Finch, E. H., and Pardee, J. T., 1928, Phosphate rock in the Three Forks-Yellowstone Park region, Mont.: U. S. Geol. Survey Bull. 795, p. 147-209.

- Condra; G. E., and Reed, E. C., 1935, Permo-Pennsylvanian section of the Hartville area of Wyoming: Nebr. Geol. Survey, Geol. Paper 9, 46 p.

- 1940, Correlation of the Carboniferous and Permian horizons in the Black Hills and the Hartville uplift: Kans. Geol. Soc. Guidebook 14, p. 126-128.

* Condra, G. E., Reed, E. C., and Scherer, O. J., 1940, Correlations of the formations of the Laramie Range, Hartville uplift, Black Hills, and western Nebraska: Nebr. Geol. Survey Bull. 13, 52 p.

Cooley, J. L., 1946, Devonian of Bear River Range, Utah : Utah State Agri. Coll., Logan, Utah unpub. thesis.

Conper, C. L., and Sloss, L. L., 1943, Conodont fauna and distribution of a Lower Mississippian black shale in Montana and Alberta: Jour. Paleontology, v. 17, p. 167-176.

Cooper, G. A., and others, 1942, Correlation of Devonian sedimentary formations of North America : Geol. Soc. America Bull., v. 53, p. 1729-1794.

Cope, E. D., 1873, On a new genus of Pleurodira from the Eocene of Wyoming: Am. Philos. Soc. Proc. 12, p. 472-477.

Crawford, A. L., 1935, Archean(?) metaquartzites east of Bountiful, Utah [abs.] : Utah Acad. Sci., v. 12, p. 167.

Crickmay, C. H., 1931, Jurassic history of North America; its bearing on the development of continental structure: Am. Philos. Soc. Proc., v. 70, no. 1, p 15-102.

1. 1933, Attempt to zone the North American Jurassic on the basis of its brachiopods : Geol. Soc. America Bull., v. 44, p. 871-894; abs., v. 44, pt. 1, p 80.

- 1936, Study in the Jurassic of Wyoming: Geol. Soc. America Bull., v. 47, p. 541-564; abs., Proc. 1933, p. 74, 1934.

${ }^{*}$ Crockford, M. M. B., and Warren, P. S., 1935, The Cache Creek series of British Columbia : Royal Soc. Canada Proc. and Trans., 3d ser., v. 29, sec. 4, p. 160.

${ }^{*}$ Cross, Whitman, 1907, Stratigraphic results of a reconnaissance in western Colorado and eastern Utah : Jour. Geology, v. 15, p. 634-679.

${ }^{*}$ Curtis, H. A., 1938, Western phosphate deposits: Indus. Eng. Chemistry, v. 30, p. $973-979$.

Dake, C. L., 1918, The Hart Mountain overthrust and associated structures in Park County, Wyo. : Jour. Geology, v. 26, p. 44-45.

Daly, R. A., 1912, Geology of the North American Cordillera at the 49th parallel; Canada, Geol. Survey Mem. 38. Map, scale 1:62,500.

Dana, E. S., and Grinnell, G. B., 1876, Geological report in Ludlow, William, Report of reconnaissance * * to the Yellowstone National Park: p. 89-126, Washington. Also in U. S. Chief of Engineers Ann. Rept. 1876 : Cong. Doc., 44th Cong., 2 sess., H. Ex. Doc. 1, pt. 2, v. 2, pt. 3, App. N. N., p. 657-694.

Darton, N. H., 1904, Comparison of the stratigraphy of the Black Hills, Bighorn Mountains and Rocky Mountain Front Range: Geol. Soc. America Bull., v. 15, p. $379-448$.

*__ 1906, Fish remains in Ordovician rocks in the Bighorn Mountains, Wyoming, with a resume of Ordovician geology of the Northwest: Geol. Soc. America Bull., v. 17, p. 541-566. Map, scale 1 in. to about $20 \mathrm{mi}$.

*__ 1906, Geology of the Bighorn Mountains : U. S. Geol. Survey Prof. Paper: 51, p. $35-36$. Map, scale 1 in. to $4 \mathrm{mi}$. 
Darton, N. H., 1906, Geology of the Owl Creek Mountains : Cong. Doc., 59th Cong.; 1st sess., Sen. Doc. 219, p. 17-18, 31-32. Map, scale 1 in. to $4 \mathrm{mi}$.

* 1906, Description of the Bald Mountain and Dayton quadrangles, Wyo: ming: U. S. Geol. Survey Geol. Atlas, folio 141, map, structure section. Map, scale $1: 125,000$.

- 1906, Description of Cloud Peak and Fort McKinney quadrangles, Wyoming: U. S. Geol. Survey Geol. Atlas, folio 142, map, stratigraphic section. Map, scale $1: 125,000$.

*_- 1908, Paleozoic and Mesozoic of central Wyoming: Geol. Soc. America Bull., v. 19, p. 403-474. Map, scale 1 in. to $20 \mathrm{mi}$.

*Darton, N. H., Blackwelder, Eliot, and Siebenthal, C. E., 1910, Description of the Laramie and Sherman quadrangles, Wyoming: U. S. Geol. Survey Geol. Atlas, folio 173. Map, scale 1: 125,000.

*Darton, N. H., and Siebenthal, C. E., 1909, Geology and mineral resources of the Laramie Basin Wyo.: U. S. Geol. Survey Bull. 364, 99 p. Map, scale 1 in. to $1 \frac{1 / 2}{2} \mathrm{mi}$.

*DeFord, R. K., 1941, Permian problems [abs.] : Tulsa Geol. Soc. Digest, v. 9, p. 38-41.

*Deiss, C. F., 1933, Paleozoic formations of northwestern Montana: Mont. Bur. Mines and Geology Mem. 6, p. 21, pl. 6; abs., Northwest Science, v. 7, no. 2, p. 42.

1934, Cambrian-Algonkian unconformity in western Montana: Geol. Soc America Bull., v. 46, p. 95-124, 1935; abs., Proc. 1933, p. 382-383, 1934.

1936, Revision of type Cambrian formations and sections of Montana and Yellowstone National Park: Geol. Soc. America Bull., v. 47, p. 1257-1342; abs., Proc. 1935, p. 388.

1938, Cambrian formations and sections in part of Cordilleran trough: Geol. Soc. America Bull., v. 49, p. 1067-1168.

1938, Cambrian geography and sedimentation in Montana [abs.]: Geol. Soc. America Proc. 1937, p. 274.

1940, Cambrian geography and sedimentation in the central Cordilleran region: Geol. Soc. America Bull., v. 52, p. 1085-1115, 1941; abs., v. 51, no. 12, pt: 2 , p. 2021.

- 1943, Stratigraphy and structure of southwest Saypo quadrangle, Mont. : Geol. Soc. America Bull., v. 54, p. 205-262; abs., v. 52, no. 12, pt. 2, p. 1947. 1941.

* _ 1946, Stratigraphy and structure of phosphate rock northeast of Georgetown, Idaho [abs.] : Geol. Soc. America Bull., v. 57, p. 1265-1266.

* _ 1949, Phosphate deposits of the Deer Creek-Wells Canyon area, Caribou County, Idaho : U. S. Geol. Survey Bull. 955-C, 99 p.

Demok, F. K., Castor, H. R., and Bass, N. W., 1947, Map of Colorado showing dry holes and oil and gas fields: U. S. Geol. Survey Oil and Gas Inv. Prelim.. Map. 73.

Denson, M. D., Jr., and Morrisey, N. S., 1952, The Madison group [Mississippian] of the Big Horn and Wind River Basins, Wyo.: Wyo. Geol. Assoc. Guidebook 7, p. 37-43.

* DeSchmid, H. S., 1916, Investigation of a reported discovery of phosphate in Alberta : Canada Mines Br. Bull. 12, $38 \mathrm{p}$.

* _ 1917, A reconnaissance for phosphate in the Rocky Mountains; and for graphite near Cranbrook, B. C. : Canada Mines Br. Summary Rept. 1916, p. 22-35.

* Dobbin, C. E., Bowen, C. F., and Hoots, H. W., 1929, Geology and coal and' oil resources of the Hanna and Carbon Basins, Carbon County, Wyo.: U. S. Geol. Survey Bull. 804, p. 11-12. Map, scale 1: 62,500. 
* Dobbin, C. E., Hoots, H. W., and Dane, C. H., 1928, Geology and oil and gas possibilities of the Bell Springs district, Carbon County, Wyo.: U. S. Geol. Survey Bull. 796, p. 177-178.

*-Dobbin, C. E., and others, 1929, Geology of the Rock Creek oil field and adjacent areas, Carbon and Albany Counties, Wyo.: U. S. Geol. Survey Bull. 806, p. 136-137. Map, scale $1: 63,360$.

Dobrovolny, Ernest, 1941, Jurassic and Cretaceous strata of the Camp Davis area, Wyo.: Mich. Acad. Sci. Papers : v. 26, p. 431.

Donovan, J. H., 1950, Intertonguing of Green River and Wasatch formations in part of Sublette and Lincoln Counties, Wyo.: Wyo. Geol. Assoc. Guidebook 5, p. 59-65.

Dorf, Erling, 1934, Stratigraphy and paleontology of a new Devonian formation at Beartooth Butte, Wyo.: Jour. Geology, v. 42, p. 720-737. Map, no scale given.

- 1942, Upper Cretaceous floras of the Rocky Mountain region; Stratigraphy and paleontology of the Fox Hills and Lower Medicine Bow formations of southern Wyoming and northwestern Colorado: Carnegie Inst. Wash. Pub. 508, Contr. Paleontology, 168 p. Maps, various scales.

Dorf, Erling, and Lochman, Christine, 1940, Upper Cambrian formations in southern Montana : Geol. Soc. America Bull., v. 51, p. 541-556.

Dorr, J. A., Jr., 1952, Early Cenozoic stratigraphy and vertebrate paleontology of the Hoback Basin, Wyo.: Geol. Soc. America Bull. v. 63, no. 1, p. 59-94.

* Douglass, Earl, 1905, Some notes on the geology of southwestern Montana: Carnegie Mus. Annals, v. 3, p. 407-428.

* 1909, A geological reconnaissance in North Dakota, Montana, and Idaho; with notes on Mesozoic and Cenozoic geology: Carnegie Mus. Annals, v. 5, p. 211-288.

- 1914, Geology of the Uinta formation: Geol. Soc. America Bull., v. 25, p. 417-420.

Downs, G. R., 1947, Mesozoic stratigraphy of the Big Horn Basin area: Wyo. Geol. Assoc. Guidebook 2, p. 131-141.

* _ 1948, Regional relationships of Wind River Basin sediments : Wyo. Geol. Assoc. Guidebook 3, p. 140-147.

1952, Summary of Mesozoic stratigraphy, Big Horn Basin: Wyo. Geol. Assoc. Guidebook 7, p. 26-31.

* Dunbar, C. O., 1941, Permian faunas; a study in facies: Geol. Soc. America Bull., v. 52, p. 313-332.

Eardley, A. J., 1932, A limestone chiefly of algal origin in the Wasatch conglomerate, southern Wasatch Mountains, Utah: Mich. Acad. Sci. Papers, v. 16, p. $399-414$.

1933, Stratigraphy of the southern Wasatch Mountains, Utah: Mich. Acad. Sci. Papers, v. 18, p. 307-344.

1933, Structure and physiography of the southern Wasatch Mountains, Utah : Mich. Acad. Sci. Papers, v. 19, p. 377-400, 1934 ; abs., Geol. Soc. America Bull., v. 44, pt. 1, p. 83-84, 1933.

-_ 1944, Geology of the north-central Wasatch Mountains, Utah : Geol. Soc. America Bull., v. 55, p. 819-894 ; abs., Utah Acad. Sci. Proc., v. 19-20, 1941-43, p. 19. Maps, scales 1 in. to $2 \mathrm{mi}$., $1 \mathrm{in}$. to $1 \mathrm{mi}$.

1946, Paleozoic Cordilleran geosyncline and related orogeny: Jour. Geology, v. 55, p. 309-342, 1947 ; abs., Geol. Soc. America Bull., v. 57, p. 1189.

Eardley, A. J., and Hatch, R. A., 1940, Pre-Cambrian crystalline rocks of northcentral Utah: Jour. Geology, v. 48, p. 58-72.

1940, Proterozoic(?) rocks in Utah: Geol. Soc. America Bull., v. 51, p. 798-844. 
* Edmund, R. W., 1940, Structural geology and physiography of the northern end of the Teton Mountains, Wyo.: Iowa Univ. unpub. dissert., 163 p.; abs., Iowa Univ. Pub., Aims and Prog. Research Ser., no. 66. Map, scale 1 in. to $2 \mathrm{mi}$.

Eldridge, G. H., 1894, A geological reconnaissance in northwest Wyoming: U. S. Geol. Survey Bull. 119, 72 p. Map, scale 1 in. to $11 \frac{1}{2} \mathrm{mi}$.

Emmons, S. F., 1907, Uinta Mountains : Geol. Soc. America Bull., v. 18, p. 287-302.

Emmons, S. F., and Tower G. W., Jr., 1897, Economic geology of the Butte Special district: U. S. Geol. Survey Geol. Atlas, folio 38, p. 3-8. Map, scale $1: 15,000$.

Emmons, W. H., 1908, Geology of the Haystack stock, Cowles, Park County, Mont. : Jour. Geology, v. 16, p. 193-229. Map, scale 1 in. to about 21/4 mi.

* Emmons, W. H., and Calkins, F. C., 1913, Geology and ore deposits of the Philipsburg quadrangle, Mont. : U. S. Geol. Survey Prof. Paper 78, p. 70-74, 166. Map, scale $1: 125,000$.

Engle, A. E. J., 1947, Geology of the central Owl Creek Mountains, Wyo. [abs.] : Geol. Soc. America Bull., v. 58, no. 12, pt. 2, p. 1177-1178.

* Fanshawe, J. R., 2d, 1939, Structural geology of Wind River Canyon area, Wyoming: Am. Assoc. Petroleum Geologists Bull., v. 23, p. 1439-1492. Map, scale ap. 1 inch to about $11 / 2$ miles.

* Fath, A. E., and Moulton, G. F., 1924, Oil and gas fields of the Lost SoldierFerris district, Wyo.: U. S. Geol. Survey Bull. 756, 57 p. Maps, scales $1: 15,840,1: 125,000$.

Fenneman, N. M., and Gale, H. S., 1906, The Yampa coal field, Routt County, Colo.: U. S. Geol. Survey Bull. 285, p. 21.

Fenner, C. N., 1944, Rhyolite-basalt complex on Gardiner River, Yellowstone Park, Wyo. [a discussion] : Geol. Soc. America Bull., v. 55, p. 1081-1096.

Fenton, C. L., and Fenton, M. A., 1939, Pre-Cambrian and Paleozoic algae: Geol. Soc. America Bull., v. 50, p. 89-126.

* Field, R. M., and others, 1932, Yellowstone-Beartooth-Big Horn region: Internat. Geol. Cong., 16th sess., United States, 1933, Guidebook 24, Excursion C-2, 64 p. Maps, various scales.

* Fisher, C. A., 1906, Geology and water resources of the Bighorn Basin, Wyo.: U. S. Geol. Survey Prof. Paper 53, p. 17-18. Map, scale 1 in. to $4 \mathrm{mi}$.

Foerste, A. F., 1935, Big Horn and related cephalopods: Denison Univ. Bull., v. 35, no. 5, Jour. Sci. Lab., v. 30, p. 1-96.

* Forrester, J. D., 1937, Structure of the Uinta Mountains: Geol. Soc. America Bull., v. 48, p. 631-666. Map, scale 1 in. to $9 \frac{1 / 2}{\mathrm{mi}}$.

* Foster, H. L., 1947, Paleozoic and Mesozoic stratigraphy of northern Gros Ventre Mountains and Mount Leidy Highlands, Teton County, Wyo.: Am. Assoc. Petroleum Geologists Bull., v. 31, p. 1537-1593, 1947 ; abs., Geol. Soc. America Bull., v. 57, no. 12, pt. 2, p. 1194, 1946.

Frielinghausen, K. W., 1952, The Phosphoria formation of southern and southeastern Big Horn Basin, Big Horn, Hot Springs, and Washakie Counties, Wyo. : Wyo. Geol. Assoc. Guidebook 7, p. 55-57.

Gale, H. S., 1909, Coal fields of northwestern Colorado and northeastern Utah : U. S. Geol. Survey Bull. 341, p. 283-315. Maps, scale 1 in. to $4 \mathrm{mi}$.

*_ 1910, Geology of the copper deposits near Montpelier, Bear Lake County, Idaho: U. S. Geol. Survey Bull. 430, p. 114-115.

* 1911, Rock phosphate near Melrose, Mont. : U. S. Geol. Survey Bull. 470, p. 440-451. Map, scale 1 in. to $7 \mathrm{mi}$.

* Gale, H. S., and Richards, R. W., 1910, Preliminary report on the phosphate deposits in southeastern Idaho and adjacent parts of Wyoming and.Utah: U. S. Geol. Survey Bull. 430, p. 457-535. Maps, scale 1:62,500. 
* Gardner, L. S., 1944, Phosphate deposits of the Teton Basin area, Idaho and Wyoming: U. S. Geol. Survey Bull. 944, p. 1-36. Map, scale 1: 48,000.

Gardner, L. S., Hendricks, T. A., Hadley, H. D., and Rogers, C. P., Jr., 1945, Mesozoic and Paleozoic rocks in the mountains of south-central Montana [Columnar sections] : U. S. Geol. Survey Oil and Gas Inv. Prelim. Chart 18.

*_ 1946, Stratigraphic sections of Upper Paleozoic and Mesozoic rocks in south-central Montana: Mont. Bur. Mines and Geology Mem. 24, 100 p.

George, R. D., 1927, Geology and natural resources of Colorado: 228 p., Boulder, Colo. : Colo. Univ. Press.

* Gilluly, James, 1929, Geology and oil and gas prospects of part of the San Rafael Swell, Utah : U. S. Geol. Survey Bull. 806, p. 82.

1932, Geology and ore deposits of the Stockton and Fairfield quadrangles, Utah : U. S. Geol. Survey Prof. Paper 173, 171 p.

* Gilluly, James, and Reeside, J. B., Jr., 1928, Sedimentary rocks of the San Rafael Swell and some adjacent areas in eastern Utah: U. S. Geol. Survey Prof. Paper 150, p. 64 .

Girty, G. H., 1903, The Carboniferous formations and faunas of Colorado: U. S. Geol. Survey Prof. Paper 16, 546 p.

1908, The Guadalupian fauna: U. S. Geol. Survey Prof. Paper 58, p. 5-55.

*__ 1910, The fauna of the phosphate beds of the Park City formation in Idaho, Wyoming, and Utah: U. S. Geol. Survey Bull, 436, 82 p.

Goddard, Malcolm, 1907, Fish remains from the marine lower Triassic of Aspen Ridge, Idaho : Calif. Univ., Dept. Geol. Bull., v. 5, p. 145-148.

Granger, Walter, 1910, Tertiary faunal horizons in the Wind River Basin, Wyo., with descriptions of new Eocene mammals : Am. Mus. Nat. History Bull., v. 28, p. 235-251.

Green, Jack, and Young, W. A., Jr., 1937, The Park City mining district [Utah] : Compass, v. 17, p. 159-162.

Griswold, L. S., 1898, The geology of Helena, Mont., and vicinity : Jour. Assoc. Eug. Soc., v. 20, p. 51-68.

Gunnell, F. H., 1931, Brazer formation of northern Utah and its telotremate brachiopods, Am. Midland Naturalist, v. 13, no. 5, p. 282-301, 1932 ; abs., Geol. Soc. America Bull., v. 42, p. 330.

Gwynne, C. S., 1938, Granite in the Wind River Canyon: Geol. Soc. America Bull., v. 49, p. 1417-1424; abs., Proc. 1936, p. 77, 1937.

* Hadley, H. D., Gardner, L. S., and Rogers, C. P., Jr., 1945, Graphic sections of Mesozoic and Paleozoic rocks that underlie basin areas in south-central Montana: U. S. Geol. Survey Oil and Gas Inv. Prelim. Chart 19.

Hague, Arnold, 1899, Description of the Absaroka quadrangle: U. S. Geol. Survey Geol. Atlas, folio 52. Maps, scale $1: 125,000$.

* Hague, Arnold, Iddings, J. P., and Weed, W. H., 1899, Geology of the Yellowstone National Park: U. S. Geol. Survey Mon. 32, pt. 2, Descriptive geology, petrography, 'and paleontology, 839 p. Maps, various scales.

Hague, Arnold, Weed, W. H., and Iddings, J. P., 1896, Yellowstone National Park sheets, general description: U. S. Geol. Survey Geol. Atlas, folio 30. Map, scale $1: 125,000$.

Hale, L. A., 1950, Stratigraphy of the Upper Cretaceous Montana Group in the Rock. Springs uplift, Sweetwater County, Wyo.: Wyo. Geol. Assoc. Guidebook 5, p. 49-58.

Hammar, A. A., and Lloyd, A. M., 1926, Notes on the Quadrant formation of eastcentral Montana: Am. Assoc. Petroleum Geologists Bull., v. 10, p. 986-996.

"Hancock, E. T., 1925, Geology and coal resources of the Axial and Monument Butte quadrangles, Moffat County, Colo.: U. S. Geol. Survey Bull. 757, p. 8-10. Map, scale 1: 62,500. 
Hansen, G. H., 1934, An interpretation of past climatic cycles from observations made of Utah lake sediments: Utah Acad. Sci. Proc., v. 11, p. 161-167.

*Hanson, A. M., 1942, Phosphate deposits in western Summit, Wasatch, Salt Lake, Morgan, and Weber Counties, Utah: Utah State Agr. Coll., Logan, Utah, unpub. thesis.

*Hares, C. J., 1916, Anticlines in central Wyoming: U. S. Geol. Survey Bull. 641-I, p. 243.

Hares, C. J., and others, 1946, Geologic map of the Southern part of the Wind River basin and adjacent areas in central Wyoming: U. S. Geol. Survey Oil and Gas Inv. Prelim. Map 60. Scale about 1 in. to $2 \mathrm{mi}$.

Hayden, F. V., 1870, Sections of strata belonging to the "Bear River Group" near Bear River City, Wyoming Territory: Am. Philos. Soc. Proc. 11, p. $420-425$.

1876, Notes descriptive of some geologic sections of the country about the headwaters of the Missouri and Yellowstone Rivers: U. S. Geol. and Geog. Surv. Terr., v. 2, Bull. 3, p. 197-209.

Haynes, W. P., 1916, The fauna of the upper Devonian in Montana-Pt. 2, The stratigraphy and the Brachiopoda: Carnegie Mus. Ann., v. 10, p. 13-54.

*Heald, K. C., 1921, The oil-bearing horizons of Wyoming: Am. Assoc. Petroleum Geologist Bull., v. 5, p. 191-192.

*Heaton, R. L., 1929, Relation of accumulation to structure in northwestern Colorado, in Structure of typical American oil fields, v. 2, p. 93-114: Am. Assoc. Petroleum Geologists.

*_ 1933, Ancestral Rockies and Mesozoic and late Paleozoic stratigraphy of Rocky Mountain region: Am. Assoc. Petroleum Geologists Bull., v. 17, p. 109-124.

*__ 1937, Stratigraphy versus structure in Rocky Mountain region: Am. Assoc. Petroleum Geologists Bull., v. 21, p. 1251-1258.

*__ 1950, Late Paleozoic and Mesozoic history of Colorado and adjacent areas : Am. Assoc. Petroleum Geologists Bull., v. 34. Maps, no scale given.

Henderson, Junius, 1910, Scientific expedition to northwestern Colorado in 1909 ; itinerary, topography and geology : Colo. Univ. Studies, v. 7, p. 101-112.

*Hendrickson, V. J., 1943, Elk Basin oil and gas field, Carbon County, Mont. and Park County, Wyo.: Mines Mag., v. 33, p. 500-507, 578, 580.

Hewett, D. F., 1914, The Shoshone River section, Wyoming: U. S. Geol. Survey Bull. 541, p. 89-113.

*ـ 1920, The Heart Mountain overthrust, Wyoming: Jour. Geology, v. 28, p. 536-557. Geologic sketch map.

*__ 1926, Geology and oil and coal resources of Oregon Basin, Meeteetse, and Grass Creek Basin quadrangles, Wyo.: U. S. Geol. Survey Prof. Paper 145, p. 11. Maps, scale $1: 62,500$.

*Hewett, D. F., and Lupton, C. T., 1917, Anticlines in the southern part of the Big Horn Basin, Wyo.: U. S. Geol. Survey Bull. 656, p. 17-18; abs. Wash. Acad. Sci. Jour., v. 8, p. 204-205, 1918. Map, scale 1:500,000.

*Hintze, F. F., 1913, A contribution to the geology of the Wasatch Mountains, Utah: N. Y. Acad. Sci. Annals, v. 23, p. 85-142.

1934, The Proterozoic-Paleozoic contact in the western Uinta and central Wasatch Mountains, Utah: Utah Acad. Sci. Proc., v. 11, p. 165-166.

Honkala, F. S., Replogle, B. K., and Gosman, R. F., 1951, Stratigraphy of the Phosphoria formation, Centennial Range, southwestern Montana [abs.]: Geol. Soc. America Bull., v. 62, no. 12, pt. 2, p. 1537.

- Horberg, C. L., Nelson, V. E., and Church, H. V., 1949, Structural trends in central western Wyoming: Geol. Soc. America Bull., v. 60, p. 183-216. Map, scale 1 in. to about $12 \mathrm{mi}$. 
Horberg, Leland, and Fryxell, F. M., 1942, Pre-Cambrian metasediments in Grand Teton National Park, Wyo.: Am. Jour. Sci., v. 240, no. 6, p. 385-393.

- Howard, L. O., 1916, Geology of the Cottonwood districts: Min. Sci. Press., v. 112, p. 557-562. Map, no scale given.

Howell, B. F., and others, 1944, Correlation of the Cambrian formations of North America [Chart 1] : Geol. Soc. America Bull., v. 55, p. 993-1003.

* Huddle, J. W., and McCann, F. T., 1947, Geologic map of Duchesne River area, Wasatch and Duchesne Counties, Utah: U. S. Geol. Survey Oil and Gas Inv. Prelim. Map 75. Scale 1 in. to $1 \mathrm{mi}$.

- 1947, Late Paleozoic rocks exposed in the Duchesne River area, Duchesne County, Utah: U. S. Geol. Survey Circ. 16, 21 p.

Hughes, R. V., 1933, The geology of the Beartooth Mountain front in Park County, Wyo.: Natl. Acad. Sci. Proc., v. 19, no. 2, p. 239-263. Map, scale 1 in. to $4 \mathrm{mi}$.

Hunter, L .D., 1952, Frontier formation along the eastern margin of the Big Horn Basin, Wyo. in Wyo. Geol. Assoc. Guidebook 7, p. 63-66.

Hyatt, Alpheus, and Smith, J. P., 1905, The Triassic cephalopod genera of America : U. S. Geol. Survey Prof. Paper 40, 394 p.

- Iddings, J. P., 1896, Description of the Yellowstone National Park, Wyo.: U. S. Geol. Survey Geol. Atlas, folio 30. Maps, scale 1: 125,000.

Iddings, J. P., and Weed, W. H., 1894, Description of the Livingston quadrangle, Mont.: U. S. Geol. Survey Geol. Atlas, folio 1. Maps, scale 1:250,000.

Imlay, R. W., 1950, Jurassic rocks in the mountains along the west side of the Green River Basin: Wyo. Geol. Assoc. Guidebook 5, p. 37-48.

Imlay, R. W., Gardner, L. S., and Rogers, C. P., Jr., 1948, Marine Jurassic formations of Montana: U. S. Geol. Survey Oil and Gas Inv. Prelim. Chart 32.

- Jamison, C. E., 1911, Geology and mineral resources of a portion of Fremont County, Wyo.: Wyo. State Geologist's Office, Bull. 2, ser. B., 90 p. Map, scale $1 \mathrm{in}$. to $2 \mathrm{mi}$.

Jepson, G. L., 1930, Stratigraphy and paleontology of the Paleocene of northeastern Park County, Wyo.: Am. Philos. Soc. Proc., v. 69, no. 7, p.. 463-528.

- Johnson, G. D., 1934, Geology of the mountain uplift transected by the Shoshone Canyon, Wyo.: Jour Geology, v. 42, p. 815 and 819 . Map, scale $1: 125,000$.

- Johnson, J. H., 1945, A résumé of the Paleozoic stratigraphy of Colorado: Colo. School Mines Quart., v. 40, no. 3, p. 97-98.

- Jones, C. T., 1939, Geology of Wind River Canyon, Wyo.: Am. Assoc. Petroleum Geologists Bull., v. 23, p. 476-491.

-_ 1940, Subsurface section from Big Muddy fleld, Converse County, Wyo, through Nebraska to central Kansas uplift, Ellis County, Kans.: Kans. Geol. Soc. Guidebook 14, p. 140-141, 1 flg.

- Karlstrom, T. N. V., 1948, Geology and ore deposits of the Hecla mining district, Beaverhead County, Mont.: Mont. Bur. Mines and Geology Mem. 25, $87 \mathrm{p}$. Maps, scale 1 in. to $1000 \mathrm{ft}$., and 1 in. to $1 / 2 \mathrm{mi}$.

- Kay, J. L., 1934, The Tertiary formations of the Uinta Basin, Utah : Carnegle Mus. Annals, v. 23, p. 357-372. Map, scale 1 in. to $8 \mathrm{mi}$.

* Keller, W. D., 1941, Petrography and origin of the Rex chert. : Geol. Soc. America Bull., v. 52, p. 1279-1298; abs., v. 50, p. 1915-1916, 1939.

Ketterer, W. P., and Swirczynski, R. P., 1952, Preliminary lithofacies study of the Phosphoria formation, Big Horn Basin, Wyo.: Wyo. Geol. Assoc. Guidebook 7, p. 53-54. 
Keyes, C. R., 1922, Climatic index of Bonneville Lake beds : Pan-Am. Geologist, v. 38, p. $422-424$.

1926, Ancient rock column of Montana : Pan-Am. Geologist, v. 46, p. 195-232.

Kindle, E. M., 1908, The fauna and stratigraphy of the Jefferson limestone in the northern Rocky Mountain region: Bull. Am. Paleontology, v. 4, no. 20, p. 7-39.

King, Clarence, 1876, Paleozoic subdivisions on the 40th parallel : Am. Jour. Sci., 3d ser., v. 11, p. 475-482.

* King, P. B., 1934, Permian stratigraphy of Trans-Pecos Texas: Geol. Soc. America Bull., v. 45, p. 735 and 786.

*_ 1937, Geology of the Marathon region, Texas: U. S. Geol. Survey Prof. Paper 187, p. 103-104.

*King, P. B., and King, R. E., 1929, Stratigraphy of outcropping Carboniferous and Permian rocks of Trans-Pecos, Texas: Am. Assoc. Petroleum Geologists Bull., v. 13, p. 913-920.

* King, R. E., 1931, The geology of the Glass Mountains, Tex., Pt. II, Faunal summary and correlation of the Permian formations, with description of Brachiopoda : Tex. Univ. Bull. 3042, p. 10-35.

* King, R. H., 1947, Phosphate deposits near Lander, Wyo.: Wyo. Geol. Survey Bull. 39, 84 p. Maps, scales 1 in. to $500 \mathrm{ft}$., 1 in. to $2 \mathrm{mi}$.

Kinney, D. M., 1951, Geology of the Uinta River and Brush Creek-Diamond Mountain areas, Duchesne and Uintah Counties, Utah: U. S. Geol. Survey Oil and Gas Inv. Map OM 123. Scale $1: 63,360$.

-Kinney, D. M., and Rominger, J. F., 1947, Geology of the Whiterocks River-Ashley Creek area, Uintah County, Utah: U. S. Geol. Survey Oil and Gas Inv. Prelim. Map 82. Scale 1 in. to $1 \mathrm{mi}$.

* Kirkham, V. R. D., 1922, Petroleum possibilities of certain anticlines in southeastern Idaho: Idaho Bur. Mines and Geology Bull. 4, 36 p. Maps, scale 1 in. to $1 \mathrm{mi}$.

*__ 1923, Notes on the geology of eastern Bear Lake County, Idaho, with reference to oil possibilities: Idaho Bur. Mines and Geology Pamph. 7, 6 p.

-_ 1924, Geology and oil possibilities of Bingham, Bonneville, and Caribou Counties, Idaho: Idaho Bur. Mines and Geology Bull. 8, 116 p. Maps, scale 1 in to about $1 \% \mathrm{mi}$.

- 1925, Geologic conditions, oil possibilities, and drilling progress in Teton County, Idaho: Idaho Bur. Mines and Geology Press Bull. 15, December. Map, scale 1 in. to $11 / 2 \mathrm{mi}$.

*__ 1927, A geological reconnaissance of Clark and Jefferson and parts of Butte, Custer, Fremont, Lemhi, and Madison Counties, Idaho: Idaho Bur. Mines and Geology Pamph. 19, p. 20-21, 42. Map, scale 1 in. to about 63/4 mi.

* Knappen, R. S., and Moulton, G. F., 1930, Geology and mineral resources of parts of Carbon, Big Horn, Yellowstone, and stillwater Counties, Mont. : U. S. Geol. Survey Bull. 822, p. 14, pl. 2. Map, scale 1: 125,000.

* Knight, S. H., 1916, Lithogenesis and stratigraphy of the red beds of southeastern Wyoming [abs.] : Geol. Soc. America I3ull., v. 27, p. 120-122.

- __ 1917, Age and origin of the red beds of southeastern Wyoming [abs.] : Geol. Soc. America Bull., v. 28, p. 168.

* 1 1929, The Fountain and the Casper formations of the Laramie Basin; a study on genesis of sediments : Wyo. Univ. Pub. in Sci., Geol., v. 1, 82 p. Knight, W. C., and Slosson, E. E., 1897, The petroleum of the Shoshone anticlinal : Wyo. Univ. School Mines, Petroleum ser. Bull. 2, 34 p. 
Knight, W. C. 1902, The Laramie Plains red beds and their age: Jour. Geology, v. 10 p. $413-422$.

1903, Coal fields of southern Uinta County, Wyo. [abs.]: Geol. Soc. America Bull., v. 13 p. 542-544.

* Knopf, Adolph, 1913, Ore deposits of the Helena mining region, Montana : U. S. Geol. Survey Bull. 527, p. 22 . Map, scale $1: 250,000$.

* Krampert, E. W., 1949, Commercial oil in Cambrian beds, Lost Soldier field, Carbon and Sweetwater Counties, Wyo.: Am. Assoc. Petroleum Geologists Bull., v. 33, p. 1998-2010.

Kummel, Bernhard, Jr., 1943, The Thaynes formation, Bear Lake Valley, Idaho: Am. Jour. Sci., v. 241, p. 316-332.

- 1950, Triassic stratigraphy of the area around the Green River Basin, Wyo. : Wyo. Geol. Assoc. Guidebook 5, p. 28-36.

* La Fleiche, Pierre, 1944, Geologic aspect of Wyoming and outlook for development [of oil and gas fields] : Oil and Gas Jour., v. 43, no. 13 p. 38, 41-42.

*___ 1945, Wyoming; Pt. 1, General geologic features : Oil Weekly, v. 118, no. 5, p. 30-33; Pt. 2, Oil and gas prospects, no. 8, p. 46-50. Maps, small scale.

Lammers, E. C. H., 1937, Structural geology of the Livingston Peak area, Mont.: Jour. Geology, v. 45, p. 268-295. Maps, scale 1 in. to about $11 / 8 \mathrm{mi}$.

Langenheim, R. L. Jr., 1952, Pennsylvanian and Permian stratigraphy in Crested Butte quadrangle, Gunnison County, Colo.: Am. Assoc. Petroleum Geologists Bull. v. 36, no. 4, p. 543-574.

Lee, W. T., 1924, Geography, geology, and physiography of the Great Salt Lake basin: U. S. Geol. Survey Water Supply Paper 517, p. 3-9.

*_ 1927, Correlation of geologic formations between east-central Colorado, central Wyoming, and southern Montana: U. S. Geol. Survey Prof. Paper $149,80 \mathrm{p}$.

* Lee, W. T., Stone R. W., Gayle, H. S., and others, 1915, Guidebook of the western United States; Pt. B, The overland route, with a side trip to Yellowstone Park : U. S. Geol. Survey Bull. 612, 244 p.

Lewis, G. E., 1947, Tertiary geology of northeastern Wind River Basin [abs.] : Wash. Acad. Sci. Jour., v. 37, no. 10, p. 371.

* Loughlin, G. F., 1913, Reconnaissance in the southern Wasatch Mountains, Utah: Jour. Geology, v. 21, p. 436-452; abs., Wash. Acad. Sci. Jour., v. 3, p. $50-51$.

* Love, J. D., 1934, The geology of the western end of the Owl Creek Mountains, Wyo. Geol. Survey Bull. 24, 25 p. Map, scale 1 in. to about $2 / 3 \mathrm{mi}$.

1937, Cenozoic formations in the northwestern part of the Wind River Basin, Wyo. [abs.] : Geol. Soc. America Proc. 1936, p. 88.

*__ 1939, Geology along the southern margin of the Absaroka Range, Wyo.: Geol. Soc. America Special Paper 20, p. 11-12, 31-38, pls. 8 and 17. Map, scale 1 in. to about $1 \frac{1}{4} \mathrm{mi}$.

1940, Thrust faulting at the southern end of the Big Horn Mountains, Wyo. [abs.] : Geol. Soc. America Bull., v. 51, p. 1934.

1941, Geology along the southern margin of the Absaroka Range-a reply: Jour. Geology, v. 49, p. 101-106.

- 1945, Stratigraphic sections and thickness maps of lower Cretaceous and nonmarine Jurassic rocks of central Wyoming: U. S. Geol. Survey Oil and Gas Inv. Prelim. Chart 13.

*_ 1948, Mesozoic stratigraphy of the Wind River Basin, central Wyoming: Wyo. Geol. Soc. Guidebook 3, p. 96-111.

- 1950, Paleozoic rocks on the southwest flank of the Wind River Mountains, near Pinedale, Wyo. : Wyo. Geol. Assoc. Guidebook 5, p. 25-27. 
Love, J. D., Johnson, C. O., and Nace, H. L. 1945, Stratigraphic sections and thickness maps of Triassic rocks in central Wyoming: U. S. Geol. Survey Oil and Gas Inv. Prelim. Chart 17.

Love, J. D., Tourtelot, H. A., and Johnson, C. O. 1945, Stratigraphic sections and thickness maps of Jurassic rocks in central Wyoming: U. S. Geol. Survey Oil and Gas Inv. Prelim. Chart 14.

*_ 1947, Stratigraphic sections of Mesozoic rocks in central Wyoming: Wyo. Geol. Survey Bull. 38, 59 p.

Love, J. D., and Weitz, J. L., 1951, Geologic map of the Powder River Basin, and adjacent areas, Wyo.: U. S. Geol. Survey Oil and.Gas Inv. Map OM 122. Scale 1 in. to $5 \mathrm{mi}$.

* Lovering, T. S., 1929, The New World or Cook City mining district, Park County, Mont. : U. S. Geol. Survey Bull. 811, pl. 6. Map, scale 1 : 31,680.

Ludlum, J. S., 1942, Pre-Cambrian formations at Pocatello, Idaho : Jour. Geology, v. 50, p. 85-95. Map, scale 1 in. to $2 \frac{1}{2} \mathrm{mi}$.

1943, Structure and stratigraphy of part of the Bannock Range, Idaho: Geol. Soc. America Bull., v. 54, p. 978-986. Map, scale 1 in. to $3 \mathrm{mi}$.

Lull, R. S., 1942, Chugwater footprints from Wyoming: Am. Jour. Sci., v. 240, no. 7 , p. 500-504.

Lupton, C. T., 1912, The Deep Creek district of the Vernal coal field, Uinta[h] County, Utah: U. S. Geol. Survey Bull. 471, p. 579-594.

1916, Notes on the stratigraphic and structural relations in southern and eastern Big Horn Basin, Wyo. [abs.] Wash. Acad. Sci. Jour., v. 6, p. 310-311. 1916, Oil and gas near Basin, Big Horn County, Wyo.: U. S. Geol. Survey Bull. 621, p. 157-190. Maps, scales $1: 125,000,1: 62,500$.

- Lupton, C. T., and Condit, D. D., 1916, Gypsum in the southern part of the Bighorn Mountains, Wyo.: U. S. Geol. Survey Bull. 640, p. 139-157; abs., Wash. Acad. Sci. Journ., v. 7, p. 78, 1917.

- Lupton, C. T., and Lee, W. T., 1921, Geology of the Cat Creek oil field, Fergus and Garfield Counties, Mont.: Am. Assoc. Petroleum Geologists Bull. 5, p. 259.

- McCabe, W. S., 1947, The Elk Basin field, Park County, Wyo., and Carbon County, Mont. [abs.] : Am. Assoc. Petroleum Geologists - Soc. Econ. Paleontologists and Mineralogists-Soc. Econ. Geophysicists Joint Ann. Mtg., Los Angeles, Mar. 24-30, Program, p. 29.

- 1948, Elk Basin anticline, Park County, Wyo., and Carbon County, Mont. : Am. Assoc. Petroleum Geologists Bull., v. 32, p. 59, 67. Aerial photograph, geology plotted.

McKee, E. D., 1942, Marginal Paleozoic seas of northern Arizona [abs.] : Pan-Am. Geologist, v. 77, p. 235-236.

* McKelvey, V. E., 1946, Preliminary report on stratigraphy of phosphatic shale member of the Phosphoria formation in western Wyoming, southeastern Idaho, and northern Utah: U. S. Geol. Survey open-file report, $162 \mathrm{p}$.

- 1949, Geological studies of the western phosphate field : Am. Inst. Min. Metall. Engineers Trans., v. 184, p. 270-280; Min. Eng., v. 1, p. 270-279.

- McKelvey, V. E. and others, 1951, Stratigraphic sections of the Phosphoria formation in Idaho : U. S. Geol. Survey open-file rept.

- 1951, Stratigraphic sections of the Phosphoria formations in Idaho, Montana, Utah, and Wyoming : U. S. Geol. Survey open-file rept.

- Mansfield, G. R., 1915, Geology of the Fort Hall Indian Reservation, Idaho, [abs.] : Wash. Acad. Sci. Jour., v. 5, p. 492-493.

- 1916, A reconnaisance for phosphate in the Salt River Range, Wyo.: U. S. Geol. Survey Bull. 620, p. 331-349. Map, scale 1 : 62,500. 
*Mansfield, G. R., 1916, Subdivisions of the Thaynes limestone and Nugget sandstone, Mesozoic, in the Fort Hall Indian Reservation, Idaho : Wash. Acad. Sci. Jour., v. 6, p. 31-42.

*_1916, Types of Rocky Mountain structure in southeastern Idaho: Jour. Geology, v. 29, p. 444-468, 1921 ; abs., Wash. Acad. Sci. Jour., v. 6, p. 565.

*—_ 1920, Geography, geology, and mineral resources of the Fort Hall Indian Reservation, Idaho, with a chapter on water resources by W. B. Heroy : U. S. Geol. Survey Bull. 713, 152 p. Map, scale 1:125,000.

1920, The Wasatch and Salt Lake formations of southeastern Idaho: Am. Jour. Sci., 4th ser., v. 49, p. 339-406.

1920, Triassic and Jurassic formations in southeastern Idaho and neighboring regions : Am. Jour. Sci., 4th ser., v. 50, p. 53-64.

*_ 1920, Coal in eastern Idaho: U. S. Geol. Survey Bull. 716, p. 123-153. abs., Wash. Acad. Sci. Jour., v. 11, no. 9, p. 193, 1921. Map, scale 1 in. to 2 mi. 1921, Igneous geology of southeastern Idaho: Geol. Soc. America Bull., v. 32, p. 249-266. Map, scale 1 in. to $4 \mathrm{mi}$.

*__ 1927, Geography, geology, and mineral resources of part of southeastern Idaho: U. S. Geol. Survey Prof. Paper 152, 409 p. Maps, various scales. 1927, Summary of the geology of southeastern Idaho with notes on recent work [abs.] : Wash. Acad. Sci. Jour., v. 17, p. 129-130.

*__ 1928, Geography, geology, and mineral resources of part of southeastern Idaho, a summary [abs.] : Geol. Soc. America Bull., v. 39, p. 191 ; Pan-Am. Geologist, v. 49, no. 2, p. 144 ; no. 4, p. 299-300.

*_ 1929, Geography, geology, and mineral resources of the Portneuf quadrangle, Idaho: U. S. Geol. Survey Bull. 803,110 p. Map, scale 1 in. to $1 \mathrm{mi}$.

-_ 1931, Some problems of the Rocky Mountain phosphate fleld: Econ. Geology, v. 26, p. 353-374.

*__ 1937, Role of physical chemistry in stratigraphic problems : Econ. Geology, v. 32, p. 533-549.

Mansfield, G. R., and Larsen, E. S., 1915, Nepheline basalt in the Fort Hall Indian Reservation, Idaho: Wash. Acad. Sci. Jour., v. 5, p. 463-468.

Mansfield, G. R., and Ross, C. S., 1935, Welded rhyolite tuffs in southeastern Idaho: Am. Geophys. Union Trans. 16th Ann. Mtg., pt. 1, p. 308-321, Natl. Research Council.

Mansfleld, G. R., and Roundy, P. V., 1916, Some Jurassic and Cretaceous formations of southeastern Idaho [abs.] : Wash. Acad. Sci. Jour., v. 6, p. 157.

1916, Revision of the Beckwith and Bear River formations of southeastern Idaho: U. S. Geol. Survey Prof. Paper 98, p. 75-84, 1917; abs., Wash. Acad. Sci. Jour., v. 6, p. 565 .

1916, Stratigraphy of some formations hitherto called Beckwith and Bear River in southeastern Idaho [abs.] : Geol. Soc. America Bull. 27, p. 70-71.

*Maravich, M. D., 1941, Geology of Freezeout Mountain-Bald Mountain area, Carbon County, Wyo.: Am. Assoc. Petroleum Geologists Bull., v. 25, p. 883-897.

*Marzel, J. G., 1930, Fifteenth biennial report of the State geologist of the State of Wyoming, for the period October 1, 1928-September 30, 1930, 214 p.

Masters, J. A., 1952, The Frontier formation of Wyoming: Wyo. Geol. Assoc. Guidebook 7, p. 58-62.

*Mathews, A. A. L., 1931, Pre-Mesozoic stratigraphy of the central Wasatch Mountains [abs.] : Ohio Jour. Sci., v. 31, p. 279-280.

- 1931, Mesozoic stratigraphy of the central Wasatch Mountains: Oberlin Coll. Lab. Bull., new ser., no. 1, 50 p.

Maxey, G. B., 1946, Cambrian stratigraphy in the northern Wasatch region : Utah State Agri. Coll., Logan, unpub. thesis. 
Miller, A. K., 1930, Age and correlation of the Bighorn formation of northwestern United States : Am. Jour. Sci., 5th ser., v. 20, p. 195-213.

Miller, A. K., and Carrier, J. B., 1942, Ordovician cephalopods from the Bighorn Mountains of Wyoming: Jour. Paleontology, v. 16, p. 531-548.

*Miller, A. K., and Cline, L. M., 1934, Cephalopods of the Phosphoria formation of northwestern United States: Jour. Paleontology, v. 8, p. 281-302, 1 pl.

*Miller, A. K., and Crockford, M. B., 1936, Permian cephalopods from British Columbia : Royal Soc. Canada Trans., 3d ser., sec. 4, v. 30, p. 23-28.

*Miller, A. K., and Thomas, H. D., 1936, The Casper formation [Pennsylvanian] of Wyoming and its cephalopod fauna: Jour. Paleontology, v. 10, p. 715-738.

*Miller, A. K., and Warren, P. S., 1933, A Propinacoceras from North America: Am. Jour. Sci., 5th ser., v. 26, p. 295-299.

Miller, B. M., 1935, Cambrian stratigraphy of northwestern Wyoming: Jour. Geology, v. 44, no. 2, pt. 1, p. 113-144, 1936; abs., Geol. Soc. America Proc. 1934.

1936, Cambrian trilobites from northwestern Wyoming : Jour. Paleontology, v. 10, p. 23-34.

Miller, G. W., 1904, Geology of the Butte Mining district, Mont. : Ores and Metals, จ. 13, no. 10, p. 15-16; no. 11, p. 19-20.

Moore, R. C., and others, 1944, Correlation of Pennsylvanian formations of North America : Geol. Soc. America Bull., v. 55, p. 657-706.

* Morgan, G. B., 1921, Areal geology of Wyoming; correlation table and production data [on reverse of geological map of Wyoming] : 3d ed., Cheyenne, Wyo., G. B. Morgan and C. S. Hill. Scale 1 in. to $18 \mathrm{mi}$.

* Moritz, C. A., 1951, Triassic and Jurassic stratigraphy of southwestern Montana : Am. Assoc. Petroleum Geologists Bull., v. 35, no. 8, p. 1781-1814.

* Neely, Joseph, 1934, The geology of the north end of the Medicine Bow Mountains, Carbon County, Wyo.: Wyo. Geol. Survey Bull. 25, 35 p. Map, scale 1 in. to $11 / 2 \mathrm{mi}$.

1937, Stratigraphy of Sundance formation and related Jurassic rocks in Wyoming and their petroleum aspects: Am. Assoc. Petroleum Geologists Bull., v. 21, p. 715-770.

Newberry, J. S., 1881, Geological facts recently observed in Montana, Idaho, Utah and Colorado: New York Acad. Sci. Trans. 1, p. 4-8, 1881; abs., Science v. 2, p. 523-524.

* Newell, N. D., 1948, Key Permian section, Confusion Range, western Utah : Geol. Soc. America Bull., v. 59, p. 1053-1058.

Newell, N. D., and Kummel, B. J., 1940, Permo-Triassic boundary in southeastern Idaho and western Wyoming [abs.] : Oil and Gas Jour., v. 38, no. 48, p. 66.

*—1941, Permo-Triassic boundary in Idaho, Montana and Wyoming: Am. Jour. Sci., v. 239, p. 204-208.

* 1941, Permian-Triassic relations in the middle Rockies [abs.]: Oil and Gas Jour., จ. 39, no. 47, p. 66.

- 1942, Lower Eo-Triassic stratigraphy, western Wyoming and southeast Idaho : Geol. Soc. America Bull., v. 53, p. 937-996.

Nightingale, W. T., 1942, Petroleum and natural gas in the non-marine Wasatch formation of northwest Colorado and southwest wyoming [abs.]: Am. Ass0c. Petroleum Geologists Bull, , . 26, p. 900.

Nolan, T. B., 1928, A late Paleozoic positive area in Nevada: Am. Jour. Sci., 5th ser., v. 16, p. 153-161.

*-1935, The Gold Hill Mining district, Utah : U. S. Geol. Survey Prof. Paper 177, p. 39-42. Maps, scale $1: 24,000$ and $1: 62,500$.

Palmer, J. T., 1931, Outline of the geology of Idaho: Geog. Soc. Philadelphia Bull., v. 29, no. 4, p. 55-61 (299-305). 
Pardee, J. T., 1913, Coal in the Tertiary lake beds of southwestern Montana: U. S. Geol. Survey Bull. 531, p. 229-244.

- 1913, Some further discoveries of rock phosphate in Montana: U. S. Geol. Survey Bull. 530, p. 285-291. Map, scale 1 in. to $12 \mathrm{mi}$.

*_ 1917, The Garrison and Philipsburg phosphate fields, Montana: U. S. Geol. Survey Bull. 640, p. 195-228. Map, scale 1 : 125,000.

*_ 1921, Phosphate rock near Maxville, Granite County, Mont. : U. S. Geol. Survey Bull. 715-J, p. 141-145. Map, scale 1: 125,000.

*__ 1936, Phosphate rock near Maxville, Philipsburg, and Avon, Mont. : U. S. Geol. Survey Bull. 847-D, p. 175-188. Maps, scale 1 in. to $1 \mathrm{mi}$.

* Pardee, J. T., and Schrader, F. C., 1933, Metalliferous deposits of the greater Helena mining region, Montana: U. S. Geol. Survey Bull. 842, 318 p. Map, scale $1: 250,000$.

Peale, A. C., 1879, Jura-Trias section of southeastern Idaho and western Wyoming: U. S. Geol. and Geog. Survey Terr. (Hayden) Bull., v. 5, p. 119-123. 1893, The Paleozoic section in the vicinity of Three Forks, Mont.: U. S. Geol. Survey Bull. 110, p. 32-43. Map, scale 1: 250,000.

Peck, R. E., 1940, Lower Cretaceous Rocky Mountain nonmarine microfossils: Jour. Paleontology, v. 15, p. 285-304, 1941 ; abs., Geol. Soc. America Bull., v. 51, no. 12, pt. 2, p. 1974, 1940.

Perry, E. S., 1934, Physiography and ground-water supply in the Big Hole Basin, Montana: Mont. Bur. Mines and Geology Mem. 12, pl. 3 and explanation. Map, scale 1 in. to $8 \mathrm{mi}$.

- 1945, Distribution of sedimentary rocks in Montana and the northwestern Great Plains : Mont. Bur. Mines and Geology Misc. Contrib. 8, p. 8 and map facing correlation chart at end.

I'etersen, O. A., and Kay, J. L., 1931, The upper Uinta formation of northeastern Utah : Carnegie Mus. Annals, v. 20, nos. 3-4, p. 293-306.

Petersen, William, 1914, Phosphate deposits in the Mississippian rocks of northern Utah : Science, new ser., v. 40, p. 755-756.

*Pickering, W. X., and Dorn, C. L., 1948, Rangely oil field, Rio Blanco County, Colo.; in Structure of typical American oil fields, v. 3, p. 132-152 : Tulsa, Okla., Am. Assoc. Petroleum Geologists.

*Pierce, W. G., 1948, Geologic and structure-contour map of the Basin-Greybull area, Big Horn County, Wyo.: U. S. Geol. Survey Oil and Gas Inv. Prelim. Map 77. Scale 1 in. to $4,000 \mathrm{ft}$.

*Pierce, W. G., and Andrews, D. A., 1941, Geology and oil and coal resources of the region south of Cody, Park County, Wyo.: U. S. Geol. Survey Bull. 921, p. 110, 160. Map, scale $1: 63,360$.

Piper, A. M., 1924, Possibilities of petroleum in Power and Oneida Counties, Idaho: Idaho Bur. Mines and Geology Pamph. 12, 24 p. Maps, scale 1 in. to 2 mi.

Read, C. B., 1930, Fossil floras of Yellowstone National Park ; Pt I, Coniferous woods of Lamar River flora: Carnegie Inst. Wash., Pub. 416, p. 1-19.

*Reeside, J. B., Jr., 1923, Notes on the geology of Green River Valley between Green River, Wyo., and Green River, Utah: U. S. Geol. Survey Prof. Paper 132-C, p. 35-50.

1944, Maps showing thickness and general character of the Cretaceous deposits in the western interior of the United States: U. S. Geol. Survey Oil and Gas. Inv., Prelim. Map 10. Scale 1 in. to $171 \mathrm{mi}$.

Redden, R. E., and Crawford, A. L., 1935, Two basal Cambrian sections west of Morgan, Utah [abs.] : Utah Acad. Sci. Proc. v. 12, p. 169. 
*Reeves, Frank, 1924, Geology and possible oil and gas resources of the faulted area south of the Bearpaw Mountains, Mont.: U. S. Geol. Survey Bull. 751, p. 71-114, 5 pls. Map, scale $1: 125,000$.

*__ 1931, Geology of the Big Snowy Mountains, Mont.: U. S. Geol. Survey Prof. Paper 165, p. 143. Map, scale 1 in. to $2 \mathrm{mi}$.

Resser, C. E., 1929, Cambrian geology of the Rocky Mountains : Smithsonian Inst. Explor. and Fieldwork, p. 21-26.

- 1930, Further studies of Cambrian geology of the Rocky Mountains : Smithsonian Inst. Explor. and Fieldwork, p. 23-36.

1939, Ptarmigania strata of the northern Wasatch Mountains: Smithsonian Misc. Coll., v. 98, no. 24, p. 1-72.

1939, The Spence shale and its fauna (Utah and Idaho): Smithsonian Misc. Coll., v. 97, no. 12, p. 1-29.

- Richards, R. W., 1911, Notes on lead and copper deposits in the Bear River Range, Idaho and Utah: U. S. Geol. Survey Bull. 470, pt. 1, p. 177-187.

* Richards, R. W., and Mansfield, G. R., 1911, Preliminary report on a portion of the Idaho phosphate reserve: U. S. Geol. Survey Bull. 470, p. 371-439. Maps, scale 1 in. to $1 \mathrm{mi}$., and 1 in. to $71 / 2 \mathrm{mi}$.

*_ 1912, The Bannock overthrust; a major fault in southeastern Idaho and northeastern Utah : Jour. Geology, v. 20, p. 681-709.

*_ 1914, Geology of the phosphate deposits northeast of Georgetown, Idaho: U. S. Geol. Survey Bull. 577, 76 p. Maps, scales 1 in. to $1 \mathrm{mi}$., 1 in. to $4 \mathrm{mi}$.

* Richards, R. W., and Pardee, J. T., 1925, The Melrose phosphate field, Montana : U. S., Geol. Survey Bull. 780, p. 1-32. Map, scale 1: 62,500.

* Richardson, G. B., 1913, The Paleozoic section in northern Utah: Am. Jour. Sci., 4th ser., v. 36, no. 214, p. 406-416.

- 1941, Geology and mineral resources of the Randolph quadrangle, UtahWyo.: U. S. Geol. Survey Bull. 923, 54 p. Map, scale 1: 125,000.

* Richmond, G. M., 1945, Geology of the northwest end of the Wind River Mountains, Sublette County, Wyo.: U. S. Geol. Survey Oil and Gas Inv. Prelim. Map 31. Scale, 1 in. to $1 \mathrm{mi}$.

* Rogers, C. P., Jr., Gardner, L. S., and Hadley, H. D., 1945, Maps showing thickness and general distribution of Mesozoic and Paleozoic rocks in southcentral Montana: U. S. Geol. Survey Oil and Gas Inv. Prelim. Map 43. Scale, 1 in to $21 \mathrm{mi}$.

* Rogers, C. P., Jr., Richards, P. W., and Conant, L. C., 1948, Geology of the Worland-Hyattville area, Big Horn and Washakie Counties, Wyo.: U. S. Geol. Survey Oil and Gas Inv. Prelim. Map 84. Scale 1 in. to 4,000 ft.

Ross, C. P., 1927, Some features of the Paleozoic stratigraphy of Idaho [abs.] : Wash. Acad. Sci. Jour., v. 17, p. 125.

— 1928, Mesozoic and Tertiary granite rocks in Idaho : Jour. Geology, v. 36 , p. 673-693, map.

— 1928, Salient features of geology of south-central Idaho [abs.]: Wash. Acad. Sci. Jour., v. 18, p. 267-268.

* 1934, Correlation and interpretation of Paleozoic stratigraphy in southcentral Idaho: Geol. Soc. America Bull., v. 45, p. 994-996, 999-1000, fig. 2.

*__ 1934, Geology and ore deposits of the Casto quadrangle, Idaho: U. S. Geol. Survey Bull. 854, p. 35.

*__ 1937, Geology and ore deposits of the Bayhorse region, Custer County, Idaho: U. S. Geol. Survey Bull. 877, p. 10.

* Roth, Robert, 1932, Evidence indicating the limits of Triassic in Kansas, Oklahoma, and Texas: Jour. Geology, v. 40, p. 709.

Rouse, J. T., 1940, Structural and volcanic problems in the southern Absaroka Mountains, Wyo.: Geol. Soc. America Bull., v. 51, p. 1413-1428. 
Russell, I. C., 1902, Geology and water resources of the Snake River plains of Idaho : U. S. Geol. Survey Bull. 199, 192 p.

* Sahinen, U. M., 1937, Phosphate rock in Montana, in Glueck Auf, v. 2, no. 3, p. 10-11: Butte, Mont.

- 1950, Geology and ore deposits of the Highlands Mountains, southwestern Montana: Mont. Bur. Mines and Geology Mem. 32, 63 p. Map, scale 1 in. to $1 \mathrm{mi}$.

- Schereschewsky, Ph., 1947, Les mines de phosphate des Montagnes Rocheuses: Ann. Mines Mém., tome 136, livr. 1, p. 69-83.

- Schneider, Hyrum, 1919, General geology of Utah, in Mineral Industry of Utah: Utah Univ. Bull., v. 10, no. 11 (Eng. Sta., Dept. Metall. Research Bull. 12), p. 3-33, 89-91.

*_ 1925, A discussion of certain geologic features of the Wasatch Mountains : Jour. Geology, v. 33, p. 28-48.

1929, Structure and stratigraphy at the junction of the Wasatch Mountains with the Wasatch Plateau [abs.]: Geol. Soc. America Bull., v. 40, p. 89 ; Pan-Am. Geologist, v. 51, p. 80 ; Utah Acad. Sci. Proc., v. 7, p. 69, 1930. 1940, Epochs of volcanism in the Salt Lake City region [abs.] : Geol. Soc. America Bull., v. 51, no. 12, pt. 2, p. 2031.

- Schoff, S. L., 1951, Geology of the Cedar Hills, Utah: Geol. Soc. America Bull., v. 62, p. 619-646. Map, scale 1 in. to $2 \mathrm{mi}$.

Schuchert, Charles, 1923, Sites and nature of the North American geosynclines: Geol. Soc. America Bull., v. 34, p. 184-187.

*ـ 1933, Correlation of more important marine Permian sequences: Geol. Soc. America Bull., v. 46, p. 1-46, 1935 ; abs. Pan-Am. Geologists, v. 60, p. 240, 1933 ; Internat. Geol. Cong., 16th sess., United States, 1933 Rept., v. 1, p. 701, 1936.

- Schultz, A. R., 1918, A geologic reconnaissance for phosphate and coal in southeastern Idaho and western Wyoming: U. S. Geol. Survey Bull. 680, 84 p. Maps, various scales.

* 1918, A geologic reconnaissance of the Uinta Mountains, northern Utah, with special reference to phosphate: U. S. Geol. Survey Bull. 690, p. 31-94. Maps, scales 1 in. to 7 miles, 1 in. to $24 \mathrm{mi}$.

*_ 1920, Oil possibilities in and around Baxter Basin, in the Rock Springs uplift, Sweetwater County, Wyo.: U. S. Geol. Survey Bull. 702, p. 79-82, 101-103, pl. 1 and charts facing p. 36 and 82. Map, scale $1: 250,000$.

*_ 1941, Geology and geography of a portion of Lincoln County, Wyo.: U. S. Geol. Survey Bull. 543, p. 42-45, 131-134. Map, scale 1: 125,000.

- Schultz, A. R., and Richards, R. W., 1913, A geologic reconnaissance in southeastern Idaho: U. S. Geol. Survey Bull. 530, p. 267-284. Map, scale 1 in. to 71/2 mi.

- Scott, H. W., 1935, Some Carboniferous stratigraphy in Montana and northwestern Wyoming: Jour. Geology, v. 43, no. 8, pt. 2, p. 1011-1032.

1935, Upper Mississippian and Lower Pennsylvanian stratigraphy in Montana [abs.] : Geol. Soc. America Proc. 1934, p. 367.

1938, Eocene glaciation in southwestern Montana: Jour. Geology, v. 46, p. 628-636.

- 1945 Age of the Amsden formation [Wyo.-Mont.] [abs.]: Geol. Soc. America Bull., v. 56, no. 12, pt. 2, p. 1195.

1945, Pennsylvanian stratigraphy in Montana and northern Wyoming [abs.] : Geol. Soc. America Bull., v. 56, no. 12, pt. 2, p. 1196. 
- Sears, J. D., 1924, Geology and oil and gas prospects of part of Moffat County, Colo., and southern Sweetwater County, Wyo.: U. S. Geol. Survey Bull. 751, p. 283-284, 314-318. Map, scale $1: 125,000$.

1924, Relations of the Browns Park formation and the Bishop conglomerate and their role in the origin of the Green and Yampa Rivers: Geol. Soc. America Bull., v. 35, p. 279-304; abs., v. 35, no. 1, p. 93 ; Pan-Am. Geologist, v. 41, p. 146. Maps, no scales given.

- 1925, Geology and oil and gas prospects of part of Moffat County, Colo., and southern Sweetwater County, Wyo.: U. S. Geol. Survey Bull. 751, p. 269-319.

1926, Geology of the Baxter Basin gas field, Sweetwater County, Wyo.: U. S. Geol. Survey Bull. 781, p. 17.

Sears, J. D., and Bradley, W. H., 1924, Relations of the Wasatch and Green River formations in northwestern Colorado and southern Wyoming: U. S. Geol. Survey Prof. Paper 132, p. 93-107.

Sharkey, H. H. R., Love, J. D., and Kirby, Jewell, 1944, Map of Wyoming showing test wells for oil and gas, anticlinal axes, and oil and gas fields: U. S. Geol. Survey Oil and Gas Inv. Prelim. Map 19. Scale, 1:500,000.

- Sharkey, H. H. R., Zapp, A. D., and Johnson, C. O., 1946, Geologic and structure-contour map of Sage Creek dome, Fremont County, Wyo.: U. S. Geol. Survey, Oil and Gas. Inv. Prelim. Map 53. Scale, 2 in. to $1 \mathrm{mi}$.

- Sielaff, R. L., 1940, Oil fields of the Ferris-Lost Soldier district, Carbon County, Wyo. : Kans. Geol. Soc. Guidebook 14, p. 161-162.

Sinclair, W. J., and Granger, Walter, 1911, Eocene and Oligocene of the Wind River and Big Horn Basins [Wyo.] : Am. Mus. Nat. History Bull. 30, p. 83-117.

-_ 1912, Notes on the Tertiary deposits of the Big Horn Basin: Am. Mus. Nat. History Bull. 31, p. 57-67.

Sinkler, Helen, 1942, Geology and ore deposits of the Dillon nickel prospect, southwestern Montana: Econ. Geology, v. 37, p. 136-152. Map, scale 1 in. to about $2400 \mathrm{ft}$.

Sloss, L. L., 1939, Stratigraphy and insoluble residues of the Madison group of Montana [abs.] : Geol. Soc. America Bull., v. 50, no. 12, pt. 2, p. 1959-1960.

1950, Paleozoic sedimentation in Montana area: Am. Assoc. Petroleum Geologists Bull., v. 34, no. 3, p. 423-451.

Sloss, L. L., and Hamblin, R. H., 1942, Stratigraphy and insoluble residue of Madison group [Mississippian] of Montana: Am. Assoc. Petroleum Geologists Bull., v. 26, p. 305-325.

Sloss, L. L., and Laird, W. M., 1946, Devonian stratigraphy of central and northwestern Montana: U. S. Geol. Survey Oil and Gas Inv. Prelim. Chart 25.

- 1947, Devonian system in central and northwestern Montana: Am. Assoc. Petroleum Geologists Bull., v. 31, p. 1404-1430.

Sloss, L. L., and Moritz, C. A., 1951, Paleozoic stratigraphy of southwestern Montana: Am. Assoc. Petroleum Geologists Bull., v. 35, p. 2135-2169.

Smith, J. P., 1901, The border line between Paleozoic and Mesozoic in western America: Jour. Geology, v. 9, p. 512-521.

1004, The comparative stratigraphy of the marine Trias[sic] of western America : Calif. Acad. Sci. Proc. 3d ser., v. 1.

* Spence, H. S., 1920, Phosphate in Canada: Canada Mines Br. Pub. No. 396, p. 104-105.

Spieker, E. M., 1930, Bituminous sandstone near Vernal, Utah: U. S. Geol. Survey Bull. 822, p. 77-98.

- 1949, Sedimentary facies and associated diastrophism in the Upper Cretaceous of central and eastern Utah: Geol. Soc. America Mem. 39, p. 55-81. 
* Stearns, H. T., and Bryan, L. L., 1925, Preliminary report on the geology and water resources of the Mud Lake Basin, Idaho: U. S. Geol. Survey Water Supply Paper 560, p. 92.

Stillman, F. B., 1928, A reconnaissance of the Wasatch front between Alpine and American Fork Canyons, Utah: Jour. Geology, v. 36, p. 44-45. Map, scale $1: 31,250$.

- Stipp, T. F., 1947, Paleozoic formations near Cody, Park County, Wyo.: Am. Assoc. Petroleum Geologists Bull., v. 31, p. 274-281.

1947, Paleozoic formations of the Big Horn Basin, Wyo.: Wyo. Geol. Assoc. Guidebook 2.

1952, Paleozoic formations of the Big Horn Basin: Wyo. Geol. Assoc. Guidebook 7, p. 22-25.

- Stipp, T. F., and French, H. F., 1945, Geologic and structure map of the Little Buffalo Basin oil and gas field and vicinity, Park and Hot Springs Counties, Wyo. : U. S. Geol. Survey. Scale, 1 in. to $2 \mathrm{mi}$.

- Stone, R. W., and Bonine, C. A., 1914, The Elliston phosphate field, Montana : U. S. Geol. Survey Bull. 580, p. 373-383. Map, scale 1 in. to $1 \mathrm{mi}$.

Stow, M. H., 1939, Dating sedimentation, volcanism, and orogeny in Beartooth Mountain region by heavy minerals [abs.] : Geol. Soc. America Bull., v. 50, no. 12, pt. 2, p. 1937-1938.

1952, Results of some heavy mineral studies in the Big Horn Basin, Mont. and Wyo.: Wyo. Geol. Assoc. Guidebook 7, p. 80-88.

Swartz, C. K., and others, 1942, Correlation of Silurian formations of North America : Geol. Soc. America Bull., v. 53, p. 533-538.

* Swenson, F. A., 1942, Geology of the northwest flank of the Gros Ventre Mountains, Wyo.: Iowa Univ. unpub. dissert., 100 p.; abs., Iowa Univ. Pub., Aims and Prog. Research Ser. no. 71, 1 p., unnumbered. Map, scale 1 in. to $13 / 7 \mathrm{mi}$.

Talmadge, J. E., 1901, Geology of Utah : Internat. Min. Cong, 4th, Proc., p. 42-48.

* Tansley, Wilfred, Schafer, P. A., and Hart, L. H., 1933, A geological reconnaissance of the Tobacco Root Mountains, Madison County, Mont. : Mont. Bur. Mines and Geology Mem. 9, 57 p. Map, scale 1 in. to $2 \frac{1 / 2}{\mathrm{mi}}$.

* Telfer, L., 1933, Phosphate in the Canadian Rockies: Canadian Inst. Mining and Metallurgy Trans., v. 36, p. 566-605 [1934] ; Bull., 260 p. 566-605.

* Thom, W. T., Jr., 1923, Oil and gas prospects in and near the Crow Indian Reservation, Mont. : U. S. Geol. Survey Bull. 736, p. 41.

* Thom, W. T., Jr., and Spieker, E. M., 1931, The significance of geologic conditions in Naval Petroleum Reserve No. 3, Wyo.: U. S. Geol. Survey Prof. Paper 163, p. 16, 24.

- Thom, W. T., Jr., and others, 1935, Geology of Big Horn County and the Crow Indian Reservation, Mont., with special reference to the water, coal, oil, and gas resources: U. S. Geol. Survey Bull. 856, p. 39.

- Thomas, C. R., and others, 1944, Structure contour map of the Rangley anticline, Rio Blanco and Moffat Counties, Colo. : U. S. Geol. Survey Oil and Gas Inv. Prelim. Map 7.

- 1945, Structure contour maps of the Rangley anticline, Rio Blanco and Moffat Counties, Colo.: U. S. Geol. Survey Oil and Gas Inv. Prelim. Map 41.

* Thomas, C. R., McCann, F. T., and Raman, N. D., 1945, Mesozoic and Paleozoic stratigraphy in northwestern Colorado and northeastern Utah: U. S. Geol. Survey Oil and Gas Inv. Prelim. Chart 16.

- Thomas, Horace D., 1932, The stratigraphic relations of the Permian rocks of central and southeastern Wyoming [abs.] : Colo.-Wyo. Acad. Sci. Jour., v. 1, no. 4 , p. 34 .

- 1933, Character of producing standstones and limestones of Wyoming and Montana [discussion] : Am. Assoc. Petroleum Geologists Bull., v. 17, p. 268-269. 
* Thomas, Horace D., 1933, Further contributions on the Embar and related formations of south-central Wyoming [abs.] ; Col.-Wyo. Acad. Sci. Jour., v. 1, no. 5, p. 36-37.

*__ 1934, A Phosphoria faunule from the "Embar" red beds [abs.] : Colo.Wyo. Acad. Sci. Jour., v. 1. no. 6, p. 34.

* 1934, Phosphoria and Dinwoody tongues in Lower Chugwater of central and southeastern Wyoming: Am. Assoc. Petroleum Geologists Bull., v. 18, p. $1655-1697$.

*_ 1935, The brachiopod Punctospirifer pulchra (Meek) : Am. Midland Naturalist, v. 16, no. 2, p. 203-207.

*__ 1939, "Park City" beds on southwest flank of Uinta Mountains, Utah, [Comment by J. Stewart Williams] : Am. Assoc. Petroleum Geologistsi Bull., v. 23, p. 1249-1250.

* - 1940, Pennsylvanian and Permian stratigraphy of central and southeastern Wyoming: Kans. Geol. Soc. Guidebook 14, p. 120-125.

* 1948, Summary of Paleozoic stratigraphy of the Wind River Basin, Wyo.: Wyo. Geol. Soc. Guidebook 3, p. 79-95.

*_ 1949, The geological history and geological structure of Wyoming: Wyo. Geol. Survey Bull., 42, p. 19-23, 1949, abs., Regional stratigraphy and structure of Wyoming, Oil and Gas Jour., v. 46, p. 113.

*_ 1950, Summary of the Paleozoic stratigraphy of the Green River Basin, Wyo.: Wyo. Geol. Assoc. Guidebook 5, p. 17-24.

1952, Cambrian and Ordovician stratigraphy around the Southern Big Horn Basin, Wyo.: Wyo. Geol. Assoc. Guidebook 7, p. 32-36.

Thomas, Horace D., and Krueger, M. L., 1942, Late Paleozoic and early Mesozioic stratigraphy of Uinta Mountains, Utah: Am. Assoc. Petroleum Geologists Bull., v. 30, p. 1255-1293, 1946 ; abs. v. 26, p. 916-917 [1942] ; v. 30, p. 131-132 [1946].

Thompson, M. L., 1945, Pennsylvania rocks and fusulinids of east Utah and northwest Colorado correlated with Kansas section: Kansas Univ. Geol. Survey Bull. 60, pt. 2, p. 17-84.

Thompson, M. L., and Bissell, H. J., 1940, Pennsylvanian and Permian fusulinids of the Wasatch Mountains, Utah [abs.] : Oil and Gas Jour., v. 38, no. 48, p. 67 .

* Thompson, M. L., and Scott, H. W., 1941, Fusulinids from the type section of the Lower Pennsylvanian Quadrant formation [Wyo.] : Jour. Paleontology, v. 15, p. 349-353.

* Thompson, W. O., and Kirby, J. M., 1940, Cross sections from Colorado Springs to Black Hills showing correlation of Paleozoic stratigraphy: Kans. Geol. Soc. Guidebook 14, p. 142-146.

Tomalinson, C. W., 1917, The middle Paleozoic stratigraphy of the central Rocky Mountain region: Jour. Geology, v. 25, p. 112-134, 244-257, 373-394.

Tourtelot, H. A., 1946, Tertiary stratigraphy in the northeastern part of the 'Wind River Basin, wyo. : v. s. Geol. Survey, Oil and Gas Inv., Prelim. Chart 22.

1952, Marine and evaporite facies of Permian and Triassic strata in the southern part of the Big Horn Basin and adjacent areas, central Wyoming: Wyo. Geol. Asso. Guidebook 7, p. 49-52.

* Tourtelot, H. A., Thompson, R. M., and DeWitt, W. Jr., 1948, Geology of the Boysen area, central Wyoming: U. S. Geol. Survey Oil and Gas. Inv. Prelim. Map 91, 2 sheets. Scale, 1 in, to $3 / 4 \mathrm{mi}$.

Trowbridge, R. M., 1931, Physical analyses of the Chugwater formation [abs.] : Geol. Soc. America Bull., v. 42, p. 332.

* Trumbull, L. W., 1917, Petroleum geology of Wyoming: 81 p., Cheyenne, Wyo. G. G. Bovee. 
* Unterman, G. E., and Unterman, B. R., 1949, Geology of Green and Yampa River Canyons and vicinity, Dinosaur National Monument, Utah and Colo.: Am. Assoc. Petroleum Geologists Bull., v. 33, p. 683-694.

- University of Idaho Phosphate Committee, 1938, University of Idaho and development of Idaho phosphates [progress report] : Idaho Univ. Bull., v. 33, no 2.

* Uren, L. C., 1938, Economics and geology of the Rocky Mountain area : World Petroleum, v. 9, no. 8, p. 34-49; no. 9, p. 50-64; no. 10, p. 46-62.

Van Houten, F. B., 1944, Stratigraphy of the Willwood and Tatman formations in.northwestern Wyoming: Geol. Soc. America Bull., v. 55, p. 165-210.

*___ 1950, Geology of the western part of the Beaver Divide area, Fremont County, Wyo.: U. S. Geol. Survey Oil and Gas Inv. Map OM 113. Scale $1: 31,680$.

- 1952, Sedimentary record of Cenozoic orogenic and erosional events, Big . Horn Basin, Wyo.: Wýo. Geol. Assoc. Guidebook 7, p: 74-79.

Veatch, A. C., 1906, Coal' and oil in southern Uinta County, Wyo.: U. S. Geol. Survey Bull. 285, p. 331-353. Map, scale 1 in. to 5 mi.

* 1907, Geography and geology of a portion of southwestern. Wyoming, with special reference to coal and oil: U. S. Geol. Survey Prof. Paper 56, p. 50, chart facing p. 50, pls. 4, 5. Map, scale $1: 125,000$.

* Ver Wiebe, W. A., 1930, Oil fields in the United States : p. 447-558, New York, McGraw-Hill Book Co.

*__ 1949, Oil fields in North America : 251 p., Wichita Kans., Edward Bros.

Vine, J. D. and Erdman, C. E., 1952, Records of wells drilled for oil and gas in Montana : U. S. Geol. Survey Circ. 172, 39 p.

* Waggaman, W. H., 1927, Phosphoric acid, phosphate and phosphatic fertilizer : Am. Chem. Soc. Mono. Series, no. 34:

Walcott, C. D., 1908-1910, Cambrian geology and paleontology, Pt. II, Nos. 1-7 : Smithsonian Misc. Coll., v. 53, 431 p.

Walter, H. G., 1931, The Dinwoody formation of western Wyoming [abs.] : Geol. Soc. America Bull., v. 42, p. 329.

* Walton, P. T., 1944, Geology of the Cretaceous of the Uinta Basin, Utah : Geol. Soc. America Bull., v. 55, p. 91-130. Map, scale 1 in. to $81 / 2 \mathrm{mi}$.

*__ 1947, Orégon Basin oil and gas field, Park County, Wyo.: Am. Assoc. Petroleum: Geologists Bull., v. 31, p. 1431-1453; abs., Am. Assoc. Petroleum Geologists - Soc. Econ. Paleontologists and Mineralogists - Soc. Econ. Geophysicists Joint Ann. Mtg., Los Angeles, March 24-30 Program, pp. 28-29.

Wanless, H. R., Bachrock, Ruth, and Zeller, Edward, 1945, Upper Mississippian and Pennsylvanian stratigraphy of part of western Wyoming [abs.] : Geol. Soc. America Bull., v. 56, no. 12, pt. 2, p. 1210-1211.

Wanless, H. R., Belknap, R. L., and Foster, Helen, 1946, Paleozoic and Mesozoic columns in the Gros Ventre, Teton, Hoback, Wyoming, and Snake River Ranges, Wyo. [abs.] : Geol. Soc. America Bull., v. 57, no. 12, pt. 2, p. 1240.

Warren, P. S., 1927, Banff area, Alberta: Canada, Geol. Survey Mem. 153, 94 p., (no. 2121).

* Washburne, C. W., 1908, Gas fields of the Bighorn Basin, Wyo.: U. S. Geol: Survey Bull., 340, p. 349 .

Weart, R. C., 1947, Geology of the northern flank of the Wind River Mountains, Wyo. [abs.] : Geol. Soc. America Bull., v. 58, no. 12, pt. 2, p. 1238-1239.

* Weeks, F. B., 1907, Stratigraphy and structure of the Uinta Range: Geol. Soc America Bull., v. 18, p. $427-448$. Map, scale 1 in. to $16 \mathrm{mi}$.

* Weeks, F. B., and Ferrier, W. F., 1907, Phosphate deposits in western United States: U. S. Geol. Survey Bull. 315, p. 449-462, 1906; abs., Science, new ser., v. 25, p. 620-621. Map, scale 1 in. to $16 \mathrm{mi}$. 
Weeks, F. B., and Herkes, V. C., 1908, Notes on the Fort Hall mining district, Idaho: U. S. Geol. Survey Bull. 340, p. 175-182.

Weller, J. M., and others, 1948, Correlation of Mississippian formations of North America : Geol. Soc. America Bull., v. 59, p. 91-196.

Westgate, L. G., and Branson, E. B., 1913, The later Cenozoic history of the Wind River Mountains, Wyo. : Jour. Geology, v. 21, p. 142-159.

-Westoll, T. S., 1941, The age of certain Permian fish-bearing strata: Geol. Mag., v. 78, p. 37-44.

White, C. A., 1880, Paleontologic Papers No. 9, Fossils of the Jura-Trias of southeastern Idaho: U. S. Geol. and Geog. Survey. Terr. Bull., v. 5, p. 105-117.

1889, On the geology and physiography of a portion of northwestern Colorado and adjacent parts of Utah and Wyoming: U. S. Geol. Survey 9th Ann. Rept., p. 677-717. Map, scale 1 in. to $13 \mathrm{mi}$.

1895, The Bear River formation and its characteristic fauna: U. S. Geol. Survey Bull. 128, 108 p.

* White, C. David, 1923, Permian of western America from the paleobotanical standpoint: Pan-Pacific Sci. Cong., Australia, 1923, Proc. v. 2, p. 1050-1077. 1924.

Wilcox, R. E., 1944, Rhyolite-basalt complex on Gardiner River, Yellowstone Park, Wyo.: Geol. Soc. America Bull., v. 55, p. 1047-1079.

Williams, J. Steele, 1936, Carboniferous formations in the northern Blue Springs Hills, near Malad, Idaho [abs.] : Geol. Soc. America Proc. 1935, p. 373.

* 1936, Stratigraphic sections and faunules of some western Carboniferous formations at or near the type localities [abs.]: Geol. Soc. America Proc. 1935, p. 118.

- 1948, Mississippian-Pennsylvanian boundary problems in the Rocky Mountain region: Jour. Geology, v. 56, p. 327-351; abs., v. 58, p. 1280, 1947.

*Williams, J. Stewart, 1939, Phosphate in Utah : Utah Agr. Exper. Sta. Bull. 290, 44 p. Maps, 1 in. to about $2 \mathrm{mi}$.

*— 1939, "Park City" beds on southwest flank of Uinta Mountains, Utah : Am. Assoc. Petroleum Geologists Bull., v. 23, p. 82-100.

*__ 1943, Carboniferous formations of the Uinta and northern Wasatch Mountains, Utah : Geol. Soc. America Bull., v. 54 p. 615-622.

- 1945, Nomenclature of Triassic rocks in northeastern Utah ! Am. Jour. Sei., v. 243, no. 9, p. $473-479$.

1946, Sedimentary succession in the Logan quadrangle, Utah and vicinity : mimeographed paper and printed map, Logan, Utah State Agr. Coll.

* 1948, Geology of the Paleozoic rocks, Logan quadrangle, Utah: Geol. Soc. America Bull., v. 59, p. 1121-1164. Map, scale 1 : 125,000.

- 1949, Carboniferous and Permian rocks [Utah], in Oil and gas possibilities of Utah, p. 75-76: Utah Geol. Miner. Survey.

* Williams, J. Stewart, and Hanson, A. M., 1942, Phosphate reserves of Utah (revised estimate) : Agr. Exper. Sta., Utah State Agr. Coll. Bull. 304, 23 p. Maps, scales about 1 in. to $61 / 2 \mathrm{mi}$., 1 in. to about $71 / 2 \mathrm{mi}$.

Williams, J. Stewart, and Maxey, G. B., 1941,: The Cambrian section in the Logan quadrangle, Utah, and vicinity: Am. Jour. Sci., v. 239, no. 4, p. 276-285.

williams, J. Stewart, and Yolton, J. S., 1945, Brazer [Mississippian] and lower Wells [Pennsylvanian] section at Dry Lake, Logan quadrangle, Utah : Am. Assoc. Petroleum Geologists Bull., จ. 29, p. 1143-1155.

* Williams, M. D., and Sharkey, H. H. R., 1946, Geology of the Bargee area, Fremont County, Wyo.: U. S. Geol. Survey Oil and Gas Inv. Prelim. Map 56. Scale 1 in. to $2 \mathrm{mi}$. 
* Williams, N. C., 1940, Summary of Wasatch Mountain geology : Compass, v. 20, p. 75-78.

* Willis, Bailey, 1912, Index to the stratigraphy of North America: U. S. Geol. Survey Prof. Paper 71, p. 485-86, 494-495.

- Wilmarth, M. G., 1938, Lexicon of geologic names of the United States: U. S. Geol. Survey Bull. 896, pts. 1, 2, p. 683, 1603, 1651.

*Wilson, C. W., Jr., 1934, Geology of the thrust fault near Gardiner, Mont.: Jour. Geology, v. 42, p. 649-663. Map, scale 1 in. to about $13 / 8 \mathrm{mi}$.

- 1934, Section of Paleozoic and Mesozoic rocks measured at Cinnabar Mountain, Park County, Mont., and at Mount Everts, Yellowstone National Park, Wyo.: Am. Assoc. Petroleum Geologists Bull., v. 18, p. 372.

- Winchell, A. N., 1914, Mining districts of the Dillon quadrangle, Mont., and adjacent areas: U. S. Geol. Survey Bull. 574, p. 26 ; abs., Wash. Acad. Sci. Jour., v. 5, p. 23, 1915. Maps, various scales.

* Winchester, D. E., 1919, Oil shales : Franklin Inst. Jour., v. 187, no. 6, p. 689-703.

1.923, Oil shale of the Rocky Mountain region: U. S. Geol. Survey Bull. 729, p. 20, 76-79, 82-87, 90-91, 127-129.

Wood, H. E., 2d, 1938, Continental Cenozoic at Three Forks, Mont. [abs.] : Geol. Soc. America Proc. 1937, p. 291-292.

1941, Wyoming Eocene correlation [abs.] : Geol. Soc. America Bull., v. 52, no. 12, pt. 2, p. 1991.

- Woodruff, E. G., 1909, Sulphur deposits near Thermopolis, Wyo.: U. S. Geol. Survey Bull. 380, p. 373-380.

1911, The Lander oil field, Fremont County, Wyo. : U. S. Geol. Survey Bull. 452, p. 10-14. Map, scale $1: 63,360$.

* Wyoming Geological Association, 1950, Wyoming, a stratigraphic nomenclature chart: Wyo. Geol. Assoc. Guidebook 5.

* Wyoming University, Wyoming Geological Association, and Yellowstone-Bighorn Research Association, 1947, guidebook, Field conference in the Bighorn Basin [Mont.-Wyo.], August 5-8, 1947, 277 p.

Yen, T. C., 1945, Late Tertiary fresh-water mollusks of southeastern Idaho [abs.] : Geol. Soc. America Bull., v. 56, no. 12, pt. 2, p. 1214.

1946, Late Tertiary fresh-water mollusks from southeastern Idaho: Jour. Paleontology, v. 20, p. 485-494.

- 1946, On Lower Cretaceous fresh-water mollusks of Sage Creek, Wyo.: Acad. Nat. Sci. Philadelphia Notulae Naturae 166, 13 p.

- 1947, Pliocene fresh-water mollusks from northern Utah : Jour. Paleontology, v. 21, p. 268-277.

* Ziegler, Victor, 1916, The Pilot Butte oil field, Fremont County : Wyo. Geologist's Office Bull. 13, p. 142-178. Map, scale 1 in. to 2,000 ft.

\section{REGIONAL STRUCTURE}

Agatson, R. S., 1952, Tensleep formation of the Big Horn Basin : Wyo. Geol. Assoc. Guidebook 7, p. 44-48.

Anderson, A. L., 1934, A preliminary report on recent block faulting in Idaho: Northwest Sci., v. 8, no. 2, p. 17-28.

1947, Role of the Idaho batholith during the Laramide orogeny [abs.]: Geol. Soc. America Bull., v. 58, no. 12, pt. 2, p. 1162.

1952, Multiple emplacement of the Idaho batholith: Jour. Geology, v. 60, no. 3, p. 255-265.

Andrews, D. A., Pierce, W. G., and Eargle, D. H., 1947, Geologic map of the Big Horn Basin, Wyo. and Mont., showing terrace deposits and physiographic features: U. S. Geol. Survey Oil and Gas Inv. Prelim. Map 71. Scale. 1 in. to $2 \mathrm{mi}$.

296348-54-4 
* Andrews, D. A:, Pierce, W. G., and Kirby, J. J., 1944, Structure contour map of the Big Horn Basin, Wyo. and Mont.: U. S. Geol. Survey Oil and Gas Inv. Prelim. Map 3.

* Bacon, C. S., Jr., 1941, Stratigraphy and structure of the Confusion and Conger Ranges, western Utah [abs.]: Geol. Soc. America Bull., v. 52, p. 1994.

*—_ 1948, Geology of the Confusion Range, west-central Utah: Geol. Soe. America Bull., v. 59, p. 1027-1052.

Bailey, R. W., 1927, The Bear River Range fault, Utah : Am. Jour. Sci., 5th ser., v. 13, p. 497-502.

*Baker, A. A., 1946, Geology of the.Green.River Desert-Cataract Canyon region, Emery, Wayne, and Garfièld Counties, Utah : U. S. Geol. Survey Bull. 951, p. 32-50.

* Baker, A. A., Huddle, J. W., and Kinney, D. M., 1949, Paleozoic geology of north and west sides of Uinta Basin, Utah : Am. Assoc. Petroleum Geologists Bull., v. 33, p. 1161-1197.

Baker, C. L., 1938, Westward overthrusting in Wind River Mountains, Wyo. [abs.] : Geol. Soc. America Bull., v. 49, no. 12, pt. 2, p. 1865 .

1945, Geology of the northwestern Wind River Mountains, Wyo.: Geol. Soc. America Bull., v. 57, p. 565-596.

Baker, V. R., 1942, A brief review of the physiography and structure of the Teton Range, Wyo. : Compass, v. 22, no. 3, p. 207-211.

Bass, N. W., 1946, Subsurface maps of the Rangely anticline, Rio Blanco County, Colo.: U. S. Geol. Survey Oil and Gas Inv. Prelim. Map 67. Scale 1 in. to $1 / 2 \mathrm{mi}$.

- Bauer, C. M., 1932, The geology of the southeastern part of the Wind River Basin, Wyo. [abs.] : Colo. Univ. Studies, v. 20, no. 1, 1932 ; Colo. Univ. Bull., v. 32, no. 15, p. 6-7.

* Beck, Elfred, 1929, Salt Creek oil field, Natrona County, Wyo., in Structure of typical American oil fields. v. 2, p. 589-603. Am. Assoc. Petroleum Geologists.

* Beckwith, R. H., 1941, Structure of Elk Mountain district, Carbon County, Wyo.: Geol. Soc: America.Bull., v. 52, p. 1445-1486.

Berry; G: W., 1943, Stratigraphy and structure at Three Forks, Mont. : Geol. Soc. America, Bull., v. 54, p. 1-29. Map, scale 1 in. to $2 \mathrm{mi}$.

Bevan, A. C., 1928, Cenozoic history of the Montana front ranges [abs.] : Ohio Acad. Sci. Proc. v. 8, pt. 4, p. 177, 1928 ; Ohio Jour. Sci., v. 28, no. 3, p. 155.

- 1928, Rocky Mountain front in Montana [abs.] : Geol. Soc. America Bull., v. 39, p. 160-161. ; Pan-Am. Geologist, v. 49, p. 71-72.

Bissell, H. J.; 1952, Stratigraphy and structure of Northeast Strawberry Valley quadrangle, Utah : Am. Assoc. Petroleum Geologists Bull., v. 36, no. 4, p. 575.

Blackstone, D. L., Jr., 1940, Structure of the Pryor Mountains, Mont.: Jour. Geologs, v. 48, p. 590-618.

- 1947, Montana and Wyoming examples of overthrusting in relation to petroleum accumulation [abs.]: Oil and Gas Jour., v. 45, no. 47, p. 116; Am. Assoc. Petroleum Geologists - Soc. Econ. Paleontologists and Mineralogists Soc. Econ. Geophysicists Joint Ann. Mtg., Los Angeles, March 24-27 Program, p. 25.

*__ 1948, The structural pattern of the Wind River Basin, Wyo.: Wyo. Geol. Assoc. Guidebook 3, p. 69-78.

Blackwelder, Eliot, 1915, Origin and development of the Rocky Mountains in the United States [abs.] : Assoc. Am. Geologists Ann., 5, p. 137.

1926, Earthquakes in Jackson Hole, Wyo.: Seismol. Soc. America Bull., v. 16, p. 196. 
* Boutwell, J. M., 1907, Stratigraphy and structure of the Park City mining district, Utah : Jour. Geology, v. 15, p. 434-458.

- 1912, Geology and ore deposits of the Park City district, Utah: U. S. Geol. Survey Prof. Paper 77, 231 p.

Bradley, F. H., 1873, Report on the Snake River [region] : U. S. Geol. Survey Terr. (Hayden) Ann. Rept. 6, p. 189-271. Small-scale geographic maps.

- Brainerd, A. E., 1940, Big Muddy field, Converse County, Wyo. : Kans. Geol. Soc. Guidebook 14, p. 148-149.

Bucher, W. H., 1934, Problem of the Heart Mountain thrust [abs.] : Geol. Soc. Am. Proc. 1933, p. 57.

1986, Remarkable local folding, possibly due to gravity, bearing on the Heart Mountain thrust problem [abs.] : Geol. Soc. America Proc. 1935, p. 69.

- 1940, Tectono-physics of the crust; the mountain-building cycle: Am. Geophys. Union Trans., 21st Ann. Mtg., Pt. 1, p. 163-166; discussion, p. 172-176.

— 1947, Heart Mountain problem [Wyo.]: Wyo. Geol. Assoc. Guidebook 7, p. 189-197.

- Bucher, W. H., Chamberlin, R. T., and Thom, W. T., Jr., 1833, Results of struc. tural research work in Beartooth-Big Horn region, Mont.-Wyo. : Am. Assoc. Petroleum Geologists Bull., v. 17, p. 680-693; abs., Geol. Soc. America Bull., v. 44, p. 75-77; Pan-Am. Geologist, v. 59, p. 233-234.

Bucher, W. H., Thom, W. T., Ja., and Chamberlain, R. T., 1934, Geologic problems of the Beartooth-Bighorn region; Geol. Soc. America Bull., v. 45, p. 167-188.

Burbank, W. S., and Lovering, T. S., 1933, Relation of stratigraphy, structure, and igneous activity to ore deposition of Colorado and southern .Wyoming, in Ore deposits of the Western States (Lindgren Volume), p. 272-315: Am. Inst. Min. Metall. Eng.

Burbank, W. S., and others, 1935, Geologic map of Colorado: U. S. Geol. Survey in cooperation with Colo. State Geol. Survey and Colo. Metal Mining Fund. Scale $1: 500,000$.

Butler, B. S., 1933, Summary, Pt. 1 of Ore deposits related to stratigraphic, structural, and igneous geology in the western. United States, in Ore deposits of the Western States (Lindgren Volume), p. 198-240 : Am. Inst. Min. Metall. Eng.

Buwalda, J. P., and Gutenberg, Beno, 1935, Investigation of overthrust faults by seismic methods: Science, new ser., v.:81, no. 2103, p. 384-386; abs., Geol. Soc. America Proc. 1934, p. 69.

Callaghan, Eugene, 1939, Recent fault scarps in the western part of the Great Basin.[abs.] : Geol. Soc. America Bull., v. 50, p. 1948.

Calkins, F. C., 1921, Thrust faulting in the Cottonwood district, Wasatch Mountains, Utah [abs.] : Wash. Acad: Sci. Jour., v. 11, p. 422.

*Calkins, F. C., and Butler, B. S., 1943, Geology and ore deposits of the Cottonwood-American Fork area, Utah, with sections on history and production by V. C. Heikes : U. S. Geol. Survey Prof. Paper 201, p. 22, 30-31, 89.

Campbell, M. R., and others, 1915, Guidebook of the western United States; Pt. A, The Northern Pacific route with a side trip to Yellowstone Park: U. S. Geol. Survey Bull. 611, 212 p. Maps, various scales.

Chamberlin, R. T., 1934, Geologic analysis of the gravity anomalies for the Black Hills-Bighorn-Beartooth region: Geol. Soc. America Bull., v. 46, p. 393-408, 1935 ; abs. Proc. 1933, p. 56-57.

—_ 1940, Diastrophic behavior around the Bighorn Basin : Jour. Geology, v. 48, p. 673-716.

Church, Victor, 1941, Structural geology of the central portion of the Gros Ventre Range, Wyo. [abs.] : Utah Acad. Sci. Proc., v. 18, p. 17. 
*Clapp, C. H., 1932, Geology of a portion of the Rocky Mountains of northwestern Montana: Mont. Bur. Mines and Geology Mem. 4, 30 p. Map, scale 1 in. to about $7 \mathrm{mi}$.

*Clark, F. R., 1919, Farnham anticline, Carbon County, Utah : U. S. Geol. Survey Bull. 711, p. 8, 13.

Cooley, J. L., 1946, Devonian of Bear. River Range, Utah : Utah State Agr. Coll., Logan, Utah, unpub. thesis.

Crickmay, C. H., 1931, Jurassic history of North America; its bearing on the development of continental structure: Am. Philos. Soc. Proc., v. 70, p. 15-102.

*Curtis, B. F., 1950, Structure of the north flank of the Uinta Mountains: Wyo. Geol. Assoc. Guidebook 5, p. 93-102. Map, scale 1:500,000.

Dake, C. L., 1918, The Hart Mountain overthrust and associated structures in Park County, Wyo. : Jour. Geology, v. 26, p. 44-45.

1920, Episodes in Rocky Mountain orogeny : Am. Jour. Sei., 5th ser., v. 1, p. 245-254, 1921 ; abs., Science, new ser., v. 51, p. 520-521.

Daly, R. A., 1912, Geology of the North American Cordillera at the 49th parallel : Canada Geol. Survey Mem. 38. Map, scale 1:62,500.

Davis, W. M., 1903, The mountain ranges of the Great Basin: Harvard Coll. Mus. Comp. Zoology Bull., v. 42, Geol. Ser. v. 6, no. 3, p. 129-177.

1905, The Wasatch, Canyon, and House ranges, Utah : Harvard Coll. Mus. Comp. Zoology Bull., v. 49, Geol. Ser., v. 8, no. 2, p. 17-28.

* DeFord, R. K., 1941, Permian problems [abs.] : Tulsa Geol. Soc. Digest, v. 9, p. 38-41.

Demorest, M. H., 1941, Critical structural features of the Bighorn Mountains, Wyo.: Geol. Soc. America Bull., v. 52, p. 161-176, 3 figs., 4 pls.

Denson, M. D., Jr., and Morrisey, N. S., 1952, The Madison group (Mississippian) of the Big Horn and Wind River Basins, Wyo.: Wyo. Geol. Assoc. Guidebook 7, p. 37-43.

- DeSchmid, H. S., 1916, Investigation of a reported discovery of phosphate in Alberta : Canada Mines Br. Bull. 12, 38 p.

*__ 1917, A reconnaissance for phosphate in the Rocky Mountains; and for graphite near Cranbrook, B. C.: Canada Mines Br. Summary Rept. 1916, p. 22-35.

- Dobbin, C. E., 1943, Structural conditions of oil and gas accumulation in Rocky Mountain region, United States: Am. Assoc. Petroleum Geologists Bull., จ. 27, p. 417-478.

Dobbin, C. E., Kramer, W. B., and Miller, J. C., 1944, Geologic and structure map of the Elk Basin oil and gas field and vicinity, Park County, Wyo., and Carbon County, Mont.: U. $\mathbf{s}$. Geol. Survey. Seale 1 in. to $1 / 2 \mathrm{mi}$.

Eardley, A. J., 1933, Structure and physiography of the southern Wasatch Mountains, Utah: Mich. Acad. Sci. Papers, v. 19, p. 377-400; abs., Geol. S0C. America Bull., v. 44, pt. 1, p. 83-84, 1933.

1939, Structure of the Wasatch-Great Basin region: Geol. Soc. America

Bull., v. 50, p. 1277-1310; abs., v. 49, no. 12, pt. 2, p. 1879.

-1941-43. Structure and physiography of the north-central Wasatch Mountains, Utah [abs.] : Utah Acad. Sci. Proc., v. 19-20, p. 19.

1946, Paleozoic Cordilleran geosyncline and related orogeny: Jour.

Geology, v. 55, p. 309-342, 1947 ; abs., Geol, Soc. America Bull., V. 57, p. 1189.

1947, Late Cenozoic trenches of the Rocky Mountains [U. s. and Canada]

[abs.] : Geol. Soc. America Bull., v. 58, p. 1176.

1949, Structural evolution of Utah, in The oil and gas possibilities of

Utah, p. 10-23; Utah Geol. Mineralog. Survey.

1950, Snake River region of western Wyoming: Wyo. Geol. Assoc. Guide-

book 5, p. 88-92. 
Jiardley; A. J., 1951, Structural geology of North America : 624 p., Harper \& Brothers, New York. Maps, various scales.

1951, Tectonic divisions of North America: Am. Assoc. Petroleum Geologists, v. 35, no. 10, p. 2229-2237.

Eardley, A. J., and Haas, Merrill, 1936, Oil and gas possibilities in the Great Salt Lake Basin : Utah Acad. Sci. Proc., v. 13, p. 61-80.

* Edmund, R. W., 1940, Structural geology and physiography of the northern end of the Teton Mountains, Wyo.: Iowa Univ. unpub. dissertation, 163 p. ; abs., Iowa Univ. Pub., Aims and Prog. Research Ser., No. 66. Map, scale 1 in. to $2 \mathrm{mi}$.

Engel, A. E. J., 1947, Geology of the central Owl Creek Mountains, Wyo. [abs.] : Geol. Soc. America Bull., v. 58, no. 12, pt. 2, p. 1177-1178.

* Fanshawe, J. R., 1939, Structural geology of Wind River Canyon area, Wyo.: Am. Assoc. Petroleum Geologists Bull., v. 23, p. 1439-1492. Maps, various scales.

1947, Tectonic development of Big Horn Basin: Wyo. Geol. Assoc. Guidebook 2 .

- 1952, Big Horn Basin tectonics: Wyo. Geol. Assoc. Guidebook 7, p. 19-21.

Fidlar, M. M., 1950, Structural features of the Green River Basin: Wyo. Geol. Assoc. Guidebook 5, p. 86-87.

Flint, R. F., 1924, A brief review of Rocky Mountain structure: Jour. Geology, v. 32, p. $420-425$.

Forrester, J. D., 1937, Structure of the Uinta Mountains: Geol. Soc. America Bull., v. 48, p, 631-666.

Frielinghausen, K. W., 1952, The Phosphoria formation of southern and southeastern Big Horn Basin, Big Horn, Hot Springs and Washakie Counties, Wyo. : Wyo. Geol. Assoc. Guidebook 7, p. 55-57.

Fryxell, F. M., 1933, Earthquake shocks in Jackson Hole, Wyo.: Seismol. Soc. America Bull., v. 23, p. 167-168.

1938, Postglacial faulting in the Teton Range, Wyo. [abs.] : Geol. Soc. America Bull., v. 49, pt. 2, no. 12, pt. 2, p. 1881.

1944, The geology of Jackson Hole: 11 p. Washington, D. C., Natl. Parks Assoc.

Gilbert, G. K., 1880, The Wasatch, a growing mountain [abs.] : Phil. Soc. Wash. Bull. 2, p. 195.

1928, Studies of Basin Range structure: U. S. Geol. Survey Prof. Paper 153, p. 57-59, 61-67.

Gilliland, W. N., 1952, Another Tertiary crustal disturbance in central Otah: Am. Assoc. Petroleum Geologists Bull., v. 36, no. 7, p. 1461-1464.

Gilluly, James, 1932, Geology and ore deposits of the Stockton and Fairfield quadrangles, Utah: U. S. Geol. Survey Prof. Paper 173, 171 p.

Gleason, C. D., 1931, Faults on the eastern flank of the Wind River Mountains, Wyo. [abs.] : Geol. Soc. America Bull., v. 42, p. 333.

Green, Jack, and Young, W. A. Jr., 1937, The Park City mining district [Utah] : Compass, v. 17, p. 159-162.

Gutenberg, Beno, and Buwalda, J. P., 1935, Seismic methods applied to the Brigham Basin [abs.] : Geol. Soc. America Proc. 1934, p. 79-80.

Hares, C. J., 1942, Casper Mountain fault, Wyo. [abs.] : Geol. Soc. America Bull., v. 53, no. 12, pt. 2, p. 1802-1803.

Hayden, F. V., 1878, Some remarks in regard to the period of elevation of those ranges of the Rocky Mountains near the source of the Missouri River and its tributaries: Am. Jour. Sci., v. 33, p. 305-313, 1862; U. S. Geol. Geog. Survey Terr. Prelim. Rept. 1878, p. 9-13. 
- Heaton, R. L., 1929, Relation of accumulation to structure in northwestern Colorado, in Structure of typical American oil fields, v. 2, p. 93-114: Am. Assoc. Petroleum Geologists.

1937, Stratigraphy versus structure in Rocky Mountain region: Am. Assoc. Petroleum Geologists Bull., v. 21, p. 1241-1267.

* 1950, Late Paleozoic and Mesozoic history of Colorado and adjacent areas: Am. Assoc. Petroleum Geologists Bull., v. 34, no. 8, p. 1659-1698. Maps, no scale given.

Hewett, D. F., 1920, The Heart Mountain overthrust, Wyo.: Jour. Geology, v. 28, p. 536-557; abs., Wash. Acad. Sci. Jour., v. 10, p. 51; Geol. Soc. America Bull., v: 31, p. 122.

* Hewett, D. F., and Lupton, C. T., 1917, Anticlines in the southern part of the Big Horn Basin, Wyo.: U. S. Geol Survey Bull. 656, p. 17-18; abs., Wash. Acad. Sci. Jour., v. 8, p. 204-205, 1918. Map, scale 1:500,000.

Horberg, Leland, 1938, The structural geology and physiography of the Teton Pass area, Wyo.: Augustana Libr, Pubs., no. 16, p. 1-86; review, Blackwelder, Eliot: Jour. Geomorphology, v. 2, no. 4, p. 376-378, 1939.

* Horberg, C. L., Nelson, V. E., and Church, H. V., 1940, Structural types and trends in central western Wyoming: Geol. Soc. America Bull., v. 60, p. 183-216, 1949 ; abs., v. 51, p. 1930. Map, scale 1 in. to about $12 \mathrm{mi}$.

Hughes, R. V., 1933, The geology of the Beartooth Mountain front in Park County, Wyo. : Natl. Acad. Sci. Proc., v. 19, no. 2, p. 239-253. Map, scale 1 in. to $4 \mathrm{mi}$.

Irwin, J. S., 1926, Faulting in the Rocky Mountain region : Am. Assoc. Petroleum Geologists Bull., v. 10, p. 105-129.

Johnson, B. L., 1945, The phosphate rock deposits and industry of the Western States [abs.] : Econ. Geology, v. 40. no. 1, p. 87-88.

Jones, C. C., 1914, The discovery and opening of a new phosphate field in the United States: Am. Inst. Min. Metall. Eng. Trans., v. 47, p. 192-216.

* Jones, Charles T., 1940, Subsurface section from Big Muddy field, Converse County, Wyo., through Nebraska to central Kansas uplift, Ellis County, Kans. : Kans. Geol. Soc. Guidebook 14, p. 140-141, 1 flg.

* Karlstrom, T. N. V., 1948, Geology and ore deposits of the Hecla mining district, Beaverhead County, Mont.: Mont. Bur. Mines and Geology Mem. 25, $87 \mathrm{p}$. Maps, scales 1 in. to $1000 \mathrm{ft}$, 1 in. to $1 / 2 \mathrm{mi}$.

Keefer, E. K., Love, J. D., and Larsen, R. M., 1949, Map of Wyoming, showing test wells for oil and gas, anticlinal axes, oil and gas flelds, pipelines, unit areas, and land district boundaries: U. S. Geol. Survey Oil and Gas Inv. Prelim. Map 107. Scale 1:500,000.

Keith, Arthur, 1928, Structural symmetry in North America: Geol. Soc. America Bull., v. 39, p. 321-385.

King, P. B., 1932, An outline of the structural geology of the United States: Internat. Geol. Congress, 16th sess, United States, 1933, Guidebook 28.

Kinney, D. M., 1951, Geology of the Uinta River and Brush Creek-Diamond Mountain areas, Duchesne and Uintah Counties, Utah: U. S. Geol. Survey Oil and Gas Inv. Map OM 123. Scale 1: 63,360.

Knight, S. H., 1944, The physical evolution of the Rocky Mountains of southern Wyoming: New York Acad. Sci. Trans., ser. 2, v. 7, no. 2, p. 37-38.

- Krampert, E. W., 1949, Commercial oil in Cambrian beds, Lost Soldier field, Carbon and Swèetwater Counties, Wyo.: Am. Assoc. Petroleum Geologists Bull., v. 33; p. 1998-2010.

* La Fleiche, Pierre, 1944, Geologic aspect of Wyoming and outlook for development [of oil and gas fields] : Oil and Gas Jour., v. 43, no. 13, p. 38, 41-42. 
Lammers, E. C. H., 1937, The structural geology of the Livingston Peak area, Mont. : Jour. Geology, v. 45, p. 268-295. Map, scale 1 in. to about 11/8 mi.

1939, Pre-Cambrian control of Laramide structures in the Beartooth Range, Montana and Wyoming [abs.]: Geol. Soc. America Bull., v. 50, no. 12, pt. 2, p. 1918, 1939 ; Pan-Am. Geologist, v. 73, p. 157-158.

Langenheim, R. L., Jr., 1952, Pennsylvanian and Permian stratigraphy in Crested Butte quadrangle, Gunnison County, Colo.: Am. Assoc. Petroleum Geologists Bull.; v. 36 , no. 4 , p. $543-574$.

Laurence, R. A., and Sheets, M. M., 1934, Geology of Logan Mountain, Wyo., and its bearing upon the Heart Mountain overthrust [abs.]: Geol. Soc. America Proc. 1933, p. 93-94.

Lawson, A: C., 1931, The isostasy of the Uinta Mountains: Jour. Geology, v. 39, p. 264-276.

Longwell, C. R., 1944, Tectonic map of the United States : Am. Assoc. Petroleum Geologists Bull., v. 28, p. 1767-1774. Șcale 1: 2,500,000.

Loughlin, G. F., 1913, Reconnaissance in the southern Wasatch Mountains, Utah : Jour. Geology, v. 21, p. 436-452 ; abs., Wash. Acad. Sci. Jour., v. 3, p. 50-51:

Love, J. D., 1937, Buried mountain range in northwestern Wyoming [abs.] : Geol. Soc. America Proc. 1936, p. 87-88.

1938, Age of structural features along the northwestern margin of the Wind River Basin, Wyo. [abs.] : Geol. Soc. America Proc. 1937, p. 97.

1940, Thrust faulting at the southern end of the Big Horn Mountains, Wyo. [abs.] : Geol. Soc. America Bull., v. 51, no. 12, pt. 2, p. 1934.

* Love, J. D., Keefer, W. R., and Duncan, D. C., 1951, Geologic map of the Spread Creek-Gros Ventre River area, Teton County, Wyo.; U. S. Geol. Survey Oil and Gas Inv. Map OM 118. Scale 1 in. to $4000 \mathrm{ft}$.

Ludlum, J. C., 1943, Structure and stratigraphy of part of the Bannock Range, Idaho: Geol. Soc. America Bull., v. 54, p. 978-986. Map, scale 1 in. to 3 mi.

Lupton, C. T., 1916, Notes on the stratigraphic and structural relations in southern and eastern Bighorn Basin, Wyo. [abs.] : Wash. Acad. Sci. Jour., v. 6, p. 310-311.

* Lupton, C. T., and Lee, W. T., 1921, Geology of the Cat Creek oil field, Fergus and Garfield Counties, Mont.: Am. Assoc. Petroleum Geologists Bull., v. 5, p. 259.

* McCabe, W. S., 1947, The Elk Basin field, Park County, Wyo., and Carbon. County, Mont. [abs.] : Am. Assoc. Petroleum Geologists-Soc. Econ., Geologists and Mineralogists-Soc. Econ. Geophysicists Joint Ann. Mtg., Los Angeles, Mar. 24-30, Program, p. 29.

* Mansfield, G. R., 1915, Geology of the Fort Hall Indian Reservation, Idaho [abs.] : Wash. Acad. Sci. Jour., v. 5, p. 492-493.

*—1916, Types of Rocky Mountains structure in southeastern Idaho: Jour. Geology, v. 29, p. 444-468, 1921; abs., Wash. Acad. Sci. Jour., v. 6, p. 565.

- 1920, Types of Rocky Mountain structure in southeastern Idaho [abs., with discussion by G. W. Stose] : Geol. Soc. America Bull., v. 31, p. 126-127. 1923, Structure of the Rocky Mountains in Idaho and Montana : Geol. Soc. America Bull., v. 34, p. 263-284.

1927, Structural features of southeastern Idaho [abs.] : Geol. Soc. America Bull., v. 38, p. 212, 1927 ; Pan-Am. Geologist, v. 47, no. 4, p. 320.

-1927, Summary of the geology of southeastern Idaho with notes on recent work [abs.] : Wash. Acad. Sci. Jour., v. 17, p. 129-130.

*__ 1927, Geography, geology and mineral resources of parts of southeastern Idaho: U. S. Geol. Survey Prof. Paper 152, pp. 1-409. Maps, various scales. 1929, Structure of the Blackfoot Mountains, Idaho [abs.] : Wash. Acad. Sci. Jour., v. 19, p. 292. 
Marsell, R. E., 1947, Basin Range faulting near Salt Lake City [abs.] : Utah Acad. Sci. Proc. 1945-46, v. 23, p. 15, 16.

Masters, J. A., 1952, The Frontier formation of Wyoming: Wyo. Geol. Assoc. Guidebook 7, p. 58-62.

Mathews, A. A. L., 1931, Thrust structure of the central Wasatch Mountains [abs.] : Geol. Soc. America Bull., v. 42, p. 230, 1931; Pan-Am. Geologist, v. 55, p. 315.

Maxey, G. B., 1946, Cambrian stratigraphy in the northern Wasatch region: Utah State Agr. Coll., Logan, unpub. thesis.

Miller, G. W., 1904, Geology of the Butte mining district, Montana: Ores and Metals, v. 13, no. 10, p. 15-16; no. 11, p. 19-20.

Nelson, V. E., 1942, The structural geology of the Cache Creek area, Gros Ventre mountains, Wyo.: Augustana Lib. Pub. 18, 46 p.

* Nelson, V. E., and Church, Victor, 1943, Critical structures of the Gros Ventre and northern Hoback Ranges, Wyo. : Jour. Geology, v. 51, p. 143-166. Maps, scale $1 \mathrm{in}$. to $4 \frac{1}{4} \mathrm{mi}$.

Newberry, J. S., 1881, Geological facts recently observed in Montana, Idaho, Utah, and Colorado: N. Y. Acad. Sci. Trans. 1, p. 4-8, 1881 ; Science, v. 2, p. 523-524.

Nolan, T. B., 1928, A late Paleozoic positive area in Nerada: Am. Jour. Sci., 5 th ser., จ. 16, p. 153-161.

1943, The Basin and Range province in Utah, Nevada, and California : U. S. Geol. Survey Prof. Paper 197-D, p. 141-196.

Pack, F. J., 1921, Geology of Weber County [Utah] : Utah Univ. Bull., v. 11, no. 19, p. 5-33.

1926, New discoveries relating to the Wasatch fault: Am Jour. Sci., 5th Ser., v. 11, p. 399-410.; abs., Geol. Soc. America Bull., v. 37, p. 182 ; PanAm. Geologist, $\nabla .45$, p. 170.

Pardee, J. T., 1947, Late Cenozoic faulting in western Montana [abs.] : Geol. Soc. America Bull, v. 58, no. 12, pt. 2, p. 1215.

1950, Late Cenozoic block faulting in western Montana : Geol. Soc. America Bull., v. 61, p. 359-406.

* Pickering, W. Y., and Dorn, C. L., 1948, Rangely oil field, Rio Blanco County, Colo., in Structure of typical American oil fields, v. 3, p. 132-152; Am. Assoc. Petroleum Geologists.

Pierce, W. G., 1941, Heart Mountain and South Fork thrusts, Park County, Wyo. : Am. Assoc. Petroleum Geologists Bull., v. 25, p. 2021-2045.

1948, Geologic and structure contour map of the Basin-Greybull area, Big Horn County, Wyo.: U. S. Geol. Survey Oil and Gas Inv. Prelim. Map, 77. Scale 1 in. to about $4 / 5 \mathrm{mi}$.

- Pierce, W. G., Andrews, D. A., and Keroher, J. K., 1947, Structure contour map of the Big Horn Basin, Wyo. and Mont.: U. S. Geol. Survey Oil and Gas Inv. Prelim. Map 74.

Ransome, F. L., 1915, The Tertiary orogeny of the North American Cordillera and its problems, in Problems of American Geology, p. 287-386 : New Haven, Yale University. Maps, various scales.

* Richards, R. W., and Mansfield, G. R., 1912, The Bannock overthrust; a major fault in southeastern Idaho and northeastern Utah: Jour. Geology, v. 20, p. $681-709$.

1913, Structural features of a portion of southeast Idaho [abs.] : Geol. Soc. America Bull. 24, p. 675.

* Richmond, G. M., 1945, Geology and oil possibilities at the northwest end of the Wind River Mountains, Sublette County, Wyo.: U. S. Geol. Survey Oil and Gas Inv. Prelim. Map 31. Scale 1 in. to $1 \mathrm{mi}$. 
* Rocky Mountain Association of Geologists, Intermountain Association of Petroleum Geologists, New Mexico Geological Society, and Wyoming Geological Association, 1951, Rocky Mountain region: Am. Assoc. Petroleum Geologists Bull., v. 35, no. 2, p. 274-315. Maps, various scales.

Ross, C. P., 1928, Salient features of geology of south-central Idaho [abs.]: Wash. Acad. Sci. Jour., v. 18, p. 267-268.

Rouse, J. T., 1940, Structural and volcanic problems in the southern Absaroka Mountains, Wyo.; Geol. Soc. America Bull., v. 51, p. 1413 1428.

* Schneider, Hyrum, 1925, A discussion of certain geologic features of the Wasatch Mountains: Jour. Geology, v. 33, p. 28-48.

*Schoff, S. L., 1951, Geology of the Cedar Hills, Utah : Geol. Soc. America Bull., v. 62 , p. 619-646. Map, scale 1 in. to $2 \mathrm{mi}$.

Schuchert, Charles. 1923, Sites and nature of the North American geosynclines: Geol. Soc. America Bull., v. 34, p. 184-87.

Sears, J. D., 1924, Geology and oil and gas prospects of part of Moffat County, Colo., and southern Sweetwater County, Wyo.: U. S. Geol. Survey Bull. 751, p. 269-319.

* Sielaff, R. L., 1940, Oil fields of the Ferris-Lost Soldier district, Carbon County, Wyo. : Kans. Geol. Soc. Guidebook 14, p. 161-162.

Skeels, D. C., 1939, Structural geology of the Trail Creek-Canyon Mountain area, Mont. : Jour. Geology, v. 47, no. 8, p. 816-840.

Sloss, L. L., 1950, Paleozoic sedimentation in Montana area: Am. Assoc. Petroleum Geologists Bull., v. 34, p. 423-451.

Spieker, E. M., 1938, Structure of the Uinta Mountains : Geol. Soc. America Bull. [discussion and reply], v. 48, Supp., p. 2037-2043.

- 1946, Late Mesozoic and early Cenozoic history of central Utah: U. S. Geol. Survey Prof. Paper 205 D, p. 117-161.

Stille, Hans W., 1940, Einführung in den Bau Amerikas, Band 20, 717 p., Berlin, Gebrüder Borntraeger.

Stillman, F. B., 1928, A reconnaissance of the Wasatch front between Alpine and American Fork canyons, Utah: Jour. Geology, v. 36, p. 44-55. Map, scale $1: 31,250$.

Stose, G. W., and Ljungstedt, O. A., 1932, Geologic map of the United States : U. S. Geol. Survey. Scale $1: 2,500,000$.

Swanson, R. W., 1938, Recent fault scarp in the Madison Range, Mont. [abs.] : Geol. Soc. America Bull., v. 49, no. 12, pt. 2, p. 1902.

Talmadge, J. E., 1901, Geology of Utah: Internat. Min. Cong., United States, Proc. p. 42-48.

Thom, W. T., Jr., 1923, The relation of deep-seated faults to surface structural features of central Montana: Am. Assoc. Petroleum Geologists Bull., v. 7, p. 1-13.

1938, Bighorn Basin-Yellowstone Valley structural field conference, 1937 : Am. Assoc. Petroleum Geologists Bull., v. 22, p. 306-308; discussion, v. 22, p. 308-309.

- 1943, Structural geology and oil possibilities of the Big Horn Basin, Wyo.: Oil Weekly, v. 111, no. 9, p. 26-28; abs., Inst. Petroleum Jour., v. 30, 58 A-59 A, 1944.

1952, Structural features of the Big Horn Basin: Wyo. Geol. Assoc. Guidebook 7, p. 15-18.

Thom, W. T., Jr., Wilson, C. W., Jr., and Mac Neil, D. J., 1934, Results of recent studies of certain critical structural type, space, and time relationships in Yellowstone-Beartooth-Big Horn region [abs., with discussion] : Geol. Soc. America Proc. 1933, p. 58-60. 
Thomas, C. R., and others, 1945, Structure contour maps of the Rangely anticline, Rio Blanco and Moffat Counties, Colo.: U. S. Geol. Survey Oil and Gas Inv. Prelim. Map 41. Scale 1 in. to $1 / 2 \mathrm{mi}$.

*Thomas, H. D., 1949, The geological history and geological structure of Wyoming: Wyo. Geol. Survey Bull. 42, p. 19-20; abs., Regional stratigraphy and structure of 'Wyoming, Oil and Gas Jour., v. 46, p. 113, 1948.

* Van Houten, F. B., 1950, Geology of the western part of the Beaver Divide area, Fremont County, Wyo.: U. S. Geol. Survey Oil and Gas Inv. Map OM 113. Scale $1: 31,680$.

Ver Wiebe, W. A., 1930, Ancestral Rocky Mountains : Am. Assoc. Petroleum Geologists Bull. 14, p. 765-788.

*ـ 1930, Oil fields in the United States, p. 447-558 : New York, McGraw-Hill Book Co.

1949, Oil fields in North America : 251 p., Wichita, Kans., Edwards Bros.

Vhay, J. S., 1940, Structural features on the north side of the Beartooth Mountains near Nye, Mont. [abs.] : Wash. Acad. Sci. Jour., v. 30, p. 490-491.

* Walker, C. L., and Sims, Frank, 1950, Geologic map and structure sections Cumberland Reservoir-Little Muddy Creek areas, Lincoln County, Wyo.: Wyo. Geol. Assoc. Guidebook 5. Scale 1 in. to $2 \mathrm{mi}$.

Weart, R. C., 1947, Geology of the northern flank of the Wind River Mountains, Wyo. ([abs.] : Geol. Soc. America Bull., v. 58, no. 12, pt. 2, p. 1238-1239.

Williams, J. Stewart, 1948, Geology of the Paleozoic rocks, Logan quadrangle, Utah : Geol. Soc. America Bull., v. 59, p. 1121-1164. Map; scale 1: 125,000.

* Williams, N. C., 1940, Summary of Wasatch Mountain geology : Compass, v. 20, p. 75-78.

*Wilson, C. W., Jr., 1934, Geology of the thrust fault near Gardiner, Mont. : Jour. Geology, v. 42, p. 649-663. Map, scale 1 in. to about $13 / 8 \mathrm{mi}$.

Woodbury, H. O., 1950, Snider Basin area, Sublette County, Wẏo.: Wyo. Geol. Assoc. Guidebook 5, p. 122.

\section{PHYSIOGRAPHY}

Alden, W. C., 1924, Physiographic development of the northern Great Plains: Geol. Soc. America Bull., v. 35, p. 385-424.

1925; Pre-Wisconsin glaciation of northern Rocky Mountains [abs.] : PanAm. Geologist, v. 43, p. 371-372.

1926, Glaciation and physiography of Wind River Mountains, Wyo. [abs.] : Wash. Acad. Sci. Jour., จ. 16, p. 73.

1926, The mountain that made a lake: Travel, v. 47, p. 20-21, 45, July.

1927, The Gros Ventre landslide of June, 1925 [abs.] : Wash. Acad. Sci.

Jour., v. 17, p. 123.

1928, Landslide and flood at Gros Ventre, Wyo.: Am. Inst. Min. Metall. Eng. Tech. Pub. 140, 14 p.; Trans. v. 76, p. 347-361; abs., Mining and Metallurgy, v. 9, p. 465 .

Andrews, D. A., Pierce, W. G., and Eargle, D. H., 1947, Geologic map of the Big Horn Basin, Wyo. and Mont., showing terrace deposits and physiographic features: U. S. Geol. Survey Oil and Gas. Inv. Prelim. Map 71. Scale 1 in. to $2 \mathrm{mi}$.

Atwood, W. W., 1907, The glaciation of the Uinta Mountains: Jour. Geology, v. 15, p. $790-804$.

1908, Lakes of the Uinta Mountains: Am. Geog. Soc. Bull., v. 40, p. 12-17.

*__ 1909, Glaciation of the Uinta and Wasatch Mountains: U. S. Geol. Sur-

vey Prof. Paper 61, p. 9-10, pl. 1.

- 1916, The physiographic conditions at Butte, Mont., and Bingham Canyon, Utah, when the copper ores in these districts were enriched: Econ. Geology, จ. 11, p. 697-740. 
Atwood, W. W., and Atwood, W. W., Jr., 1938, Working hypothesis for the physiographic history of the Rocky Mountain region: Geol. Soc. America Bull., v. 49 , p. 957-980.

1945, The physiographic history of an Eocene skyline moraine in western Montana : Jour. Geology, v. 53, p. 191-199.

Atwood, W. W., Jr., 1935, Erosional history of the Wind River Range, Wyo. [abs.] : Assoc. Am. Geographers Annals, v. 25, no. 1, p. 33-34.

- Bacon, C. S., Jr., 1948, Geology of the Confusion Range, west-central Utah: Geol. Soc. America Bull., v. 59, p. 1027-1052.

Bailey, R. W., 1927, The Bear River Range fault, Utah : Am. Jour. Sci., 5th ser., จ. 13, p. 497-502.

Baker, C. L., 1938, Physiographic development of Wind River Mountains, Wyo. [abs.] : Geol. Soc. America Bull., v. 49, no. 12, pt. 2, p. 1864-1865.

Baker, V. R., 1942, A brief review of the physiography and structure of the Teton Range, Wyo.: Compass, v. 22, no. 3, p. 207-211.

* Bauer, C. M., 1932, The geology of the southeastern part of the Wind River Basin, Wyo. [abs.] : Colo. Univ. Studies, v. 20, no. 1 (Colo. Univ. Bull., v. 32, no. 15), p. 6-7.

-1940, Geology along the southern margin of the Absaroka Range, Wyo. [discussion] : Jour. Geology, v. 48, p. 324-327.

Bevan, A. C., 1921, Some geologic features of the Beartooth Mountains, Mont. [abs.] : Geol. Soc. America Bull., v. 32, p. 29.

*_ 1923, Summary of the geology of the Beartooth Mountains, Mont.: Jour. Geology, v. 31, p. 441-465. Map, scale 1 in. to $20 \mathrm{mi}$. 1925, Rocky Mountain peneplains northeast of Yellowstone Park: Jour. Geology, v. 33, p. 563-587. 1927, Glaciation of the Beartooth Mountains, Mont. [abs.] : Geol. Soc. America Bull., v. 38, p. 143 ; Pan-Am. Geologist, v. 47, p. 150-151.

1928, Rocky Mountain Front in Montana [abs.] : Geol. Soc. America Bull., v. 39, p. 160-161, 1928; Pan-Am. Geologist, v. 49, p. 71-72.

1931, Glaciation northeast of Yellowstone National Park [abs.] : Geol. Soc. America Bull., v. 42, p. 325.

1941, Beartooth icefield [abs.] : Geol. Soc. America Bull., v. 52, no. 12, pt. 2, p. 1889-1890.

1944, Rainbow ice cap, Beartooth Mountains, Mont. [abs.] : Geol. Soc. America Bull., v. 55, p. 1463-1464.

1945, Glacial drift on East Boulder Plateau, Beartooth Mountains, Montana [abs.] : Geol. Soc. America Bull., v. 56, no. 12, pt. 2, p. 1147.

Blackwelder, Eliot, 1912, The Gros Ventre slide, an active earth flow: Geol. Soc. America Bull., v. 23, p. 487-492 ; abs., v. 23, p. 739.

1915, Post-Cretaceous history of the mountains of central western Wyoming: Jour. Geology, v. 23, p. 97-117, 193-217, 307-340.

1925, Wasatch Mountains revisited [abs.] : Geol. Soc. America Bull., v. 36, p. 132-133, 1925 ; Pan-Am. Geologist, v. 43, p. 74-75.

1950, Pleistocene geology, the Green River Basin, Wyo.: Wyo. Geol. Assoc. Guidebook 5, p. 81-85.

Booneville, Capt. B. L. E., 1837, Journal of Capt. B. L. E. Booneville, See under Irving, Washington.

* Boutwell, J. M., and others, 1933, The Salt Lake region : Internat. Geol. Cong., 16th sess., United States, 1933, Guidebook 17, Excursion C-1, 149 p., Maps, various scales.

Bradley, F. H., 1873, Explorations of 1872 : U. S. Geol. Survey of the Territories, under Dr. F. V. Hayden; Snake River Region: Am. Jour. Sci., 3d Ser. v. 6, p. 194-207. 
Bradley, W. H., 1932, Erosion surfaces on the north flank of the Uinta Mountains [abs.] : Wash. Acad. Sci. Jour., v. 22, p. 318.

1936, Geomorphology of the north flank of the Uinta Mountains: U. S. Geol. Survey Prof. Paper 185-I, p. 163-199.

* Branson, E. B., and Branson, C. C., 1940, Geology of Wind River Mountains, Wyo.: Am. Assoc. Petroleum Geologists Bull. 25, p. 120-151, 1941. Map, scale 1 in. to about $7 \mathrm{mi}$. ; abs., Oil and Gas Jour., v. 38, no. 48, p. 55, 1940.

* 1945, Glaciation in the southern part of the Wind River Mountains and their foothills [abs.] : Geol. Soc. America Bull., v. 56, no. 12, pt. 2, p. 1148-1149.

Buss, W. R., 1949, Physiography [Utah], in The oil and gas possibilities of Utah, p. 5-9: Utah Geol. Mineralog. Survey.

Church, Victor, 1941, Structural geology of the central portion of the Gros Ventre Range, Wyo. [abs.] : Utah Acad. Sci. Proc., v. 18, p. 17.

Dake, C. L., 1919, Glacial features on the south side of Beartooth Plateau, Wyo.: Jour. Geology, v. 27, p. 128-131.

Dana, E. S., and Grinnell, G. B., 1876, Geological report; in Ludlow, William, Report of reconnaisance . . . to the Yellowstone National Park, p. 89-126: Washington. Also in U. S. (War Dept.) Chief Engineer Ann. Rept. 1876; U. S. 44th Cong. 2d sess., H. Ex. Doc. 1, pt. 2, v. 2, pt. 3, App. N. N., p. 657-694.

Davis, W. M., 1903, The mountain ranges of the Great Basin: Harvard Coll. Mus. Comp. Zoology Bull., v. 42, Geol. Ser. v. 6, no. 3, p. 129-177.

1905, The Wasatch, Canyon, and House Ranges, Utah: Harvard Coll. Mus. Comp. Zoology Bull., v. 49, Geol. Ser., v. 8, no. 2, p. 17-28.

1920, Features of glacial origin in Montana and Idaho: Assoc. Am. Geographers Annals, v. 10, p. 75-147.

Delo, D. M., 1940, Recent recession of Dinwoody glaciers, Wind River Mountains, Wyo. [abs.] : Geol. Soc. America Bull., v. 51, no. 12, pt. 2, p. 1924.

Dennis, P. E., 1944, Shore lines of the Escalante Bay of Lake Bonneville, Utah: Utah Acad. Sci. Proc., v. 19-20, 1941-43, p. 121-124; abs., p. 27.

Dutton, C. E., 1880, Report of the geology of the High Plateaus of Utah : U. S. Geol. Geog. Survey Rocky Mtn. Region, v. 32, p. 178.

Eardley, A. J., 1933, Strong relief before block faulting in the vicinity of the Wasatch Mountains, Utah: Jour. Geology, v. 41, p. 243-267; abs., Geol. Soc. America Bull., v. 43, p. 135-136, 1932 ; Pan-Am. Geologist, v. 57, p. 65, 1932. 1934, Structure and physiography of the southern Wasatch Mountains, Utah: Mich. Acad. Sci. Papers, v. 19, p. 377-400; abs., Geol. Soc. America Bull., v. 44, p. 83-84.

1941, Structure and physiography of the north-central Wasatch Mountains, Utah: Utah Acad. Sci. Proc., v. 19-20, 1941-43, p. 19, (1944?) ; abs., Geol. Soc. America Bull., v. 52, no. 12, pt. 2, p. 1899.

- 1_ 1944, Geology of the north-central Wasatch Mountains, Utah: Geol. Soc. America Bull., v. 55, p. 819-894; abs., Utah Acad. Sci. Proc., v. 19-20, p. 19. Maps, scales $1 \mathrm{in}$. to $2 \mathrm{mi}$., $1 \mathrm{in}$. to $1 \mathrm{mi}$.

Edmund, R. W., 1938, Pleistocene glaciation of the west slope of the Teton Mountains, Wyo. : Iowa Univ. Unpub. M. thesis, 150 p. Maps, various scales.

- 1940, Structural geology and physiography of the northern end of the Teton Mountains, Wyo.: Iowa Univ. unpub. dissertation, 163 p. ; abs., Iowa Univ. Pub., Aims and Prog. Research Ser., No. 66. Map, scale 1 in. to $2 \mathrm{mi}$.

Emmons, S. F., 1887, Notes on the geology of Butte, Mont. : Am. Inst. Min. Eng. Trans., v. 16, p. 49-62.

Fenneman, N. M., 1931, Physiography of wèstern United States : 534 p., New York, McGraw-Hill Book Co., Inc. 
*Field, R. M., and others, 1932, Yellowstone-Beartooth-Big Horn region : Internat. Geol. Cong., 16th sess., United States, 1933, Guidebook 24, Excursion C-2, $64 \mathrm{p}$. Maps, various scales.

Frémont, J. O., 1845, Narrative of the exploring expedition to the Rocky Mountains in the year 1842, and to Oregon and California in the years 1843-44: Cong. Doc., 28th Congr., 2d sess., Sen. Doc. 174, House Doc. 166, p. 130-132. Subsequent eds.

Fryxell, F. M., 1930, Glacial features of Jackson Hole, Wyo.: Augustana Libr. Pabs., no. 13, 129 p.

1934, The Teton peaks: Mountaineering Jour., v. 2, p. 150-156, London. 1938, Postglacial faulting in the Teton Range, Wyo. [abs.]: Geol. Soc. America Bull., v. 49, no. 12, pt. 2, p..1881.

*__ 1938, The Tetons, interpretations of a mountain landscape : Univ. Calif. Press, $73 \mathrm{p}$.

-1941, 1941 mud flows in the Teton Range, Wyo. [abs.] : Geol. Soc. America Bull., v. 52, no. 12, pt: 2, p. 1902-1903.

- 1944, The geology of Jackson Hole: Washington, D. C., Nat. Parks Assoc., $11 \mathrm{p}$.

Fryxell, F. M., and Horberg, Leland, 1942, Structural surfaces on the west slope of the Teton Range, Wyo. [abs.] : Geol. Soc. America Bull., v. 53, no. 12, pt. 2, p. 1801-1802.

1943, Alpine mud flows in Grand Teton National Park, Wyo.: Geol. Soc. America Bull., v. 54, p. 457-472.

Fryxell, F. M., Horberg, Leland, and Edmund, Rudolph, 1941, Geomorphology of the Teton Range and adjacent basins, Wyo.-Idaho [abs.] : Geol. Soc. America Bull., v. 52, no. 12, pt. 2, p. 1903.

Gilbert, G. K., 1880, The Wasatch, a growing mountain [abs.] : Philos. Soc. Wash. Bull. 2, p. 195.

1890, Lake Bonneville: U. S. Geol. Survey Mon. 1, 438 p.

1928, Studies of Basin Range structure: U. S. Geol. Survey Prof. Paper 153, p. 57-59, 61-67.

Granger, Walter, 1910, Tertiary faunal horizons in the Wind River Basin, Wyo., with descriptions of new Eocene mammals: Am. Mus. Nat. Hist. Bull., v. 28, p. 235-251.

Hague, Arnold, 1888, Geological history of the Yellowstone National Park: Am. Inst. Min. Eng. Trans. 16, p. 783-803; Smithsonian Inst. Ann. Rept. 1892, p. 133-151, 1893; abs., Pop. Sci. Monthly, v. 36, p. 282-283, 1889.

Hayden, F. V., 1876, Notes descriptive of some geological sections of the country about the headwaters of the Missouri and Yellowstone Rivers: U. S. Geol. and Geog. Surv. Terr. Bull. 2, p. 197-209.

* Hintze, F. F., 1913, A contribution to the geology of the Wasatch Mountains, Utah: New York Acad. Sci. Annals, v. 23, p. 85-142.

Horberg, Leland, 1938, The structural geology and physiography of the Teton Pass area, Wyo.: Augustana. Libr. Pubs., no. 16, p. 1-86; rev. by Blackwelder, Eliot, Jour. Geomorphology, v. 2, no. 4, p. 376-378, 1939.

1940, Geomorphic problems and glacial geology of the Yellowstone Valley, Park County, Mont.: Jour. Geology, v. 48, p. 275-303.

*Howard, A. D., 1937, History of the Grand Canyon of the Yellowstone: Geol. Soc. America Spec. Paper 6, 159 p.

Hughes, R. V., 1933, The geology of the Beartooth Mountain front.in Park County, Wyo.: Natl. Acad. Sci. Proc., v. 19, no. 2, p. 239-253. .Map, scale 1 in. to 4 mi. 
Irving, Washington, 1837, A map of the sources of the Colorado and Big Salt Lake, Platte, Yellowstone, Muscle-Shell, Missouri, and Salmon and Snake Rivers, branches of the Columbia River, in The Rocky Mountains; or Scenes, Incidents, and Adventures in the Far West, from the Journal of Capt. B. L. E. Booneville, v. 1, Philadelphia.

Jepson, G. L., 1930, Stratigraphy and paleontology of the Paleocene of northeastern Park County, Wyo.: Am. Philos. Soc. Proc., v. 69, no. 7, p. 463-528.

Johnson, D. W., Howard, A. D., and Mackin, J. H., 1934, Geomorphic researches in the Yellowstone Park and Big Horn Basins, Wyo. [abs.]: Science, new ser., v. 79, no. 2055 , p. 461-462.

Johnson, D. W., and Mackin, J. H., 1934, Geomorphic studies in the Big Horn Basin, Wyo. [abs.] : Geol. Soc. America Proc. 1933, p. 55-56.

Johnson, D. W., Mackin, J. H., and Howard, A. D., 1934, Geomorphic studies in the Rocky Mountain region of Wyoming [abs.]: Assoc. Am. Geographers Annals, v. 24, no. 1, p. 57-58.

Knight, S. H., 1942, The physical evolution of the Rocky Mountains [abs.] : Tulsa Geol. Socc. Digest, v. 10, 1941-42, p. 36.

1944, The physical evolution of the Rocky Mountains of southern Wyoming: New York Acad. Sci. Trans., ser. 2, v. 7, no. 2, p. 37-38.

1950, Physical aspects of the Green River Basin and adjacent mountain ranges: Wyo. Geol. A.ssoc. Guidebook 5, p. 75-80.

Lee, W. T., 1924, Geography, geology, and physiography of the Great Salt Lake Basin: U. S. Geol. Survey Water-Supply Paper 517, p. 3-9.

Leggette, R. M., and Taylor, G. H., 1937, Geology and ground-water resources of Ogden Valley, Utah: U. S. Geol. Survey Water-Supply Paper 796, p. 107-110.

Lindgren, Waldemar, 1918, The Idaho peneplain [discussion]: Econ. Geology, v. 13, p. $486-488$.

Livingston, D. C., 1918, The Idaho peneplain [discussion] : Econ. Geology, v. 13, p. 488-492.

Love, J. D., 1934, Tertiary history of the southern end of the Absaroka Range, Wyo. [abs.] : Colo.-Wyo. Acad. Sci. Jour., v. 1, no. 6, p. 31-32.

- 1941, Geology along the southern margin of the Absaroka Range [reply] : Joui. Geology, v. 49, p. 101-106.

Ludlum, J. C., 1943, Structure and stratigraphy of part of the Bannock Range, Idaho : Geol. Soc. America Bull., v. 54, p. 978-986. Map, scale 1 in. to 3 mi.

Mackin, J. H., 1937, Erosional history of the Big Horn Basin, Wyo.: Geol. Soc. America Bull., v. 48, p. 813-893.

- Mansfield, G. R., 1915, Geology of the Fort Hall Indian Reservation, Idaho [abs.] : Wash. Acad. Sci. Jour., v. 5, p. 492-493.

1921, Geography of southeastern Idaho: Assoc. Am. Geographers Annals, v. 15, p. 51-64, 1925 ; abs., v. 11, p. 128-129.

1924, Tertiary planation in Idaho: Jour. Geology, v. 32, p. 472-487; abs., Assoc. Am. Geographers Annals, v. 14, no. 1, p. 43.

- 1925, Physiography of southeastern Idaho [abs.] : Wash. Acad. Sci. Jour., v. 15, p. 182-183.

- 1927, Geography, geology, and mineral resources of part of southeastern Idaho: U. S. Geol. Survey Pror. Paper 152, p. 1-409. Maps, various scales. 1937, Blackfoot Valley, a typical valley system in southeastern Idaho

[abs.] : Geol. Soc. America Proc. 1936, p. 402.

1937, Erosional history of the Paradise Valley quadrangle, Idaho [abs.] :

Wash. Acad. Sci. Jour., v. 27, p. 358.

Matthes, F. E., 1900, Glacial sculpture of the Big Horn Mountains, Wyo.: U. S. Geol. Survey Ann. Rept. 21, pt. 2, p. 167-190; abs., Science, new ser., v. 11, p. 507. 
Miner, N. A., and Apfel, E. T., 1946, Three stages of glaciation identifled in Wind River Valley, Wyoming [abs.] : Geol. Soc. America Bull., v. 57, no. 12, pt. 2, p. 1218-1219.

Moody, C. L., and Taliaferro, N. L., 1918, Anticlines near Sunshine, Park County, Wyo. : Calif. Univ. Dept. Geol. Bull. 10, p. 445-459. Map, scale 1 in. to about $11 / 3$ miles.

Palmer, J. T., 1931, Outline of the geology of Idaho: Geog. Soc. Philadephia Bull., v. 29, no. 4, p. 55-61 (299-305).

Pardee, J. T., 1947, Late Cenozoic block faulting in western Montana: Geol. Soc. America Bull., v. 61, p. 359-406 ; abs., v. 58, p. 1215, 1947.

Parsons, W. H., 1939, Glacial geology of the Sunlight area, Park County, Wyo.: Jour. Geology, v. 47, p. 737-747, 1939, abs., Geol. Soc. America Proc. 1937, p. 102-103.

Perry, E. S., 1934, Physiography and ground water supply in the Big Horn Basin, Mont: Mont. Bur. Mines and Geology Mem. 12. Map, scale 1 in to $8 \mathrm{mi}$.

Resser, C. E., 1929, Cambrian geology of the Rocky. Mountains: Smithsonian Inst. Explor. and Fieldwork 1928, p. 21-26, 1929.

1930, Further studies of Cambrian geology in the Rocky Mountains: Smithsonian Inst. Explor. and Fieldwork 1929, p. 23-30.

Rich, J. L., 1918, An old erosion surface in Idaho-is it Eocene: Econ. Geology, v. 13, p. 120-126.

1918, Dating of peneplains; an old erosion surface in Idaho, Montana, and Washington-is it Eocene [abs., with discussion by B. L. Clark and Eliot Blackwelder] : Geol. Soc. America Bull., v. 29, p. 89-90.

Richmond, G. M., 1941, Multiple glaciation of the Wind River Mountains, Wyo. [abs.] : Geol. Soc. America Bull., v. 52, no. 12, pt. 2, p. 1929-1930.

1948, Modification of Blackwelder's sequence of Pleistocene glaciation in the Wind River Mountains, Wyo. [abs.] : Geol. Soc. America Bull., v. 59, p. 1400-1401.

1949, Stone nets, stone stripes, and soil stripes in the Wind River Mountains, Wyo.: Jour. Geology, v. 57, p. 143-153 ; abs., Colo.-Wyo. Acad. Sci. Jour., v. 3, p. 28, 1948.

Ross, C. P., 1928, Salient features of geology of south-central Idaho [abs.] : Wash. Acad. Sci. Jour., v. 18, p. 267-268.

1929, Early Pleistocene glaciation in Idaho : U. S. Geol. Survey Prof. Paper 158, p. 123-128; abs., Wash. Acad. Sci. Jour.; v. 19, p. 50. Map, scale 1 inch to 2 miles.

1930, Erosion surfaces in Idaho [with discussion by G. R. Mansfield and

A. L. Anderson] : Jour. Geology, v. 38, p. 643-561.

1931, The physiography of south-central Idaho [abs.] : Wash. Acad. Sci. Jour., v. 21; p. 369.

1935, Geomorphology of south-central Idaho [abs.] : Geol. Soc. America Proc. 1934, p. 103.

Rouse, J. T., 1934, The physiography and glacial geology of the Valley region, Park County, Wyo. : Jour. Geology, v. 42, p. 738-752.

- Schneider, Hyrum, 1919, General geology of-Utah : Utah Univ. Bull., v. 10, no. 11 [Eng. Sta., Dept. Metall. Research Bull. 12] p. 3-33, 89-91.

- Schoff, S. L., 1951, Geology of the Cedar Hills, Utah : Geol. Soc. America Bull., v. 62, p. 619-646. Map, scale 1 in. to $2 \mathrm{mi}$.

Scott, H. W., 1938, Eocene glaciation in southwestern Montana : Jour. Geology, จ. 46, p. $628-636$. 
Sears, J. D., 1924, Relations of the Browns Park formation and the Bishop conglomerate and their role in the origin of the Green and Yampa rivers: Geol. Soc. America Bull., v. 35, p. 279-304; abs., Geol. Soc. America Bull., v. 35, no. 1 , p. 93 ; Pan-Am. Geologist, v. 41, p. 146 . Maps, no scales given.

Sharp, H. S., 1938, The upland of the Beartooth Mountains, Mont. [abs.] : Geol. Soc. America Proc. 1937, p. 113.

Sinclair, W. J., 1912, Some glacial deposits east of Cody, Wyo. and their relation to the Pleistocene erosional history of the Rocky Mountain region [abs.] : Geol. Soc. America Bull., v. 23, p. 731.

Spieker, E. M., and Billings, M. P.,. 1940, Glaciation in the Wasatch Plateau, Utah : Geol. Soc. America Bull., v. 51, p. 1173-1197; abs., Geol. Soc. America Proc. 1937, p. 115, 1938.

St. John, O. H., 1883, Report on the geology of the Wind River district: U. S. Geol. Geog. Survey Terr. Ann. Rept. 12, p. 173-270.

*Swenson, F. A., 1942, Geology of the northwest flank of the Gros Ventre Mountains, Wyo.: Iowa Univ. unpub. dissert., 100 p. ; abs., Iowa Univ. Pub., Aims and Prog. Research ser. no. 71, 1 p., unnumbered. Map, scale 1 in. to $13 / / \mathrm{mi}$.

Talmadge, J. E., 1901, Geology of Utah : Internat. Min. Cong. 4th, Proc., p. 42-48.

* Tansley, Wilfred, Schafer, P. A., and Hart, L. H., 1933, A geological reconnaissance of the Tobacco Root Mountains, Madison County, Mont. : Mont. Bur. Mines and Geology Mem. 9, 57 p. Map, scale 1 in. to $21 / 2 \mathrm{mi}$.

Thom, W. T., Jr., Jones, O. T., and Chamberlin, R. T., 1935, Morphology of the Beartooth Mountain uplift [abs.] : Geol. Soc. America Proc. 1934, p. 117.

Umpleby, J. B., 1912, An old erosion surface in Idaho; its age and value as a datum plane: Jour. Geology, v. 20, p. 139-147 ; abs., Wash. Acad. Sci. Jour., v. 2, p. 109-110.

- 1913, The old erosion surface of Idaho [reply] : Jour. Geology, v. 21, p. 224-231.

Vhay, J. S., 1940, Structural features on the north side of the Beartooth Mountains near Nye, Mont. [abs.] : Wash. Acad. Sci. Jour., v. 30, 490-491.

Weed, W. H., 1893, The glaciation of the Yellowstone Valley north of the Park: U. S. Geol. Survey Bull. 104, 41 p.

1906, Shifting of the Continental Divide at Butte, Montana [abs.] : Geol. Soc. America Bull. 16, p. 587.

Wentworth, C. K., and Delo, D. M., 1931, Dinwoody glaciers, Wind River Mountains, Wyo.; with a brief survey of existing glaciers in the United States: Geol. Soc. America Bull., V. 42, p. 605-620; abs., v. 47, no. 1, p. 240-241 ; PanAm. Geologist, v. 55, p. 308.

Westgate, L. G., and Branson, E. B., 1913, The later Cenozoic history of the Wind River Mountains, Wyo.: Jour. Geology, v. 21, p. 142-159.

White, C. A., 1889, On the geology and physiography of a portion of northwestern Colorado and adjacent parts of Utah and Wyoming: U. S. Geol. Survey Ann. Rept. 9, p. 677-712. Map, scale 1:812,500.

* Williams, N. C., 1940, Summary of Wasatch Mountain geology : Compass, v. 20, p: $75-78$.

Wilson, L. R., 1941, An esker-like deposit on the Middle Teton Glacier [abs.] : Iowa Acad. Sci. Proc., v. 47, p. 272.

*Wyoming University, Wyoming Geological Association, and Yellowstone-Bighorn Research Association, 1947, Guidebook, Field conference in the Big. horn Basin, Aug. 5-8, 277 p.

Young, J, Lu, 1939, Glaciation in the Logan quadrangle. Utah [abs.] : Utah Acad. Sci. Proc., v. 16, p. 21-22. 


\section{FAUNA AND FIORA OF THE PHOSPHORIA FORMATION} AND ITS PARTIAL STRATIGRAPHIC EQUIVALENTS IN THE WESTERN FIELD

* Anderson, A. L., 1931, Geology and mineral resources of eastern Cassia County, Idaho: Idaho Bur. Mines and Geology Bull. 14, p. 35-37, 96, 101-102, 17 pls. Map, scale $1: 25,000$.

* Atwood, W. W., 1909, Glaciation of the Uinta and Wasatch Mountains: U. S. Geol. Survey Prof. Paper 61, p. 9-10, pl. 1.

* Bacon, C. S., Jr., 1948, Geology of the Confusion Range, west-central Utah: Geol. Soc. America Bull., v. 59, p. 1027-1052.

* Baker, A. A., 1946, Geology of the Green River Desert-Cataract Canyon Region, Emery, Wayne, and Garfield Counties, Utah: U. S. Geol. Survey Bull. 951, p. 32-50.

*__ 1947, Stratigraphy of the Wasatch Mountains in the vicinity of Provo, Utah : U. S. Geol. Survey Oil and Gas Inv. Prelim. Chart 30.

* Biss, N. W., and Northrup, S. A., 1950, South Canyon Creek dolomite member, a unit of Phosphoria age in Maroon formation near Glenwood Springs, Colo. : Am. Assoc. Petroleum Geologists Bull., v. 34, no. 7, p. 1540-1551.

* Blackwelder, Eliot, 1913, New or little known Paleozoic faunas from Wyoming and Idaho: Am. Jour. Sci., 4th ser., v. 36, p. 174-149.

* Boutwell, J. M., 1912, Geology and ore deposits of the Park City district, Utah: U. S. Geol. Survey Prof. Paper 77, p. 42, 49-52 ; abs., Wash. Acad. Sci. Jour., v. 3 , p. 445-447. Map, scale $1: 25,000$.

*Branson, C. C., 1930, Paleontology and stratigraphy of the Phosphoria formation: Mo. Univ. Studies, ๆ. 5, no. 2, p. 1-99; abs., Chicago Univ. Abs. Theses, Sci. Ser., v. 7, p. 211-217, 1931.

*_ 1932, Discovery of conodonts in the Phosphoria Permian of Wyoming: Science, new ser., v. 75, p. 337-338.

- 1932, Sharks with grasping teeth from the Permian [abs.] : Geol. Soc. America Bull., v. 43, p. 283-284, 1933 ; Pan-Am. Geologist, v. 57, no. 2, p. 159-160.

* _ 1933, Fish fauna of the middle Phosphoria formation: Jour Geology, v. 41, p. 174-183.

* 1934, Permian sharks of Wyoming and of East Greenland : Science, new ser., v. 79, p. 431.

*__ 1936, Carboniferous stratigraphy of Wyoming [abs.] : Geol. Soc. America Proc. 1935, p. 391-392.

*_ 1938, Permian Foraminifera in Wyoming [abs.]: Geol. Soc. America Proc. 1937, p. 270.

1939, Pennsylvanian formations of central Wyoming: Geol. Soc. America Bull., v. 50, p. 1199-1225.

1948, Bibliographic index of Permian invertebrates: Geol. Soc. America Mem. 26, $1049 \mathrm{p}$.

*Branson; E. B., 1916, The lower Embar of Wyoming and its fauna: Jour. Geology, v. 24, p. 639-664.

Branson, E. B., and Mehl, M. G., 1932, Footprint records from the Paleozoic and Mesozoic of Missouri, Kansas and Wyoming: Geol. Soc. America Bull., v. 43, p. 383-398; abs., no. 1, p. 284-285; Pan-Am. Geologist, v. 57, no. 2, p. 160. 1938, Use of conodonts in correlating strata of the Rocky Mountains [abs.] : Geol. Soc. America Proc. 1937, p. 306-307.

* Butler, B. S., and others, 1920, The ore deposits of Utah: U: S. Geol. Survey Prof. Paper 111, p. 295, 642, pl. 57. Maps, large and small.scales. $296348-54-5$ 
Calkins, F. C., and Emmons, W. H., 1915, Description of the Philipsburg, Mont., quadrangle: U. S. Geol. Survey Geol. Atlas, folio 196, p. 8, 25, columnar section. Map, scale $1: 125,000$.

* Condit, D. D., 1916, Relations of the Ember and Chugwater formations in central Wyoming: U. S. Geol. Survey Prof. Paper 98, p. 263-270; abs., Wash. Acad. Sci. Jour., v. 7, p. 162 [1917].

1924, Phosphate deposits in the Wind River Mountains, near Lander, Wyo.: U. S. Geol. Survey Bull. 764, 39 p.; map, scale $1: 125,000$.

* Darton, N. H., 1906, Geology of the Owl Creek Mountains: Cong. Doc., 59th Cong., 1st Sess., S. Doc. 219, p. 17-18, 31-32. Map, scale 1 in. to $4 \mathrm{mi}$.

- Darton, N. H., Blackwelder, Eliot, and Siebenthal, C. E., 1910, Description of the Laramie and Sherman quardrangles, Wyo.: U. S. Geol. Survey Geol. Atlas, Folio 173, 17 p. Map, scale 1: 125,000.

Darton, N. H., and Siebenthal, C. E., 1909, Geology and mineral resources of the Laramie Basin, Wyo.: U. S. Geol. Survey Bull. 364, 81 p. Map, scale 1 in. to $11 / 2 \mathrm{mi}$.

* DeFord, R. K., 1941, Permian problems [abs.] : Tulsa Geol. Soc. Digest, v. 9, p. 38-41.

* Dunbar, C. O., 1941, Permian faunas; a study in facies: Geol. Soc. America Bull., v. 52, p. 313-332.

* Fisher, C. A., 1906, Geology and water resources of the Bighorn Basin, Wyo.: U. S. Geol. Survey Prof. Paper 53, p. 17-18. Map, scale 1 in. to $4 \mathrm{mi}$.

* Foster, H. L., 1947, Paleozoic and Mesozoic stratigraphy of northern Gros Ventre Mountains and Mount Leidy Highlands, Teton County, Wyo.: Am. Assoc. Petroleum Geologists Bull., v. 31, p. 1537-1593. Abs., Geol. Soc. America Bull., v. 57, no. 12, pt. 2, p. 1194, 1946.

* Frenzel, H., and Mundorff, M. J., 1942, Fusulinidae from the Phosphoria formation of Montana: Jour. Paleontology, v. 16, p. 675-684, 1942; abs., Oil and Gas Jour., v. 39, no. 47, p. 65, 1941.

* Gilluly, James, 1929, Geology and oil and gas prospects of part of the San Rafael Swell, Utah: U. S. Geol. Survey Bull. 806, p. 82.

Girty, G. H., 1903, The Carboniferous formations and faunas of Colorado: U. S. Geol. Survey Prof. Paper 16, 546 p.

1908, On some new and old species of Carboniferous fossils: U. S. Natl. Mus. Proc. 34, p. 281-303.

- 1910, The fauna of the phosphate beds of the Park City formation in Idaho, Wyoming, and Utah: U. S. Geol. Survey Bull, 436, $82 \mathrm{p}$.

1920, Carboniferous and Triassic faunas: U. S. Geol Survey Prof. Paper111, p. 641-657, pls. 52-57.

* Hague, Arnold, Iddings, J. P., Weed, W. H., and others, 1899, Geology of the Yellowstone National Park: U. S. Geol. Survey Mon. 32, pt. 2, Descriptive geology, petrography, and paleontology, 893 p. Maps, various scales.

* Hintze, F. F., 1013; A contribution to the geology of the Wasatch Mountains, Utah: New York Acad. Sci. Annals, v. 23, p. 85-142.

Hyatt, Alpheus, and Smith, J. P., 1905, The Triassic cephalopod genera of America: U. S. Geol. Survey Prof. Paper 40, 394 p.

- Jones, C. C., 1913, The discovery and opening of a new phosphate field in the United States: Am. Inst. Min. Eng. Bull. 82, p. 2411-2435; Trans. v. 47, p. 192-216, 1914.

- King, R. E., 1931, The geology of the Glass Mountains, Texas, Pt. II, Faunal summary and correlation of the Permian formations with description of Brachiopoda : Texas Univ. Bull 3042, p. 10-35. 
* Love, J. D., 1934, The geology of the western end of the Owl Creek Mountains, Wyo.: Wyo. Geol. Survey Bull. 24, 25 p. Map, scale 1 in. to about $2 / 3 \mathrm{mi}$.

* 1939, Geology along the southern margin of the Absaroka Range, Wyo. Geol. Soc. America Special Paper 20, p. 11-12, 31-38, pls. 8 and 17. Map, scale 1 in. to about $11 / 4 \mathrm{mi}$.

- McKelvey, V. E., 1946, Preliminary report on stratigraphy of the phosphatic shale member of the Phosphoria formation in western Wyoming, southeastern Idaho, and northern Utah: U. S. Geol. Survey open-file report, $162 \mathrm{p}$.

* Mansfield, G. R., 1920, Geography, geology, and mineral resources of the Fort Hall Indian Reservation, Idaho, with a chapter on water resources by W. B. Heroy : U. S. Geol. Survey Bull. 713, 152 p. Map, scale 1: 125,000.

* 1927, Geography, geology, and mineral resources of part of south. eastern. Idaho: U. S. Geol. Survey Prof. Paper 152, 409 p. Maps, various scales.

1929, Geography, geology, and mineral resources of the Portneuf quadrangle, Idaho: U. S. Geol. Survey Bull. 803,110 p. Map, scale 1 in. to $1 \mathrm{mi}$.

* Miller, A. K., and Cline, L. M., 1934, Cephalopods of the Phosphoria formation of northwestern United States: Jour. Paleontology, v. 8, p. 281-302, 1 pl.; abs., Geol. Soc. America Proc. 1933, p. 365.

Miller, A. K., and Furnish, W. M., 1940, Permian ammonoids of the Quadalupe Mountains region and adjacent areas: Geol. Soc. America Spec. Paper 26, p. $9,23,28$.

- Miller, A. K., and Thomas, H. D., 1936, The Casper formation (Pennsylvanian) of Wyoming and its cephalopod fauna: Jour. Paleontology, v. 10, p. 715-738.

Miller, A. K., and Unklesbay, A. G., 1942, Permian nautiloids from western United States: Jour. Paleontology, v. 16, p. 719-738.

1943, The siphuncle of late Paleozoic ammonoids: Jour. Paleontology, v. 17, p. 1-25.

Miller, A. K., and Warren, P. S., 1933, A Propinacoceras from North America : Am. Jour. Sci., 5th ser., v. 26, p. 295-299.

Miller, A. K., and Youngquist, Walter, 1949, American Permian nautiloids : Geol. Soc. America Mem. 41, p. 9-10.

Newell, N. D., and Kummel, B. J., 1940, Permo-Triassic boundary in southeastern Idaho and western Wyoming [abs.]: Oil and Gas Jour., v. 38, no. 48, p. 66.

*__ 1941, Permo-Triassic boundary in Idaho, Montana, and Wyoming: Am. Jour. Sci., v. 239, p. 204-208.

Peale, A. C., 1893, The Paleozoic section in the vicinity of Three Forks, Mont.: U. S. Geol. Survey Bull. 110, p. 32-43. Map, scale 1: 250,000.

- Richards, R. W., and Mansfield, G. R., 1912, The Bannock overthrust; a major fault in southeastern Idaho and northeastern Utah: Jour. Geology, v. 20, p. 681-709.

Richardson, G. B., 1913, The Paleozoic section in northern Utah: Am. Jour. Sci., 4th ser., v. 36, no. 214, p. 406-416.

* 1941, Geology and mineral resources of the Randolph quadrangle, OtahWyo.: U. S. Geol. Survey Bull. 923, 54 p.

*Schuchert, Charles, 1933, Correlation of more important marine Permian sequences: Geol. Soc. America Bull., v. 46, no. 1, p. 1-46; abs., Pan-Am. Geologist, v. 60, p. 240, 1933 ; Internat. Geol. Cong., United States, 1933 Rept., v. 1, p. 701, 1936.

Smith, J. P., 1901, The border line between Paleozoic and Mesozoic in western America : Jour. Geology, v. 9, p. 512-521.

- 1904, The comparative stratigraphy of the marine Trias of western America : Calif. Acad. Sci. Proc., 3d ser., v. 1, p. 323-430. 
Spencer, A. C., 1917, The geology and ore deposits of Ely, Nev. : U. S. Geol. Survey Prof. Paper 96, p. 28.

*Telfer, L., 1934, Phosphate in the Canadian Rockies : Canadian Inst. Mining and Metallurgy Trans., v. 36, p. 566-605; Bull. 260, 1933.

*Thomas, H. D., 1934, A Phosphoria faunule from the "Embar" red beds [abs.] : Colo.-Wyo. Acad. Sci. Jour., v. 1, no. 6, p. 34.

* _ 1934, Phosphoria and Dinwoody tongues in lower Chugwater of central and southeastern Wyoming: Am. Assoc. Petroleum Geologists Bull., v. 18, p. 1655-1697.

1935, The brachiopod Punctospirifer pulchra (Meek) : Am. Midland Naturalist, v. 16, no. 2, p. 203-207.

_ـ 1937, Plicatoderbya, a new Permian brachiopod subgenus : Jour. Paleon: tology, v. 11, p. 13-18.

'Thompson, M. L., and Scott, H. W., 1941, Fusulinids from the type section of the Aower Pennsylvanian Quadrant formation [Wyo.] : Jour Paleontology, v. 15, no. 4, p. 349-353.

*Thompson, M. L., Wheeler, H. E., and Hazzard, J. C., 1946, Permian fusulinids of California : Geol. Soc. America Mem. 17, p. 2, 8.

Warren, P. S., 1927, Banff Area, Alberta : Canada Geol. Survey Mem. 153, 94 p., [no. 2121].

Weeks, F. B., and Ferrier, W. F., 1907, Phosphate deposits in western United States : U. S. Geol. Survey Bull. 315, p. 449-462; abs., Science, new ser., v. 25, p. $620-621$.

*Westoll, T. S., 1941, The age of certain Permian fish-bearing strata : Geol. Mag., v. 78, p. $37-44$.

*White, [G.] David, 1923, Permian of western America from the paleobotanical standpoint: Pan-Pacific Sci. Cong., Australia, 1923, p. 1050-1077.

*Williams, J. Stewart, 1939, "Park City" beds on southwest flank of Uinta Mountains, Utah : Am. Assoc. Petroleum Geologists Bull., v. 23, p. 82-100.

*Woodruff, E. G., 1911, The Lander oil field, Fremont County, Wyo. : U. S. Geol. Survey Bull. 452, p. 10-14. Map, scale $1: 63,360$.

*Youngquist, W., Hawley, R. W., and Miller, A. K., 1951, Phosphoria conodonts from southeastern Idaho: Jour. Paleontology, v. 25, no. 3, p. 356-364.

\section{MINERALOGY AND CHEMICAL COMPOSITION OF THE PHOSPHORIA AND PARK CITY FORMATIONS}

*Adams, F. D., and Dick, W. J., 1915, Discovery of phosphate of lime in the Rocky Mountains : Canada Comm. Conserv., $36 \mathrm{p}$.

*__ 1917, Discovery of phosphate of lime in the Rocky Mountains [with discussion oy W. F. Ferrier and L. D. Burling] : Canadian Min. Inst. Trans., จ. 19 , p. $321-348$.

Alexander, L. T., and Jacob, K. D., 1930, Mechanical analysis of finely divided natural phosphates: U. S. Dept. Agriculture Tech. Pub. Bull, 212, 24 pp.

Axelrod, J. M., 1946, A field test for vanadium: U. S. Geol. Survey Bull. 950, p. 19-23.

*Bell, R. N., Moore, F. C., Campbell, S., 1905-1921, Annual reports of the mining industry of Idaho.

Blackwelder, Eliot, 1916, The geologic role of phosphorus: Am. Jour. Sci., ser. 4, v. 42, p. $285-298$.

* Bowen, C. F., 1918, Phosphatic oil shales near Dell and Dillon, Beaverhead County, N10nt.! U. S. Geol. Survey Bull. 661, p. 315-320. 
${ }^{*}$ Calkins, F. D., and Butler, B. S., 1943, Geology and ore deposits of the Cottonwood-American Fork area, Utah, with sections on history and production by V. C. Heikes: U. S. Geol. Survey Prof. Paper 201, p. 2, 30-31, 89. Map, scale $1: 250,000$.

Chatard, T. M., 1893, Phosphate chemistry as it concerns the miner : Am. Inst. Mining Trans., v. 21, p. 160-175.

Clarke, F. W., 1924, The data of geochemistry : U. S. Geol. Survey Bull. 770, 5th ed., p. 523-534.

*Condit, D. D., 1919, Oil shale in western Montana, southeastern Idaho, and adjacent parts of Wyoming and Utah: U. S. Geol. Survey Bull. 711-B, p. 15-40, 1920 ; abs., Wash. Acad. Sci. Jour., v. 9, p. 638.

*__ 1924, Phosphate deposits in the Wind River Mountains, near Lander, Wyo.: U. S. Geol. Survey Bull. 764, 39 p. Map, scale $1: 125,000$.

*Condit, D. D., Finch, E. H., and Pardee, J. T., 1928, Phosphate rock in the Three Forks-Yellowstone Park region, Montana : U. S. Geol. Survey Bull. 795, p. 147-209.

Curtis, Harry A. 1938, Western phosphate deposits : Indus. Eng. Chemistry Jour., v. 30, p. $973-979$.

*Deiss, Charles, 1949, Phosphate deposits of the Deer Creek-Wells Canyon area, Caribou County, Idaho: U. S. Geol. Survey Bull. 955-C, 99. p.

*De Schmid, H. S., 1916, Investigation of a reported discovery of phosphate in Alberta : Canada Mines Br. Bull. 12, 38 p.

- 1917, A reconnaissance for phosphate in the Rocky Mountains; and for graphite near Cranbrook, B. C.: Canada Mines Br. Summary Rept. 1916, p. $22-35$.

Fairchild, J. G., 1912, The accurate volumetric determination of phosphoric acid in phosphate rock: Indus. Eng. Chemistry Jour., v. 4, p. 520-522.

*Gale, H. S., and Richards, R. W., 1910, Preliminary report on the phosphate deposits in southeastern Idaho and adjacent parts of Wyoming and Utah: U. S. Geol. Survey Bull. 430, p. 457-535. Maps, scale 1: 62,500.

*Gardner, L. S., 1944, Phosphate deposits of the Teton Basin area, Idaho-Wyo.: U. S. Geol. Survey Bull. 944-A, 36 p. Maps, scale 1: 48,000.

Hendricks, S. B., Hill, W. L., and Jacob, K. D., 1931, Structural characteristics of apatite-like substances and composition of phosphate rock and bone as determined from X-ray diffraction examinations: Indus. Eng. Chemistry, v. 23, p. 1413-1418.

Hill, W. L., and Jacob, K. D., 1933 Determination and occurrence of iodine in phosphate rock: Jour. Assoc. Off. Agr. Chemists, v. 16, p. 135.

Hill, W. L., Marshall, H. L., and Jacob, K. D., 1932, Composition of crude phosphoric acid prepared by sulfuric acid process: Indus. Eng. Chemistry, v. 24, p. 1064-1068.

1932, Minor metallic constituents of phosphate rock: Indus. Eng. Chemistry, v. 24, p. 1306-1312.

1933 , Occurrence of sulphur, organic matter, nitrogen, and water in phosphate rock: Jour. Assoc. Off. Agr. Chemists, v. 16, p. 260-276.

Jacob, K. D., Hill, W. I., and Marshall, H. L., 1933, The composition and distribution of phosphate rock with special reference to the United States: U. S. Dept. Agriculture Tech. Bull. 364, 90 p.

Jacob, K. D., Rader, L. F., Jr., and Ross, W. H., 1932, Comparison of two percent citric acid and ammonium citrate solutions, as solvents for phosphates : Jour. Assoc. Off. Agr. Chemists, v. 15, p. 146-162.

Jacob, K. D., and Reynolds, D. S., 1928, The fluorine content of phosphate rock: Jour. Assoc. Off. Agr. Chemists, v. 11, p. 242-250. 
Jacob, K. D., Reynolds, D. S., and Marshall, H. L., 1936, Phosphate fertilizer by calcination process-volatilization of fluorine from phosphate rock at high temperatures: Am. Inst. Min. Metall. Eng. Tech. Pub. 695, 14 p.

*Jones, C. C., 1907, Phosphate rock in Utah, Idaho, and Wyoming: Eng. Min. Jour., v. 83, p. 953-955.

Kazakov, A. V., 1937, [Chemical nature of the phosphate substance of phosphorites and their genesis-I. The system $\mathrm{CaO} \cdot \mathrm{P}_{2} \mathrm{O}_{5} \cdot \mathrm{H}_{2} \mathrm{O}$ in the field of low concentration] : Nauch. inst. po ydobreniyam i insectofungisidam im. Ya. V. Samoylova, Trudy, vypusk 139, 13 p. [Russian].

*Keller, W. D., 1939, Petrography and origin of the Rex Chert: Geol. Soc. America Bull., v. 52, p. 1279-1298, 1941; abs., v. 50, p. 1915-1916.

*King, R. H., 1947, Phosphate deposits near Lander, Wyo.: Wyo. Geol. Survey Bull. 39, 84 p., 6 pls. Maps, scales 1 in. to $500 \mathrm{ft}$., 1 in. to $2 \mathrm{mi}$.

Knight, S. H., 1932, Origin of the crinkly structure of the Forelle limestone [abs.] : Colo.-Wyo. Acad. Sci. Jour., v. 1, no. 4, p. 32.

Lundel, G. E. F., and Hoffman, J., 1924, The analysis of phosphate rock: Jour. Assoc. Off. Agr. Chemists, v. 8, p. 184-206.

Maas, A. R., 1945, Phosphate philosophy: Chem. Metall. Eng., v. 52, no. 12. p. 112-114.

*McConnell, Duncan, 1950, The petrography of rock phosphates: Jour. Geology, v. 58, no. 1, p. 16-22.

* McKelvey, V. E., 1946, Preliminary report on stratigraphy of the phosphatic shale member of the Phosphoria formation in western Wyoming, southeastern Idaho, and northern Utah: U. S. Geol. Survey open-file report, $162 \mathrm{p}$.

*___ 1949, Geological studies of the western phosphate field, in Symposium on western phosphate mining; Min. Eng., v. 1, p. 270-279.

* Mansfield, G. R., 1915, Geology of the Fort Hall Indian Reservation, Idaho [abs.] : Wash. Acad. Sci. Jour., v. 5, p. 492-493.

- 1927, Geography, geology, and mineral resources of part of southeastern Idaho; U. S. Geol. Survey Prof. Paper 152, 409 p. Maps, various scales. 1928, Phosphate of the United States, in Opik, A., Les réserves mondiales en phosphates, p. 719-776: Madrid, Bur. 14 ${ }^{\circ}$ Congrés Géologique International, Espagne, 1926.

1920, Geography, geology, and mineral resources of the Portneuf quadrangle, Idaho: United States Geol. Survey Bull. 803, 110 p. Map, scale $1 \mathrm{in.}$ to $1 \mathrm{mi}$.

*_ 1931, Some problems of the Rocky Mountain phosphate field: Econ. Geology, . . 26, p. 3533-374.

-___ 1937, Role of physical chemistry in stratigraphic problems : Econ. Geology, v. 32, p. 533-549.

1940, The role of fluorine in phosphate deposition: Am. Jour. Sci., v. 238, p. $863-879$.

Marshall, H. L., Jacob, K. D., and Reynolds, D. S., 1932, Occurrence of fluorine in natural phosphates; further studies : Indus. Eng. Chemistry, v. 24, p. 86-89.

*Newton, Joseph, 1944?, Phosphates: Idaho Bur. Mines and Geology Inf. Leaflet 13.

Newton, Joseph, and Finkelnburg, O. C., 1947, Beneflciation of Idaho phosphate rock : Idaho Bur. Mines and Geology, Min. Res. Rept. 3, 22, p.

Oakes, M. C., 1938, A field test for phosphates: Econ. Geology, v. 33, p. 454-457.

*Pardee, J. T., 1917, The Garrison and Philipsburg phosphate fields, Mont.; U. S. Geol. Survey Bull. 640, p. 195-228. Map, scale 1: 125,000.

1921, Phosphate rock near Maxville, Granite County, Mont.: U. S. Geol. Survey Bull. 715, p. 141-145. Map, scale $1: 125,000$. 
* Pardee, J. T., 1936, Phosphate rock near Maxville, Philipsburg, and Avon, Mont.: U. S. Geol. Survey Bull. 847, p. 175-188. Maps, scale 1 in. to $1 \mathrm{mi}$.

Feterson, William, 1914, Phosphate deposits in the Mississippian rocks of northern Utah : Science, new ser., v. 40, p. 755-756.

Phillips, W. B., 1893, A list of minerals containing at least one percent of phosphoric acid : Am. Inst. Min. Eng. Trans., v. 21, p. 188-196.

Pike, R. D., 1930, Volatilization of phosphorus from phosphate rock.-I, Experiments in crucibles and rotary kiln: Indus. Eng. Chemistry, v. 22, p. 242-245.

1930, Volatilization of phosphorus from phosphate rock.-II, Experiments in volatilization of phosphorus and potash in a blast furnace: Indus. Eng. Chemistry v. 22, p. 344-349.

- 1930, Volatilization of phosphorus from phosphate rock.-III, Calculations of performance of a blast furnace for volatilization of phosphorus and potash : Indus. Eng. Chemistry, v. 22, p. 349-354.

Prater, L. S., 1948, Reaction rates in the acidulation of Idaho phosphate rock with sulphuric acid: Idaho Bur. Mines and Geology Pamph. 79, 8 p.

Reynolds, D. S., Jacob, K. D., and Hill, W. L., 1929, Ratio of fluorine to phosphoric acid in phosphate rock : Indus. Eng. Chemistry, v. 21, p. 1253-1256.

Reynolds, D. S., and others, 1936, Phosphate fertilizers by calcination process: Indus. Eng. Chemistry, v. 28, p. 678-682.

* Richards, R. W., and Mansfield, G. R., 1911, Preliminary report on a portion of the Idaho phosphate reserve: U. S. Geol. Survey Bull. 470, p. 371-439. Maps, scales 1 in. to $1 \mathrm{mi} ., 1$ in. to $71 / 2 \mathrm{mi}$.

- 1914, Geology of the phosphate deposits northeast of Georgetown, Idaho : U. S. Geol. Survey Bull. 577, 76 p. Maps, scales 1 in. to $1 \mathrm{mi}$., 1 in. to $4 \mathrm{mi}$.

* Richards, R. W., and Pardee, J. T., 1925, The Melrose phosphate field, Montana : U. S. Geol. Survey Bull. 780, p. 1-32. Map, scale 1:62,500.

* Richardson, G. B., 1941, Geology and mineral resources of the Randolph quadrangle, Utah-Wyo. : U. S. Geol. Survey Bull. 923, 55 p. Map, scale 1: 125,000.

Richmond, W. E., Jr., 1940, Crystal chemistry of the phosphates, arsenates, and vanadates of the type $\mathrm{A}_{2} \mathrm{XO}_{4}(\mathrm{Z})$; Am. Mineralogist, v. 25, p. 441-479.

Rubey, W. W., 1933, [Abstract of an informal communication] : Wash. Acad. Sci. Jour., v. 23, p. 402.

- Sahinen, U. M., 1937, Phosphate rock in Montana, in Glück Auf. v. 2, no. 3, p. 10-11, Butte, Mont.

Sauchelli, Vincent, 1942, Manual on phosphates: Baltimore, Md. The Davidson Chemical Corp.

* Schereschewsky, Ph., 1947, Les mines de phosphate des Montagnes Rocheuses: Ann. Mines Mém., an 136, no. 1, p. 69-83.

* Schneider, Hyrum, 1919, General geology of Utah : Utah Univ. Bull., v. 10, no. 11 (Engin. Sta., Dept. Metall. Res. Bull. 12) p. 3-33, 89-91.

* Schultz, A. R., 1918, A geologic reconnaissance for phosphate and coal in southeastern Idaho, and western Wyoming: U. S. Geol. Survey Bull. 680, 84 p. Maps, various scales.

*__ 1918, A geologic reconnaissance of the Uinta Mountains, northern Utah, with special reference to phosphate: U. S. Geol. Survey Bull. 690, p. 31-94. Maps, scales 1 in. to $7 \mathrm{mi} ., 1$ in. to $24 \mathrm{mi}$.

Sellards, E. H., 1914, The origin, mining, and preparation of phosphate rock : Am. Inst. Min. Eng. Bull. 93, p. 2379-2395 ; Trans. v. 50, p. 901-916.

* Telfer, L., 1933, Phosphate in the Canadian Rockies: Canadian Inst. Mining and Metallurgy Trans., v. 36, p. 566-605, 1934 ; Bull. 260, p. 566-605.

United States Geological Survey 1906-1927, Mineral resources of the United States. 
Van Horn, F. B., 1911, Phosphate and potash deposits: Am. Fertilizer, v. 35, p. $68-70$, July.

Waggaman, W. H., 1914, The manufacture of acid phosphate: U. S. Dept. Agriculture Bull. 144, $28 \mathrm{p}$.

Waggaman, W. H. (assisted by Henry W. Easterwood), 1927, Phosphoric acid, phosphates, and phosphate fertilizers: p. 76-80, New York, The Chemical Catalog Co., Inc.,

Waggaman, W. H., and Fry, W. H., 1915, Phosphate rock and methods proposed for its utilization as a fertilizer: U. S. Dept. Agriculture Bull. 312, 37 p.

Wagner, C. R., and Ross, W. H., 1917, A modified method for the determination of fluorine with special application to the analysis of phosphates: Indus. Eng. Chemistry Jour., v. 9, p. 1116-1123.

Warren, P. S., 1927, Banff area, Alberta: Canada Geol. Survey Mem. 153, 94 p. [no. 2121].

*Williams, J. Steele, 1942, Ecological studies of late Paleozoic faunas : Natl. Research Council, Div. Geology and Geography Ann. Rept. App. N, p. 41-42.

* Winchester, D. E., 1923, Oil shale of the Rocky Mountain region: U. S. Geol. Survey Bull. 729, p. 20, 76-79, 82-87, 90-91, 127-129.

\section{MINERALOGY AND CHEMICAL COMPOSITION OF PHOSPHORITES}

Beevers, C. A., and MacIntyre, D. B., 1946, The atomic structure of fluor-apatite and its relation to that of tooth and bone material: Mineralog. Mag., no. 194, v. 27, p. 254-257.

Britske, E. V., Hummelfarb, B. M., and Kazakov, A. V., 1937, Geological investigations of agricultural ores USSR : Transactions of the Sci. Inst. of Fertilizers and Insecto-fungicides, no. 142, Moscow. [In English.] Published for the XVII Session of the International Geological Congress.

Burri, C., Jacob, J., and Parker, R., 1935, Uber hydroxylapatit von der Kemeleten bei Hospental: Schweizer, mineralog, petrog. Mitt., Band 16, Heft 2, p. 327-339.

Dadson, A. S., 1933, A study of some Canadian apatites: Toronto Univ. Studies Geol. ser. 35, p. 51-59.

Dallemagne, M. J., Brasseur, H., and Melon J., 1949, La constitution de la substance minérale de l'os et la synthèse des apatites: Soc. chim. France Bull. 1949, fasc. 3-4, mars-avril, p. 138-145.

Dana, James D., 1951, The system of mineralogy of James Dwight Dana and Edward Salisbury Dana, 7th ed. entirely rewritten and greatly enlarged by Charles Palache. Harry Berman. and Clifford Frondel: New Yopk, John Wiley and Sons, Inc. ; and London, Chapman and Hall, Ltd.

Deans, T., 1938, Francolite from sedimentary ironstones of the Coal Measures: Mineralog. Mag. v. 25, p. 135-139.

DeVilliers, J. W., 1942, The carbonate-apatites; francolite from Richtersveld, South Africa: Am. Jour. Sci. v. 240, p. 443-447.

Dihn, P., and Klement, R., 1942, Isomorphe apatitarten: Zeitschr. Elektrochemie, Band 48, p. 334-336.

Eisenberger, Sidney : Lehrman, Alexander, and Turner, W. D., 1940, The basic calcium phosphates and related systems-some theoretical and practical aspects. Chem. Rev. v. 26, no. 2, p. 257-296.

Frondel, Clifford, 1943, Mineralogy of the calcium phosphates in insular phosphate rock: Am. Mineralogist, v. 28, no. 4, p. 215-232.

Geiger, Th., 1950, Beiträge zum Problem der Karbonapatite : Schweizer mineralog. petrog. Mitt., Band 30, p. 161-181. 
Goldschmidt, V. M., and Thomassen, L., 1924, Röntgenspectrographische Untersuchungen iiber die Verteilung der seltenen Erdmetalle in Mineralen: $\mathbf{K}$. Norske vidensk. selsk., I. Mat. naturv. Ml. 1924, no. 5 [German].

Gruner, J. W., and McConnell, Duncan, 1937, The problem of the carbonate apatites: Zeitschr. f. Kristallographie, Band A 97, p. 208-215.

Hébert, Claude, 1947, Contribution à l'étude de la chimie des phosphates de calcium: Annales des mines, Mém. tome 136, no. 4, p. 5-93, Paris.

Hendricks, S. B., 1944, Polymer chemistry of silicates, borates, and phosphates: Wash. Acad. Sci. Jour. v. 34, 241-257.

Hendricks, S. B., and Hill, W. L., 1942, The inorganic constitution of bone: Science, 96 , p. 255-257.

- 1950, The nature of bone aıd phosphate rock: Natl. Acad. Sci. Proc., v. 36 , no. 12 , p. 731-737.

Hintze, C. A. F., 1924, Apatite: Handbuch der Mineralogie, Band 1, Lief. 22, p. 487-572, Berlin and Leipzig, Walter de Gruyter \& Co.

Hutchinson, G. E., 1950, The biogeochemistry of vertebrate excretion : Am. Mus. Nat. History Bull., v. 96, p. 554.

Hutton, C. O., and Seelye, F. T., 1942, Francolite, a carbonate-apatite from Milburn, Otago: Roy. Soc. New Zealand Trans., v. 72, p. 191-198.

Jacob, K. D., Hill, W. L., and Marshall, H. L., 1933, The composition and distribution of phosphate rock with special reference to the United States: U. S. Dept. Agriculture Tech. Bull. 364, 90 p.

Jaffe, E. B., 1951, Abstracts of the literature on synthesis of apatites and some related phosphates: U. S. Geol. Survey Circ. 135,78 p.

Kohler, A., and Haberlandt, H., 1934, Luminescenzanalyse von Apatit, Pyromorphit und einiger anderen Phosphaten: Chemie der Erde, Band 9, p. 88-89.

McConnell, Duncan, 1950, The petrography of rock phosphates: Jour. Geology, จ. 58 , no. 1 , p. 16-23.

1940, The problem of the carbonate-apatites, a carbonate oxyapatite: Am. Jour. Sci., v. 214, p. 135-139.

- 1938, A structural investigation of isomorphism of the apatite group: Am. Mineralologist v. 23, No. 1, p. 1-19; no. 3, p. 173-174; no. 9, p. 606.

McConnell, Duncan, and Gruner, J. W., 1940, Carbonate-apatite from Magnet Cove, Ark. : Am. Mineralogist v. 25, p. 157-167.

Mehmel, Martin, 1931, Beziehungen swischen Kristallstructure und chemische formel des apatites: Zeitschr. physikal. Chemie Abt. B. Band 15, Heft 32, p. 223-241.

Mitchell, Lane, Faust, G. T., Hendricks, S. B., and Reynolds, D. S., 1943, The mineralogy and genesis of hydroxylapatite: Am. Mineralogist, v. 28, no. 6, p. 356-371.

Naray-Szabo, St., 1930, The structure of apatite: Zeitschr. Kristallographie, Band 75 , p. $387-398$.

Oertel, A. C., and Stace, H. T. C., 1947, A spectrochemical survey of some phosphate rock and superphosphates: Australian Council Sci. Indus. Research Jour. v. 20, p. 110-113.

Palache, Charles; Berman, Harry, and Frondel, Clifford, 1951, The system of mineralogy of the Danas, v. 2, 7th ed., New York, John Wiley and Sons, Inc., and London, Chapman and Hall, Ltd.

Robinson, W. O., 1918, The presence and determination of molybdenum and rare earths in phosphate rock: Soil Sci., v. 66, no. 4, p. 31.7-322.

Sahama, T., and Vahatalo, V., 1949, X-ray spectographic study of the rare earths in some Finnish rocks and minerals: Comm. geol. Finlande Bull., no. 125.

Sandell, E. B., Hey, M. H., McConnell, Duncan, 1939, The composition of francolite: Mineralog. Mag., v. 25, p. 395-401. 
Silverman, S. R., Fuyat, R. K., and Weiser, J. D., 1951, The quantitative determination of calcite associated with carbonate-bearing apatites: U. S. Geol. Survey Trace Elements Inv. Rept. 118.

Strunz, H., and Schroeter, J., 1939, Plan einer Klassification der naturlichen Phosphate, Arsenate, and Vanadate: Zeitschr. Kristallographie, Band 102, Heft 1, p. 71-78.

Winchell, A. N., and Winchell, Horace, 1951, Elements of optical mineralogyPt. 2. 4th ed., 459 p., New York, John Wiley \& Sons, Inc.

Winther, Chr., with Böggild, O. B., 1901, On some minerals from the nephelite syenite at Julianehaab, Greenland (epistolite, britholite, schizolite, and steenstrupite) : Meddel. om Grønland, Bind 24, p. 181-213, (p. 790, rare-earth apatites).

Zambonini, Ferrucio, 1923, Uber die Mischkristalle, welche die Verbindungen des Calciums, Strontiums, Bariums, und Bleis mit jenen der seltenen Erden bilden : Zeitschr. Kristallographie, Band 58, p. 226-292.

\section{ORIGIN OF THE PHOSPHORIA FORMATION AND ITS MINERAL DEPOSITS}

* Adams, F. D., and Dick, W. J., 1915, Discovery of phosphate of lime in the Rocky Mountains : Canada Comm. Conserv., $36 \mathrm{p}$.

Blackwelder, Eliot, 1914, Origin of the Rocky Mountain phosphate deposits [abs.] : Min. Sci. Press, v. 109, p. 987; Geol. Soc. America Bull., v. 26, p. 100-101, 1915.

- 1916, The geologic role of phosphorous: Am. Jour. Sci., ser. 4, v. 42, p. 285-298; Natl. Acad. Sci. Proc. 2, p. 490-495.

- 1916, Geological transformations of phosphorous [abs.]: Geol. Soc. America Bull., v. 27, p. 47.

* Branson, C. C., 1932, Origin of phosphate in the Phosphoria formation [abs.] : Pan-Am. Geologist, v. 57, p. 160 ; Geol. Soc. America Bull., v. 43, p. 284, 1933.

Breger, C. L., 1911, Origin of Lander oil and western phosphate: Min. Eng. World, v. 35, p. 631-633.

* Clarke, F. W., 1924, The data of geochemistry : U. S. Geol. Survey Bull. 770, 5th ed: p. 523-534.

Clarke, F. W., and Wheeler, W. C., 1922, The inorganic constituents of marine invertebrates: U. S. Geol. Survey Prof. Paper 124, p. 61.

* Davidson, W. B. M., 1893, Notes on the geological origin of phosphate of lime in the United States and Canada: Am. Inst. Min. Eng. Trans., v. 21, p. 139-157.

* Gale, H. S., and Richards, R. W., 1910, Preliminary report on the phosphate deposits in southeastern Idaho and adjacent parts of Wyoming and Utah: U. S. Geol. Survey Bull. 430, p. 457-535. Maps, scale 1 : 62,500.

- Grabau, A. W., 1010, Prevailing stratigraphic relationshins of the bedded phosphate deposits on Europe, North Africa, and North America [abs.]: Geol. Soc. America Bull., v. 30, p. 104.

* Graham, W. A. P., 1925, Experiments on the origin of phosphate deposits : Econ. Geology, v. 20, p. 319-334.

Goldman, M. I., 1922, Basal glauconite and phosphate beds : Science, new ser., $\nabla$. 56, p. 171-173.

Green, J. R., 1943, Some steps in the formation of western phosphate rock: Mineralogist, v. 11, no. 6, p. 173-176, 186, 188.

- Hanson, A. M., 1942, Phosphate deposits in western Summit, Wasatch, Salt Lake, Morgan, and Weber Counties, Utah: Utah State Agr. Coll., Logan, unpub. thesis. 
* Jacob, K. D., Hill, W. L., and Marshall, H. L., 1933, The composition and distribution of phosphate rock with special reference to the United States: U. S. Dept. Agriculture Tech. Bull. 364, 90 p.

*Johnson, B. L., 1930, Phosphate rock : U. S. Bur. Mines Inf. Circ. 6256, 64 p.; abs., Phosphate rock, locations of deposits and mining methods employed: Pit and Quarry, v. 20, p. 44-46.

Kazahov, A. V., 1937, [Chemical nature of the phosphate substance of phosphorites and their genesis-I. The system $\mathrm{CaO} \cdot \mathrm{P}_{2} \mathrm{O}_{5} \cdot \mathrm{H}_{2} \mathrm{O}$ in the field of low concentration]: Nauch. inst. po ydobreniyam i insectofungisidam im. Ya. V. Samoylova, Trudy, vypusk 139, 73 p. [Russian].

1938, [The phosphorite facies and the genesis of natural phosphates]: Sovetskara geologia, tome 8 , no. 6, p. 33-47 [Russian].

*Keller, W. D., 1939, Petrography and origin of the Rex chert: Geol. Soc. America Bull., v. 52, p. 1279-1298, 1941 : abs., v. 50, p. 1915-1916.

* Kirkham, V. R. D., 1925, Phosphate deposits of Idaho and their relation to the world supply: Am. Inst. Min. Metall. Eng. Trans. [prepr.] 1405, 28 p., 1925 ; with discussion, Trans., v. 71, p. 308-338; repr., Idaho Bur. Mines and Geology ; abs., Mining and Metallurgy, v. 6, no. 221, p. 247-248.

- McKelvey, V. E., 1946, Preliminary report on stratigraphy of the phosphatic shale member of the Phosphoria formation in western Wyoming, southeastern Idaho, and northern Utah : U. S. Geol. Survey open-file report, $162 \mathrm{p}$.

- McKelvey, V. E., and Nelson, J. M., 1950, Characteristics of marine uranium bearing sedimentary rocks : Econ. Geology, v. 45, no. 1, p. 35-53.

* Mansfield, G. R., 1918, Origin of the western phosphates of the United States: Am. Jour. Sci., 4th ser., v. 46, p. 591-598.

*_ 1920, Geography, geology, and mineral resources of the Fort Hall Indian Reservation, Idaho, with a chapter on water resources by W. B. Heroy: U. S. Geol. Survey Bull. 713, 152 p. Map, scale $1: 125,000$.

*__ 1927, Geography, geology, and mineral resources of part of southeastern Idaho: U. S. Geol. Survey Prof. Paper 152, 409 p. Maps, various scales. 1928, Phosphate of the United States, in Opik, A., Les réserves mondiales en phosphates: Madrid, Bureau $14^{\circ}$ Congrés. Géologique International, Espagne, 1926.

*__ 1933, The western phosphate field, in Ore deposits of the Western States (Lindgren volume) p. 491-496: Am. Inst. Min. Metall. Eng.

*ـ 1937, Role of physical chemistry in stratigraphic problems : Econ. Geology, v. 32, p. 535-549.

* 1940, The role of fluorine in phosphate deposition: Am. Jour. Sci., $\nabla$. 238, p. 863-879, 1 fig.

1940, Geology of phosphate deposits in the United States [abs.]: Geol. Soc. America Bull., v. 51, p. 2040-2041.

- Pardee, J. T., 1917, The Garrison and Philipsburg phosphate fields, Montana : U. S. Geol. Survey Bull. 640, p. 195-228. Map, scale 1 : 125,000.

* Penrose, R. A. F., Jr., 1888, Nature and origin of deposits of phosphates of lime: U. S. Geol. Survey Bull. 46, p. 21-143.

* Richards, R. W., and Mansfield, G. R., 1910, Preliminary report on a portion of the Idaho phosphate reserve: U. S. Geol. Survey Bull. 470, p. 371-439. Maps, scales $1 \mathrm{in}$. to $1 \mathrm{mi}$., $1 \mathrm{in}$. to $71 / 2 \mathrm{mi}$.

*_ 1914, Geology of the phosphate deposits northeast of Georgetown, Idaho : U. S. Geol. Survey Bull: 577, 76 p. Maps, scales 1 in. to 1 mi., 1 in. to 4 mi.

- Schuchert, Charles, 1633, Correlation of more important marine Permian sequence: Geol. Soc. America Bull., v. 46, p. 1-46, 1935 ; abs., Pan-Am. Geologist, v. 60, p. 240, Internat. Geol. Cong., 16th sess., United States, 1933, Rept., v. 1, p. 701, 1936. 
Sellards, E. H., 1914, The origin, mining, and preparation of phosphate rock: Am. Inst. Min. Eng. Bull. 93, p. 2379-2395; Trans., v. 50, p. 901-916. [1915].

Surr, Gordon, 1911, Origin and importance of phosphate deposits : Mining World, จ. 34, p. 345-347.

* Telfer, L., 1933, Phosphate in the Canadian Rockies: Canadian Inst. Mining and Metallurgy Trans., v. 36, p. 566-605, [1934] ; Bull. 260, p. 566-605.

* Twenhofel, .W. H., 1932, Treatise on sedimentation: 2d ed., p. 548-552, Baltimore, The Williams \& Wilkins Co.

*White, [G.] David, 1924, Permian of western America from the paleobotanical standpoint : Pan-Pacific Sci. Cong., Australia [1923], Proc. v. 2, p. 1050-1077.

\section{RESERVES, MINING, PRODUCTION, AND UTILIZATION OF WESTERN PHOSPHATE ROCK}

Adams, F. D., 1917, The phosphate discussion: Canadian Min. Jour. v. 38, p. $321-322$.

Anaconda Copper Mining Co., 1924, Report for 1923 (by the president and the chairman of the board of directors), New York.

*Armstrong, R. J., and McKay, J. J., 1949, Mining operations of the Montana Phosphate Products Company : Am. Inst. Min. Metall. Eng. Trans., v. 184, p. 287-291.

Asseciation of Land Grant Colleges and Universities, 1940, Development and utilization of western phosphate [abs.]: Western Phosphate Conf. Proc., Ogden, Utah.

Barr, J. A., 1946, Phosphate: Min. Cong. Jour., v. 32, no. 2, p. 70-71.

Bell, R. E., 1950, Western phosphate industry : Min. Eng., v. 187, p. 486-490.

1951, For the Nation's defense, public domain phosphate: U. S. Dept. Interior, Bur. Land Management, Our Public Lands, v. 1, no. 3, Oct. 1951.

Bell, R. E., and Waggaman, W. H., 1950, Western phosphates ; potential markets : Indus. Eng. Chemistry, v. 42, p. 286-292.

Bell, R. N., 1917, Phosphate deposits of Idaho : Eng. Min. Jour., v. 104, p. 293-294. 1918, Mineral resources of Idaho, in Northwest Mines Handbook, v. 1, p. 30 : Spokane, Wash., Sidney Norman.

1930, Western agricultural minerals : Min. Truth, v. 15, no. 1, p. 5-6, 20, $22,26,28$.

*Bell, R. N., Moore, F. C., and Campbell, S., 1905-1921, Annual reports of the mining industry of Idaho.

Brand, Charles J., 1940, Economic feasibility of expanding the western phosphate industry : Am. Fertilizer, v. 93, no. 7, p. 5-8, 24, 26.

*Brown, L. P., 1912, The phosphate deposits of continental North America: Internat. Cong. Applied Chemistry, 8th, v. 26, p. 87-117.

*Butner, D. W., 1949, Phosphate rock mining in southeastern Idaho: U. S. Bur. Mines Inf. Circ. 7529, 18 p.

*Campbell, M. R., and others, 1915, Guidebook of the western United StatesPart A, The Northern Pacific route with a side trip to Yellowstone Park: U. S. Geol. Survey Bull. 611, 212 p.

Caro, R. J., 1949, Anaconda phosphate plant, beneficiation and treatment of low grade Idaho phosphate rock: Am. Inst. Min. Metall. Eng. Trans., v. 184, p. 282-284.

* Clabaugh, S. E., Larrabee, D. M., and Grifftts, W. R., 1946, Map showing construction materials and nonmetallic mineral resources of Wyoming [with text] : U. S. Geol. Survey Missouri Basin Studies Map 9. Scale 1:500,000.

*Cochran, K. L., 1950, Wyoming phosphate industry : Wyo. Geol. Assoc. Guidebook 5. p. 133-135. 
Cole, Frank, 1930, Status of phosphate industry of western United States : Mining and Metallurgy, v. 11, p. 104-105.

*Condit, D. D., 1924, Phosphate deposits in the Wind River Mountains, near Lander, Wyo.: U. S. Geol. Survey Bull. 764, 39 p. Map, scale 1: 125,000.

*Condit, D. D., Finch, E. H., and Pardee, J. T., 1928, Phosphate rock in the Three Forks-Yellowstone Park region, Mont.: U. S. Geol. Survey Bull. 795, p. 147-209.

[U. S.] Congressional Documents, 1909, Hearings held before the Committee on the Public Lands of the House of Representatives on Dec. 17, 1908, Jan. 13, 15, 16, and Feb. 2, 1909, on H. R. 21873, to define the mannier in which public lands containing valuable deposits of phosphate and phosphate rock may be acquired : Washington, Government Printing Office, [1910].

1939 , Joint committee to investigate the adequacy and use of the phosphate reserves of the United States, 75th Congress, Pub. Resol. 112, Hearings, Washington, Government Printing Office.

*Curtis, H. A., 1938, Western phosphate deposits : Indus. Eng. Chemistrg, v. 30; p. $973-979$.

*Deiss, C. F., 1949, Phosphate deposits of the Deer Creek-Wells Canyon area, Caribou County, Idaho: U. S. Geol. Survey Bull. 955-C, 101 p.

[U. S.] Department of the Interior, 1912, Harry Lode Mining Claim: Decisions [in cases] relating to the public lands, v. 41, p. 403-408, May 1, 1912, to Mar. 15,1913 , Washington, 1913.

*Dietz, C. S., 1929, The developed and undeveloped mineral resources of Wyoming : Wyo. Geol. Survey Bull. 21, p. 85-90, 193.

Duffield, M. S., 1910, Western phosphate mines: Mines and Methods, v. 2, no. 1, p. $9-13$.

Ferrier, W. F., 1917, Phosphate deposits of western United States and Canada: Canadian Min. Jour., v. 38, p. 209-210.

Fisher, C. G., 1930, Phosphate regulations: U. S. General Land Office Circulars and regulations, Circ. 696 , p. 906-913.

- Fowler, H. B., 1949, Phosphate mining by the Simplot Fertilizer Company near Fort Hall, Idaho: Am. Inst. Min. Metall. Eng. Trans., v. 184, p. 291-295.

- 1949, How Simplot solved a complex stripping problem : Ing. Min. Jour. v. 150, no. 10, p. 92-93.

Fuller, R. B., 1951, The history and development of phosphate rock mining: Am. Inst. Min. Metall. Eng. Tech. Pub. 3118-H; Min. Eng., v. 3, p. 708-712.

Gale, H. S., 1911, Rock phosphate near Melrose, Mont.: U. S. Geol. Survey Bull. 470 , p. $440-451$, 3 figs. Map, scale 1 in. to $7 \mathrm{mi}$.

* Gale, H. S., and Richards, R. W., 1910, Preliminary report on the phosphate deposits in southeastern Idaho and adjacent parts of Wyoming and Utah : U. S. Geol. Survey Bull. 430, p. 457-535. Maps, scale 1:62,500.

* Gardner, L. S., 1944, Phosphate deposits of the Teton Basin area, Idaho and Wyoming: U. S. Geol. Survey Bull. 944-A, 36 p. Maps, scale 1: 48,000.

Gilbert, Geoffrey, 1944, Operations of Montana Phosphate Products Co. : Mining and Metallurgy, v. 25, no. 454, p. 486-487.

Green, Jack, and Young, W. A., Jr., 1937, The Park City mining district [Utah] : Compass, v. 17, p. 159-162.

Hanson, A. M., 1942, Phosphate deposits in western Summit, Wasatch, Salt Iake, Morgan, and Weber Counties, Utah: Utah State Agr. Coll., Logan, Utah., unpub. thesis.

Hodge, E. T., 1940, Mineral resources of the Northwest [abs.] : Geol. Soc. America Bull., v. 51, pt. 2, p. 2025.

Huttl, J. B., 1930, Phosphate mining and milling at Conda, Idaho: Fng. Min. Jour., v. 129, p. 195-196. 
* [Idaho] Inspector of Mines, 1922-1948, Annual reports of the mining industry of Idaho.

Idaho Phosphate Commission, 1938, The present economic aspect of Idaho's phosphate (and appendix) : Boise, Idaho.

Idaho, University of, Phosphate Committee, 1938, The University of Idaho and the development of Idaho phosphates-a progress report: Idaho Univ. Bull., v. 33, no. 2.

* Jacob, K. D., 1938, The phosphate rock reserves of the United States: Commercial Fertilizer Yearbook, p. 28-43, 55, 59.

- 1944, Uses of phosphate: Mining and Metallurgy, v. 25, no. 454, p. 488-491.

Jacob, K. D., and Hill, W. L., 1933, Occurrence, production and reserves of phosphate rock in the United States: Am. Fertilizer, v. 78, no. 8, p. 7-9.

Jacob, K. D., Hill, W. L., and Marshall, H. L., 1983, The composition and distribution of phosphate rock with special reference to the United States: U. S. Dept. Agriculture Tech. Bull. 364, 90 p.

Jacob, K. D., and Reynolds, D. S., 1928, The fluorine content of phosphate rock: Assoc. Off. Agr. Chemists Jour., v. 11, p. 242-250.

Jacob, K. D., Reynolds, D. S., and Marshall, H. L., 1936, Phosphate fertilizer by calcination process-volatilization of fluorine from phosphate rock at high temperatures: Am. Inst. Min. Metall. Eng. Tech. Pub. 695, 14 p.

Jamison, C. E., 1911, Mineral resources of Wyoming: Wyo. State Geologist, Ser. B, Bull. 1, p. 37 .

Johnson, A. C., and Davis, C. W., 1945, War development proves large vanadium reserves [United States] : Eng. Min. Jour., v. 146, p. 105-107, April.

* Johnson, B. L., 1930, Phosphate rock: U. S. Bur. Mines Inf. Circ. 6256, 64 p.; abs., Phosphate rock, locations of deposits and mining methods employed: Pit and Quarry, v. 20, p. 44-46, May 21.

- 1944, Economic factors in the U. S. phosphate industry : Mining and Metallurgy, v. 25, p. 455-465.

1945, The phosphate rock deposits and industry of the Western States [abs.] : Econ. Geology, v. 40, no. 1, p. 87-88.

Johnson, R. M., and Cole, Frank, 1923, The phosphate plant (at Anaconaa, Mont.) : The Anode, v. 9, no. 10, p. 1-4, Butte, Mont., Anaconda Copper Mining Co.

* Jones, C. C., 1907, Phosphate rock in Utah, Idaho, and Wyoming: Eng. Min. Jour. v. 83, p. 953-955.

* 1913, The discovery and opening of a new phosphate field in the United States: Am. Inst. Min. Eng. Bull. 82, p. 2411-2435; Trans. v. 47, p. 192-216, 1914.

Katz, F. J., 1922, Phosphate rock : U. S. Bur. Census, 14th Census U. S., Mines and Quarries 1919.

* King, D. L., 1949, Surface strip phosphate mining at Leefe, Wyoming, and Montpelier, Idaho: Am. Inst. Min. Metall. Eng. Trans., v. 184, p. 284-287.

* King, R. H., 1947, Phosphate deposits near Lander, Wyo.: Wyo. Geol. Survey Bull. 39, 84 p. Maps, scales 1 in. to $500 \mathrm{ft} ., 1$ in. to $2 \mathrm{mi}$.

* King, W. H., and Schumacher, J. I., 1949, Investigation of the Lander phosphate rock deposits, Fremont County, Wyo.; U. S. Bur. Mines. Rept. Inv. 4437.

King, W. H., and Wilson, S. R., 1949, Diamond drill and auger sampling of vanadiferous shales, Mercur Dome mine, Tooele County, Utah: U. S. Bur.

$\therefore$ Mines Rept. Inv. 4572. 
Kirkham, V. R. D., 1922, Idaho phosphate industry [abs.] : Am. Fertilizer, v. 57, no. 13 , p. 76,78 .

*_ 1925, Phosphate deposits of Idaho and their relation to the world supply: Am. Inst. Min. Metall. Eng. Trans. [prepr.] 1405, 28 p.; with discussion, Trans., v. 71, p. 308-338; Idaho Bur. Mines and Geology Repr. 1; abs., Mining and Metallurgy, v. 6, no. 221, p. 247-248.

Larison, E. L., 1929, Manufacture of high-analysis phosphates: Indus. Eng. Chemistry, v. 21, p. 1172-1175.

Livingston, D. C., 1918, Geology of Idaho, in Northwest Mines Handbook, v. 1, p. 21-26, Spokane, Wash., Sidney Norman.

* Long, A. E., 1949, Experimental diamond drilling in the Phosphoria formation in southeastern Idaho: U. S. Bur. Mines Rept. Inv. 4597, 29 p.

* McHugh, G. A., 1950, Western phosphate: Min. Cong. Jour., v. 36, No. 2, p. 120-122.

* Mansfield, G. R., 1915, Geology of the Fort Hall Indian Reservation, Idaho [abs.] : Wash. Acad. Sci. Jour., v. 5, p. 492-493.

- 1917, The phosphate resources of the United States : Pan-Am. Sci. Cong., 2d, Proc., sec. 7, v. 8, p. 729-766.

*_ 1920, Geography, geology, and mineral resources of the Fort Hall Indian Reservation, Idaho, with a chapter on water resources by W. B. Heroy : U. S. Geol. Survey Bull. 713, 152 p. Map, scale $1: 125,000$.

_ 1926, Phosphate reserves ample for 2,000 years: Eng. Min. Jour., v. 122, p. 810-814.

*__ 1927, Geography, geology, and mineral resources of part of southeastern Idaho: U. S. Geol. Survey Prof. Paper 152, 409 p. Maps, various scales. 1927, How the fertilizer minerals of commerce are distributed: Eng. Min. Jour., v. 123, p. 567-570.

1928, Phosphate of the United States, in Opik, A., Les reserves mondiales en phosphates: Madrid, Bureau $14^{\circ}$ Congrés Geologique International Espagne, 1926.

*— 1928, The Idaho phosphate field: Mining and Metallurgy, v. 9, p. 19-20.

- 1929, Geography, geology and mineral resources of the Portneuf quadrangle, Idaho: U. S. Geol. Survey Bull. 803,110 p. Map, scale 1 in. to $1 \mathrm{mi}$.

*_ 1933, The western phosphate field, in Ore deposits of the Western States (Lindgren Volume) p. 491-496: Am. Inst. Min. Metall. Eng.

*_ 1940, Phosphate deposits of the United States : Econ. Geology, v. 35, p. 423-429 ; abs., Geol. Soc. America Bull., v. 51, p. 2040-2041.

1940, The role of fluorine in phosphate deposition: Am. Jour. Sci., v. 238, p. $863-879$.

- 1940, Recent studies of reserves of domestic phosphate: Am. Inst. Min. Metall. Eng. Tech. Pub. 1208, 10 p.; repr., Trans., v. 148, 1942.

1942, Phosphate deposits of the world with special reference to those of the United States: Indus. Eng. Chemistry, v. 34, p. 9-12.

Martin, H. S., and Wilding, James, 1937, Phosphate rock, in Industrial minerals and rocks : Am. Inst. Min. Metall. Eng., p. 550-553.

Marzel, J. G., 1928?, Fourteenth biennial report of the State Geologist of the State of Wyoming, October 1, 1926-September 30, 1928.

1929, Developed and undeveloped mineral resources of Wyoming: Wyo. Geol. Survey Bull. 21, p. 85-90.

* 1930, Fifteenth biennial report of the State Geologist of the State of Wyoming, October 1, 1928-September 30, 1930.

Mineral Industry, v. 15, 1906 to 1949: McGraw-Hill Book Co., Inc., New York and London. 
Miller, G. W., 1904, Geology of the Butte mining district, Mont.: Ores and Metals, v. 13, no. 10, p. 15-16; no."11, p. 19-20.

* Newton, Joseph, 1944?, Phosphates: Idaho Bur. Mines and Geology Inf. Leaflet 13 .

* Newton, Joseph, and Finklenburg, O. C., 1947, Beneficiation of Idaho phosphate rock: Idaho Bur. Mines and Geology Min. Res. Rept. 3, 22 p.

Nighman, C. E., 1923, Phosphate mines at Conda, Idaho: Anode, v. 9, no. 9, p. 1-6, Butte, Mont., Anaconda Copper Mining Co.

Norris, E. M., 1944, Underground mining of phosphate rock at Conda, Idaho: Mining and Metallurgy, v. 25, no. 454, p. 481-485.

Noyes, F. C., 1944, Phosphate rock industry of foreign countries: Mining and Metallurgy, v. 25, no. 454, p. 495-506.

* Pardee, J. T., 1913, Some further discoveries of rock phosphate in Montana: U. S. Geol. Survey Bull. 530, p. 285-291. Map, scale 1 in. to $12 \mathrm{mi}$.

*__ 1917, The Garrison and Philipsburg phosphate fields, Montana: U. S. Geol. Survey Bull. 640, p. 195-228. Map, scale 1: 125,000.

*__ 1921, Phosphate rock near Maxville, Granite County, Mont. : U. S. Geol. Survey Bull. 715, p. 141-145. Map, scale 1: 125,000.

*—_ 1936, Phosphate rock near Maxville, Philipsburg, and Avon, Mont.: U. S. Geol. Survey Bull. 847-D, p. 175-18s. Maps, scale 1 in. to $1 \mathrm{mi}$.

Phalen, W. C., 1917, The conservation of phosphate rock in the United States: Pan-Am. Sci. Cong, 2d, Proc., sec. 7, v. 8, p. 772-808; Am. Inst. Min. Eng. Bull. 119, p. 1901-1934, 1918 ; Trans., v. 57, p. 99-132, 1918.

Pike, R. D., 1930, Volatilization of phosphorous from phosphate rock, I-Experiments in crucibles and rotary kiln : Indus. Eng. Chemistry, v. 22, p. 242-245. -1930, Volatilization of phosphorous from phosphate rock, II-Experiments in volatilization of phosphorous and potash in a blast furnace: Indus. Eng. Chemistry, v. 22, p. 344-349.

1930, Volatilization of phosphorous from phosphate rock, III-Calculations of performance of a blast furnace for volatilization of phosphorous and potash : Indus. Eng. Chemistry, v. 22, p. 349-354.

Richards, R. W., 1913, Methods of field work in the phosphate districts of Idaho, Montana, Wyoming, and Utah [discussion] : Econ. Geology, v. 8, p. 181-188.

* Richards, R. W., and Mansfield, G. R., 1910, Preliminary report on a portion of the Idaho phosphate reserve: U. S. Geol. Survey Bull. 470, p. 371-439. Map, scales 1 in. to $1 \mathrm{mi}$., 1 in. to $71 / 2 \mathrm{mi}$.

* Richardson G. B., 1941, Geology and mineral resources of the Randolph quadrangle, Utah-Wyo. : U. S. Geol. Survey Bull. 923, 54 p.

* Richter, Albert, 1911, Western phosphate discovery: Mines and Methods, v. 2, no. 9 , p. 207.

Royster, P. H., 1937, Blast furnace processes for the production of phosphatic and potassic fertilizer materials: U. S. Dept. Agriculture Tech. Bull. 543.

* Russell, T. C., 1949, Mining of phosphate rock at Conda, Idaho: Am. Inst. Min. Metall. Eng. Trans.; v. 184, p. 279, 282.

* Sahinen, U. M., 1937, Phosphate rock in Montana : Glück Auf, v. 2, no. 3, p. 10-11. Butte, Mont.

* Schereschewsky, Ph., 1947, Les mines de phosphate des Montagnes Rocheuses: Annales mines Mem., an. 136, no. 1, p. 69-83.

* Schneider, Hyrum, 1919, General geology of Utah, in The Mineral Industry of Utah: Utah Univ. Bull., v. 10, no. 11 (Eng. Sta., Dept. Metall. Research Bull. 12), p. 3-33, 89-91. 
* Schultz, A. R., 1918, A geologic reconnaissance for phosphate and coal in southeastern Idaho and western Wyoming: U. S. Geol. Survey Bull. 680, 84 p. Maps, various scales.

*_ 1918, A geologic reconnaissance of the Uinta Mountains; northern Utah, with special reference to phosphate: U. S. Geol. Survey Bull. 690, p. 31-94. Maps, scale 1 in. to $7 \mathrm{mi}$., $1 \mathrm{in}$. to $24 \mathrm{mi}$.

- Schultz, A. R., and Richards, R. W., 1913, A geologic reconnaissance in southeastern Idaho: U. S. Geol. Survey Bull. 530, p. 267-284. Maps, scale 1 in. to $71 / 2 \mathrm{mi}$.

Sellards, E. H., 1914, The origin, mining, and preparation of phosphate rock: Am. Inst. Min. Eng. Bull. 93, p. 2379-2395. Trans. v. 50, p. 901-916, 1915.

Smith, G. O., and others, 1913, The classification of the public lands: U. S. Geol. Survey Bull. 537, p. 8, 39-40, 123-134.

* Stipp, T. F., and French, H. F., 1944, Geologic and structure map of the Little Buffalo Basin oil and gas field and vicinity, Park and Hot Springs Counties, Wyo.: U. S. Geol. Survey. Scale, 1 in. to $2 \mathrm{mi}$.

Stone, R. W., in McCaskey, H. D., and Burchard, E. F., 1919, Our mineral supplies : U. S. Geol. Survey Bull. 666, p. 57-60.

Stone, R. W., 1919, Phosphate rock an economic army [abs.]: Geol. Soc. America Bull., v. 30, p. 104.

* Stone, R. W., and Bonine, C. A., 1914, The Elliston phosphate field, Montana: U. S. Geol. Survey Bull. 580, p. 373-383. Map, scale 1 in. to 1 mi.

Stone, S. R., 1912, Phosphate deposits and mining methods in U. S. : Min. and Eng. World, v. 36, p. 511-512.

Surr, Gordon, 1911, Origin and importance of phosphate deposits : Min. World, v. 34 , p. $345-347$.

* Swenson, F. A., 1942, Geology of the northwest flank of the Gros Ventre Mountains, Wyo. : Iowa Univ, unpub. dissert., 100 p. ; abs., Iowa Univ. Pub., Aims and Prog. Research ser. no. 71, 1 p., unnumbered. Map, scale 1 in to $13 / / \mathrm{mi}$.

* Thomas, C. S., 1949, Rock phosphate mining, Rocky Mountain region: Min. Yearbook, p. 53, 55. Colorado Mining Assoc.

Thomson, F. A., 1948, A preliminary inventory of Montana mineral resources: $2 d$ ed., U. M. Sahinen, editor, p. 12, 13, 16, Mont. Bur. Mines and Geology.

Trumbull, L. W., 1914, Biennial report, 1913-1914: Wyo. Geologists Off., Ser. B, Bull. 9, p. 149-168.

Tullis, E. L., 1932, The development of Idaho's nonmetallic resources: Pit and Quarry, v. 23, no. 12, p. 22-27.

Tyler, P. M., and Johnson, B. L., 1938, The phosphate situation: Mining and Metallurgy, v. 19, p. 389-393.

United States Bureau of Mines, 1925-1933 [annually], Mineral resources of the United States.

United States Bureau of Mines, 1934-1950 [annually], Minerals Yearbook.

United States Geological Survey, 1906-1925 [annually], Mineral resources of the United States.

United States Works Projects Administration, 1940, Mineral Resources Survey, Directory of Montana mining properties: Mont. Bur. Mines and Geology Mem. 20, 135 p.

Utley, H. F., 1951, Idaho's vast phosphate beds yield raw material for big operations : Pit and Quarry, v. 43, no. 11, p. 83-85.

Van Horn, F. B., 1909, The phosphate deposits of the United States: U. S. Geol. Survey Bull. 394, p. 157-171; (60th Cong., 2d sess. S. Doc. 676) Nat. Conservation Comm. Rept. 3, p. 558-570; abs., Min. Sci. Press, v. 99, p. 88-90.

1911, Phosphate and potash deposits : Am. Fertilizer, v. 35, p. 68-70.

1911, Phosphate deposits of the United States [abs.]: Wash. Acad. Sci.

Jour., v. 1, p. 293-294.

$296348-54-6$ 
Varley, Thomas, Wright, C. A., and Soper, E. K., 1919, A preliminary report on the mining districts of Idaho : U. S. Bur. Mines Bull. 166, 89 p.

* Waggaman, W. H., 1910, A review of the phosphate fields of Idaho, Utah and Wyoming with special reference to the thickness and quality of the deposits :

U. S. Dept. Agriculture, Bur. Soils Bull. 69, 48 p.

1914, The manufacture of acid phosphate: U. S. Dept. Agriculture Bull. $144,28 \mathrm{p}$.

1914, The reserve supply of phosphate rock in the United States: Indus. Eng. Chemistry, v. 6, p. 464-465.

*_ 1927, Phosphoric acid, phosphates, and phosphate fertilizer: New York, The Chemical Catalog, Inc., p. 76-80.

1939, Our phosphate reserves: Chem. Metall. Eng., v. 46, p. 66-68.

Waggaman, W. H., and Bell, R. E., 1950, Western phosphates; factors affecting development: Indus. Eng. Chemistry, v. 42, p. 269-276.

- 1950, Western phosphates ; comparison of sulphuric acid and thermal reduction processing : Indus. Eng. Chemistry, v. 42, p. 276-286.

Waggaman, W. H., and Fry, W. H., 1915, Phosphate rock and methods proposed for its utilization as a fertilizer: U. S. Dept. Agriculture Bull. 312, $37 \mathrm{p}$.

Weeks, F. B., 1908, Phosphate deposits in the western United States: U. S. Geol. Survey Bull. 340, p. 441-447.

Whitlock, G. I., 1938, The University of Idaho and the development of Idaho phosphates: Idaho Univ. Bull., v. 33, 19 p.

-Williams, J. Stewart, 1939, Phosphate in Utah: Utah Agr. Exper. Sta. Bull. 290, 44 p. Maps, 1 in. to about 2 mi.

Williams, J. Stewart, and Hanson, A. M., 1942, Phosphate reserves of Utah (revised estimate) : Utah Agr. Exper. Sta. Bull. 304, Supp. to Bull. 290, 24 p. Maps, scales about $1 \mathrm{in}$. to $61 / 2 \mathrm{mi}$., 1 in. to $71 / 2 \mathrm{mi}$.

Anonymous, 1926, A large western phosphate operation: Rock Products, v. 29, p. 65 , June 26 .

1928, Openings of mineral land by Interior Department: Mining Truth, v. 13, no. 16, p. 4 .

1938, What about western phosphates?: Chem. Metall. Eng., v. 45, p. $486-487$.

- 1949, Open-pit phosphate mine : Rock Products, v. 52, no. 6, p. 104-105.

1949, Over a million tons of earth moved to get phosphate ore: Pit and Quarry, v. 42, no. 1, p. 161-162.

1949, Western phosphate described : Min. Eng., v. 1, no. 4, p. 28.

1949, Western phosphate output soars : Eng. Min. Jour., v. 150, p. 130-133.

1951, Industry developing phosphate deposits in Missouri Basin: Rocks and Minerals, v. 26, nos. 5-6, p. 272-273, 282.

OIL, BITUMINOUS MATERIAL, VANADIUM, AND MINOR ELEMENTS IN THE PHOSPHORIA FORMATION AND ITS PARTIAL STRATIGRAPHIC EQUIVALENTS IN THE WESTERN FIELD

* Adams, F. D., and Dick, W. J., 1917, Discovery of phosphate of lime in the Rocky Mountains [with discussion by W. F. Ferrier and L. D. Burling] : Canadian Min. Inst. Trans., v. 19, p. 321-348.

*Allsman, P. T., Majors, F. H., and Mahoney, S. R., 1949, Investigation of Sublette Ridge vanadium deposit, Lincoln County, Wyo.: U. S. Bur. Mines Rept. Inv. 4476.

*__ 1949, Investigation of Salt: River Range vanadium deposits, Lincoln County, Wyo. : U. S. Bur. Mines Rept. Inv. 4503. 
* Andrews, D. A., 1944, Oil and gas in the Maverick Springs area, Fremont County, Wyo.: U. S. Geol. Survey Oil and Gas Inv. Prelim. Map 13. Scale, 1 in. to $3 / 4 \mathrm{mi}$.

Argall, G. O., Jr., 1943, The occurrence and production of vanadium : Colo. School Mines Quart., v. 38, p. 17.

Axelrod, J. M., 1946, A field test for vanadium: U. S. Geol. Survey Bull. 950, p. 19-23.

* Barton, H. E., 1948, Steamboat Butte oil field, Fremont County, Wyo., in Structure of typical American oil fields, v. 3, p. 480-513: Am. Assoc. Petroleum Geologists.

* Bartram, J. G., 1926, Occurrence of black oil in Wyoming: Am. Assoc. Petroleum Geologists Bull., v. 10, p. 443-448.

* 1932, Character of producing sandstones and limestones of Wyoming and Montana: Am. Assoc. Petroleum Geologists Bull. v. 16, p. 870-873.

* Boutwell, J. M., 1912, Geology and ore deposits of the Park City district, Utah : U. S. Geol. Survey Prof. Paper 77, 231 p.; abs., Wash. Acad. Sci. Jour., v. 3, p. 445-447.

- Bowen, C. F., 1918, Phosphatic oil shales near Dell and Dillon, Beaverhead County, Mont. : U. S. Geol. Survey Bull. 661, p. 315-320.

* Brainerd, A. E., 1940, Big Muddy field, Converse County, Wyo. : Kans. Geol. Soc. Guidebook 14, p. 148-149.

* Branson, E. B., and Branson, C. C., 1941, Geology of Wind River Mountains, Wyo.: Am. Assoc. Petroleum Geologists Bull. 25, p. 120-151; abs., Oil and Gas Jour., v. 38 , no. 48, p. 55, 1940. Map, scale 1 in. to about $7 \mathrm{mi}$.

* Breger, C. L., 1911, Origin of Lander oil and western phosphate: Min. Eng. World, v. 35, p. 631-633.

* Buranek, A. M., 1948, Fluorite in Utah; its occurrence, extent, and significance to Utah industry : Utah Dept. Publicity Ind. Devel., Circ. 36, p. 13.

* Carroll, D. L., 1944, Interest revived in Wyoming and Montana: Oil Weekly, v. 113, no. 2 , p. 18, 22, 24.

* Christensen, H. E., and Marshall, John, 1950, La Barge field, Lincoln and Sublette Counties, Wyo.: Wyo. Geol. Assoc. Guidebook 5, p. 105-108.

* Clark, F. R., 1919, Farnham anticline, Carbon County, Utah : U. S. Geol. Survey Bull. 711, p. 8, 13.

- Collier, A. J., 1920, Anticlines near Maverick Springs, Fremont County. Wyo. : U. S. Geol. Survey Bull. 711, p. 149-171:

*_ 1920, Oil in the Warm Springs and Hamilton domes, near Thermopolis, Wyo. : U. S. Geol. Survey Bull. 711, p. 61-73.

* Condit, D. D., 1919, Oil shale in western Montana, southeastern Idaho, and adjacent parts of Wyoming and Utah : U. S. Geol. Survey Bull. 711, p. 15-40; abs., Wash. Acad. Sci. Jour., v. 9, p. 638.

* Dietz, C. S., 1929, The developed and undeveloped mineral resources of Wyoming: Wyo. Geol. Survey Bull. 21, p. 85-90, 193.

* Dobbin, C. E., 1943, Structural conditions of oil and gas accumulation in Rocky Mountain region, United States: Am. Assoc. Petroleum Geologists Bull., v. 27, p. $417-478$.

* Dorn, C. $\dot{\mathrm{L}}$., 1949, Developments in Rocky Mountain region in 1948; Am. Assoc. Petroleum Geologists Bull., v. 33, p. 827-836.

Duffield, M. S., 1910, Western phosphate mines: Mines and Methods, v. 2, no. 1, p. $9-13$.

* Espach, R. H., and Nichols, H. D., 1941, Petroleum and natural gas fields in Wyoming : U. S. Bur. Mines Buil 418, 185 p.

Fahrenwald, A. W., 1941, ${ }^{\circ}$ Strategic minerals in Idaho: Idaho Univ., Bur. Mines and Geology Press Bull. 20, p. 3. 
* Fidlar, M. M., 1950, Baxter Basin gas fields, Sweetwater County, Wyo.: Wyo. Geol. Assoc. Guidebook 5, p. 109-110.

* 1950, Clay Basin gas field, Daggett County, Utah: Wyo. Geol. Assoc. Guidebook, 5, p. 114-116; map, scale 1 in. to $4000 \mathrm{ft}$.

Gardner, L. S., 1944, Phosphate deposits of the Teton Basin area, Idaho and Wyoming: U. S. Geol. Survey Bull. 944-A, 36 p. Maps, scale 1:48,000.

* Heald, K. C., 1921, The oil bearing horizons of Wyoming : Am. Assoc Petroleum Geologists Bull., v. 5, p. 191-192.

* Heaton, R. L., 1937, Stratigraphy versus structure in Rocky Mountain region: Am. Assoc. Petroleum Geologists Bull., v. 21, p. 1251-1258.

* Hewitt, E. A., 1928, Exploration methods in the Park City, Utah, district: Min. Cong. Jour., v. 12, p. 54-55.

Hill, W. L., and Jacob, H. D., 1933, Determination and occurrence of iodine in phosphate rock: Jour. Assoc. Off. Agr. Chem., v. 16, p. 128-137.

Hill, W. L., Marshall, H. L., and Jacob, K. D., 1932, Minor metallic constituents of phosphate rock: Indus. Eng. Chemistry, v. 24, p. 1306-1312.

Idaho, University of, Phosphate Committee, 1938, The University of Idaho and the development of Idaho phosphates [progress report]: Idaho Univ. Bull., v. 33 , no. 2 .

* Jacob, K. D., Hill, W. L., and Marshall H. L., 1933, The composition and distribution of phosphate rock with special reference to the United States: U. S. Dept. Agriculture Tech. Bull. 364, 90 p.

Jacob, K. D., Reynolds, D. S., and Marshall, H. L., 1938, Phosphate fertilizers by calcination process-volatilization of fluorine from phosphate rock at high temperatures: Am. Inst. Min. Metall. Eng. Trans., v. 129, p. 315-328.

Johnson, A. C., and Davis, C. W., 1945, War development proves large vanadium reserves : Eng. Min. Jour., v. 146, p. 105-107.

* Johnson, B. L., and Tucker, E. M., 1945, Phosphate rock: Minerals Yearbook, 1945, p. 1-19.

* Kinney, D. M., and Rominger, J. F., 1947. Geology of the Whiterocks RiverAshley Creek area, Uintah County, Utah: U. S. Geol. Survey Oil and Gas Inv. Prelim. Map 82. Scale 1 in. to $1 \mathrm{mi}$.

* Kirkham, V. R. D., 1922, Petroleum possibilities of certain anticlines in southeastern Idaho: Idaho Bur. Mines and Geology Bull. 4, 36 p. Maps, scale $1 \mathrm{in}$. to $1 \mathrm{mi}$.

* __ 1923, Notes on the geology of eastern Bear Lake County, Idaho, with reference to oil possibilities: Idaho Bur. Mines and Geology Pamph. 7, 6 p.

* 1924, Geology and oil possibilities of Bingham, Bonneville, and Caribou Counties, Idaho: Idaho Bur. Mines and Geology Bull. 8, 108 p. Maps, scale 1 in. to about $13 / 8 \mathrm{mi}$.

*_ 1925, Oil possibilities of southeastern Idaho: Mining and Metallurgy, v. 6, p. 71-74.

* Krampert, E. W., 1948, Dallas oil field, Fremont County, Wyo: Wyo. Geol. Soc. Guidebook 3, p. 153-155.

*— 1948, The Lander-Hudson oil field, Fremont County, Wyo.: Wyo. Geol. Assoc. Guidebook 3, p. 148-152.

*—_ 1948, Sand Draw gas and oil field, Fremont County, Wyo.: Wyo. Geol. Assoc. Guidebook 3, p. 156-159.

* La Fleiche, Pierre, 1944, Geologic aspect of Wyoming and outlook for development [of oil and gas fields] : Oil and Gas Jour., v. 43, p. 38, 41-42.

*__ 1945, Wyoming-Pt. 1, General geologic features: Oil Weekly, v. 118, no. 5, p. 30-33; Pt. 2, Oil and gas prospects, no. 8, p. 46-50. Maps, small scale. 
* Lupton, C. T., and Condit, D. D., 1917, Gypsum in the southern part of the Bighorn Mountains, Wyo.: U. S. Geol. Survey Bull. 640, p. 139-157. Map, scale $1 \mathrm{in}$. to about $13 \mathrm{mi}$.

* Lupton, C. T., and Lee, W. T., 1921, Geology of the Cat Creek oil field, Fergus and Garfield Counties, Mont.: Am. Assoc. Petroleum Geologists Bull. 5, p. 259.

* McCabe, W. S., 1947, The Elk Basin field, Park County, Wyoming, and Carbon County, Mont. [abs.], in Am. Assoc. Petroleum Geologists - Soc. Econ. Paleontologists and Mineralogists - Soc. Econ. Geophysicists Joint Ann. Mtg., Los Angeles, March 24-27, Program, p. 29.

1948, Elk Basin anticline, Park County, Wyo., and Carbon County, Mont. : Am. Assoc. Petroleum Geologists Bull., v. 32, p. 59, 67.

McCabe, W. S., and Walker, C. L., 1948, Winkleman Dome, Fremont County, Wyo. : Wyo. Geol. Soc: Guidebook 3, p. 167-173.

* McKelvey, V. E., 1946, Preliminary report on stratigraphy of the phosphatic shale member of the Phosphoria formation in western Wyoming; southeastern Idaho, and northern Utah: U. S. Geol. Survey open-file report, $162 \mathrm{p}$.

* McKelvey, V. E., and Nelson, J. M., 1950, Characteristics of marine uranium bearing sedimentary rocks : Econ. Geology, v. 45, p. 35-53.

Mansfield, G. R., 1927, Geography, geology and mineral resources of part of southeastern Idaho: U. S. Geol. Survey Prof. Paper 152, 453 p. Maps, various scales.

1928, Phosphate [reserves] of the United States in Opik, A. Les reserves mondiales en phosphates: Madrid, Bureau $14^{\circ}$ Congrés Géologique International, Espagne, 1926.

1929, Geography, geology, and mineral resources of the Portneuf quadrangle, Idaho: U. S. Geol. Survey Bull. 803,110 p. Map, scale 1 in. to $1 \mathrm{mi}$. 1940, The role of fluorine in phosphate deposition: Am. Jour. Sci., v. 238, p. 863-879.

Marshall, H. L., Jacob, K. D., and Reynolds, D. S., 1932, Occurrence of fluorine in natural phosphates-further studies: Indus. Eng. Chemistry, v. 24, p. 86-89.

Marzel, J. G., 1928, Fourteenth biennial report of the State geologist of the State of Wyoming, October 1, 1926-September 30, 1928.

*Morgan, G. B., 1921, A real geology of Wyoming; correlation table and production data (on reverse of geological map of Wyoming) : $3 d$ ed., Cheyenne, Wyo., G. B. Morgan and G. S. Hill. Scale 1 in. to $18 \mathrm{mi}$.

*Newton, Joseph, 1944?, Phosphates: Idaho Bur. Mines and Geology Inf. Leaflet 13.

*Olson, W. G., 1948, Circle Ridge and Marerick Springs oil fields, Fremont County, Wyo.: Wyo. Geol. Assoc. Guidebook 3, p. 178-185.

Fardee, J. T., 1936, Phosphate rock near Maxville, Philipsburg, and Avon, Mont. : U. S. Geol. Survey Bull. 847-D, p. 175-18S. Map, scale 1 in. to $1 \mathrm{mi}$.

Perry, E. S., 1937, Natural gas in Montana : Mont. Bur. Mines and Geology Mem. 3, p. 4, 15 .

*ــ 1945, Distribution of sedimentary rocks in Montana and the northwestern Great Plains: Mont. Bur. Mines and Geology Misc. Contrib. 8, p. 8 and map facing, correlation chart at end.

*ـ_ 1949, Gypsum, lime, and limestone in Montana : Mont. Bur. Mines and Geology Mem. 29, 45 p.

Phillips, A. H., 1918, A possible source of vanadium in sedimentary rocks: Am. Jour. Sci., 4th ser., v. 46 , p. $473-475$. 
Kader, L. F., and Hill, W. L., 1938, Determination and occurrence of boron in natural phosphates, superphosphate and defluorinated phosphate rock : Jour. Agr. Research, v. 57, p. 901-914.

Ravitz, S. F., Nicholson, I. W., and Chindgren, 1947, Treatment of Idaho-Wyoming. vanadiferous shales: Am. Inst. Min. Metall. Eng. Tech. Pub. 2178, 14. p.

Reynolds, D. S., Jacob, K. D., and Hill, W. L., 1929, Ratio of fluorine to phosphoric acid in phosphate rock : Ind. Eng. Chemistry, v. 21, p. 1253-1256.

*Richmond, G. M., 1945, Geology and oil possibilities at the northwest end of theWind River Mountains, Sublette County, Wyo.: U. S. Geol. Survey Oil and: Gas Inv. Prelim. Map 31. Scale, 1 in. to $1 \mathrm{mi}$.

*Rubey, W. W., 1943, Vanadiferous shales in the Phosphoria formation, Wyo. and Idaho [abs.] : Econ. Geology, v. 38, p. 87.

Schultz, A. R., 1920, Oil possibilities in and around Baxter Basin, in the Rock Springs uplift, Sweetwater County, Wyo.: U. S. Geol. Survey Bull. 702, p. 79-82, 101-103, pl. 1, charts facing p. 36 and 82. Map, scale $1: 250,000$.

*Sears, J. D., 1924, Geology and oil and gas prospects of parts of Moffat County, Colo., and southern Sweetwater County, Wyo.: U. S. Geol. Survey Bull. 751, p. 283-284, 314-318. Map, scale 1: 125,000.

1926, Geology of the Baxter Bașin gas field, Sweetwater County, Wyo.: U. S. Geol. Survey Bull. 781, p. 17.

-Severy, C. L., and McLarty, D. M. E., 1950, Developments in Rocky Mountain region in 1949 : Am. Assoc. Petroleum Geologists Bull., v. 34, no. 6, p. 10321042.

Sharkey, H. H. R., Love, J. D., and Kirby, Jewell, 1945, Map of Wyoming showing: test wells for oil and gas, anticlinal axes, and oil and gas fields: U. S. Geol. Survey Oil and Gas. Inv. Prelim. Map 19. Scale 1 : 500,000.

*Sielaff, R. L., 1940, Oil fields of the Ferris-Lost Soldier district, Carbon County, Wyo. : Kans. Geol. Soc. Guidebook 14, p. 161-162.

"Summerford, H. E., 1948, Résumé of the oil and gas structures immediately adjacent to the southeastern margin of the Wind River Basin: Wyo. Geol. Assoc. Guidebook 3, p. 186-194.

Taylor, F. B., 1941, West central Wyoming outlook brightened by deeper pays: Oil Weekly, v. 102, no. 2, p. 24, 26, 28, 30, 32 .

* Telfer, L., 1933, Phosphate in the Canadian Rockies: Canadian Inst. Min. Metall. Trans., v. 36, p. 566-605, 1934 : Bull. 260 , p. 566-605.

Thomson, F. A., 1948, A preliminary inventory of Montana mineral resources: $2 \mathrm{~d}$ ed., U. M. Sahinen editor, p. 12, 13, and 16, Mont. Bur. Mines and Geology.

*Trumbull, L. W., 1917, Petroleum geology of Wyoming: 81 p., Cheyenne, Wyo., G. G. Bovee.

* Twenhofel, W. H., 1932, Treatise on sedimentation: 2d ed., p. 548-552, Baltimore, Williams \& Wilkins Co.

United States Geological Survey, 1946, Oil and gas fields of the United States. Map, scale 1 : 2,500,000.

* Uren, L. C., 1938, Economics and geology of the Rocky Mountain area: World Petroleum, v. 9, no. 8, p. 34-49; no. 9, p. 50-64; no. 10, p. 46-62.

* Ver Wiebe, W. A., 1930, Oil fields in the United States: p. 447-558, New York, McGraw-Hill Book Co.

1949, Oil fields in North America : 251 p., Wichita, Kans., Edwards Bros.

*Walton, P. T., 1947, Oregon Basin oil and gas field, Park County, Wro.: Am. Assoc. Petroleum Geologists Bull., v. 31, p. 1431-1453; abs., Am. Assoc. Petroleum Geologists-Soc. Econ. Paleontologists and Mineralogists-Soc. Econ. Geophysicists Joint Ann. Mtg. Los Angeles, March 24-30, Program, p. 28-29. 
Warren, P. S., 1927, Banff Area, Alberta: Canada Geol. Survey Mem. 153, 94 p., (no. 2121).

Williams, Neil, 1943, Development work spreads in black-oil horizons of Big Horn Basin, Wyo. : Oil and Gas Jour., v. 42, no. 29, p. 24-26.

* Winchester, D. E., 1919, Oil shales : Franklin Inst. Jour., v. 187, no. 6, p. 689-703.

*_ 1923, Oil shale of the Rocky Mountain region: U. S. Geol. Survey Bull. 729 , p. 20, 76-79, 82-87, 90-91, 127-129.

* Woodruff, E. G., 1909, Sulphur deposits near Thermopolis, Wyo.: U. S. Geol. Survey Bull. 380, p. 374.

Anonymous, 1942, Vanadium from phosphate rock : Eng. Min. Jour., v. 143, p. 61.

\section{OTHER MINERAL DEPOSITS AND FUELS IN THE WESTERN PHOSPHATE FIELD}

* Anderson, A. L., 1931, Geology and mineral resources of eastern Cassia County, Idaho: Idaho Bur. Mines and Geology Bull. 14, 169 p. Map, scale 1 in. to 2 mi. Averitt, Paul, and Berryhill, L. R., 1950, Coal resources of the United States: U. S. Geol. Survey Circ. 94, $33 \mathrm{p}$.

Ball, M. W., and Stebinger, Eugene, 1910, The eastern part of the Little SnakeRiver coal field, Wyoming: U. S. Geol. Survey Bull. 381., p. 186-213.

Beckwith, R. H., 1939, Asbestos and chromite deposits of Wyoming: Econ. Geology, v. 34, p. 812-843, 1939; Wyo. Geol. Survey Bull. 29.

Beeler, H. C., 1905, Geology and mineral resources of Wyoming: Am. Min. Cong., 7th, Proc., p. 113-118.

Bell, R. N., 1901, An outline of Idaho geology and of the principal ore deposits. of Lemhi and Custer Counties, Idaho: Internat. Min. Cong., 4th, Proc., p. 64-80.

1904, Geology of Park City (Utah) district: Lead and Zinc News, v. 8, p. 57,60 .

- 1904, Report of the mining districts of Idaho for the year 1903, 45 p., Boise.

- 1905, Report of the mining districts of Idaho for the year 1904, $139 \mathrm{p}$., Boise.

1905, The geology and mineral resources of Idaho: Am. Mining Cong.,. 7th, Proc., p. 200-226.

1918, Mineral resources of Idaho in Northwest Mines Handbook, v. 1, p. 27-30: Spokane, Sidney Norman.

- Bell, R. N., Moore, F. C., and Campbell, S., 1905-1921, Annual Reports of theMining Industry of Idaho.

Berrybill, H. L., Jr., Brown, D. M., and Brown, Andrew, 1950, Coal resources. of Wyoming: U. S. Geol. Survey Circ. 81, 78 p.

Blixt, J. E., 1932, The nonmetallic mineral resources of Montana: Pit and Quarry, v. 24, no. 7, p. 27-33.

Boutwell, J. M., 1905, Economic geology of the Bingham mining district, Utah, with a section on areal geology by Arthur Keith, and an introduction on general geology by S. F. Emmons: U. S. Geol. Survey Prof. Paper 38, 413 p.. 1905, Progress report on Park City mining district, Utah: U. S. Geol.. Survey Bull. 260, p. 150-153.

*__ 1912, Geology and ore deposits of the Park City district, Utah: U. S. Geol. Survey Prof, Paper 77, 231 p.; abs., Wash. Acad. Sci. Jour., v. 3, p. 445-447, [1913]. Map, scale 1:25,000.

Bowen, C. F., 1913, Lignite in the Goose Creek district, Cassia County, Idaho:: U. S. Geol. Survey Bull. 531, p. 252-262.

Breger, C. L., 1910, The salt resources of the Idaho-Wyoming border, with notes: on the geology: U. S. Geol. Survey Bull. 430, p. 555-569. 
Brown, P. L., 1950, Occurrence and genesis of trona in Sweetwater and Uinta Counties, Wyo.: Wyo. Geol. Soc. Guidebook 5, p. 136-137.

Burbank, W. S., and Lovering, T. S., 1933, Relation of stratigraphy, structure, and igneous activity to ore deposition of Colorado and southern Wyoming, in Ore Deposits of the Western States (Lindgren volume), p. 272-316: Am. Inst. Min. Metall. Eng.

Butler, B. S., 1919, Relation of ore deposits to thrust faults in the central Wasatch region, Utah: Econ. Geology, v. 14, p. 172-175.

- 1933, Summary, Pt. 1 of Ore deposits related to stratigraphic, structural, and igneous geology in the western United States, in Ore deposits of the Western States (Lindgren Volume), p. 198-240: An. Inst. Min. Metall. Eng.

* Butler, B. S., and others, 1920, The ore deposits of Utah: U. S. Geol. Survey Prof. Paper 111, 672 p. Maps, large and small scales.

* Calkins, F. C., and Butler, B. S., 1943, Geology and ore deposits of the Cottonwood-American Fork area, Utah, with sections on history and production by V. C. Heikes: U. S. Geol. Survey Prof. Paper 201, p. 22, 30-31, 89.

Chace, F. M., and others, 1947, Map showing metallic mineral deposits of Montana: U. S. Geol. Survey Missouri Basin Studies Map 16. Scale 1:1,000,000.

* Clabaugh, S. E., Larrabee, D. M., and Griffitts, W. R., 1946, Map showing construction materials and nonmetallic mineral resources of Wyoming: $\mathbf{U}$. S. Geol. Survey Missouri Basin Studies Map 9. Scale 1: 500,000.

Clark, F. R., 1918, Geology of the Lost Creek coal field, Morgan County, Utah : U. S. Geol. Survey Bull. 691, p. 311-322, 1918, abs., Wash. Acad. Sci. Jour., v. 9, p. 318-319, 1919.

—_ 1928, Economic geology of the Castlegate, Weilington, and Sunnyside quadrangles, Carbon County, Utah : U. S. Geol. Survey Bull. 793, 165 p.

Combo, J. X., Brown, D. M., and Pulver, H. F., 1949, Coal resources of Montana : U. S. Geol. Survey Circ. 53, 28 p.

Combo, J. X., Holmes, C. N., and Christner, H. R., 1950, Map showing coal resources of Montana: U. S. Geol. Survey Coal Inv. Map C 2 (2 sheets). Scale, 1 in. to about $8 \mathrm{mi}$.

Crawford, J. G., 1952, Natural gas as a source of elemental sulfur: Wyo. Geol. Assoc. Guidebook 7, p. 96-97.

Darton, N. H., 1906, Mineral resources of the Bighorn Mountain region: U. S. Geol. Survey Bull. 285, p. 309.

* Dobbin, C. E., Bowen, C. F., and Hoots, H. W., 1929, Geology of coal and oil resources of Hanna and Carbon Basins, Carbon County, Wyo.: U. S. Geol. Survey Bull. 804, 88 p.

Duncan, D. C., and Belser, Carl, 19ฮ0, Map showing geology and oil-shale resources of the eastern part of the Piceance Creek Basin, Rio Blanco and Garfield Counties, Colo.: U. S. Geol. Survey Oil and Gas Inv. Map OM 119. Scale, 1 in. to $8,000 \mathrm{ft}$.

Emmons, S. F., 1885, Geological sketch of the Rocky Mountain division: U. S. 10th Census, v. 13, p. 60-104.

- 1887, Notes on the geology of Butte, Mont. : Am. Inst. Min. Eng. Trans., v. 16, p. 49-62.

Emmons, S. F., and Tower, G. W., Jr., 1897, Economic geology of the Butte Special district: U. S. Geol. Survey Geol. Atlas, folio 38, p. 3-8. Map, scale $1: 15,000$.

Evans, G. W., 1924, Report on the Horseshoe Basin area of the Teton coal field in southeastern Idaho: Idaho Bur. Mines and Geol. Pamph. 10.

Fenneman, N. M., and Gale, H. S., 1906, The Yampa coal field, Routt County, Colo. : U. S. Geol. Survey Bull. 297, 81 p. 
Fischer, R. P., 1942, Vanadium deposits of Colorado and Utah, a preliminary report: U. S. Geol. Survey Bull. 936-P, p. 363-394. Maps, various scales.

Fischer, R. P., and others, 1946, Map showing metallic mineral deposits of Colorado: U. S. Geol. Survey Missouri Basin Studies Map 8. Scale 1: 1,000,000.

- 1947, Map showing metallic mineral deposits of Wyoming: U. S. Geol. Survey Missouri Basin Studies Map 17. Scale, 1: 1,000,000.

Fisher, C. A., 1904, Coal of the Bighorn Basin, in northwest Wyoming: U. S. Geol. Survey Bull. 225, p. 345-362.

1906, Mineral resources of the Bighorn Basin, Wyo.: U. S. Geol. Survey Bull. 285, p. 311-315.

Gabriel, Clarence, 1940, Non-metallics in Utah : Compass, v. 20, p. 82-84.

Gale, H. S., 1909, Coal fields of northwestern Colorado and northeastern Utah: U. S. Geol. Survey Bull. 341, p. 283-315. Maps, scale 1 in. to $4 \mathrm{mi}$.

1910, Coal fields of northwestern Colorado and northeastern Utah: U. S. Geol. Survey Bull. 415, 265 p.

-1910, Geology of the copper deposits near Montpelier, Bear Lake County, Idaho: U. S. Geol. Survey Bull. 430, p. 112-121.

Gooldy, P. L., 1947, Embar and Tensleep crude oil gravities: Wyo. Geol. Assoc. Guidebook 2.

Green, Jack, and Young, W. A., Jr., 1937, The Park City mining district (Utah) : Compass, v. 17, p. 159-162.

Hart, R. A., 1932, The nonmetallic mineral resources of Utah: Pit and Quarry, v. 24, no. 13, p. 29-34, 1932 ; Utah Eng., v. 7, p. 1-3.

Hauptman, C. A., 1950, The Spring Valley, Aspen and Sulphur Creek fields: Wyo. Geol. Assoc. Guidebook 5, p. 117-118.

Heinrich, E. W., 1949, Pegmatite mineral deposits in Montana : Mont. Bur. Mines and Geology Mem. 28, $56 \mathrm{p}$.

Hewett, D. F., 1913, Sulphur deposits of Sunlight Basin, Wyo.: U. S. Geol. Survey Bull. 530, p. 350-362.

_ 1914, Sulphur deposits in Park County, Wyo.: U. S. Geol. Survey Bull. 540, p. $477-480$.

- 1928, A manganese deposit of Pleistocene age in Bannock County, Idaho: U. S. Geol. Survey Bull. 795, p. 211-218.

*Hewitt, E. A., 1928, Exploration methods in the Park City, Utah, district: Min. Cong. Jour., v. 12, p. 54-55.

Hintze, F. F., Jr., 1915, The Basin and Greybull oil and gas fields, Big Horn County, Wyo.: Wyo. State Geologists Off. Bull. 10, 62 p.

Holser, W. T., 1950, Metamorphism and associated mineralization in the Philipsburg region, Montana: Geol. Soc. America Bull., v. 61, no. 10, p. 1053-1090. Maps, various scales.

Hubley, M. D., 1948, The Beaver Creek field, Fremont County, Wyo.: Wyo. Geol. Assoc. Guidebook 3, p. 160-165.

Hunt, R. N., 1924, The ores in limestone at Bingham, Utah : Am. Inst. Min. Metall. Eng. Trans., v. 70, p. 856-883.

Hunter, W. S., Jr., 1950, The Kemmerer coal field : Wyo. Geol. Assoc. Guidebook 5, p. 123-132.

Huttl, J. B., 1951, The Greater Butte project: Eng. Min. Jour., v. 152, no. 10, p. $72-81$.

Jones, R. L., and Wilson, S. R., 1949, Diamond drilling at the Boston Consolidated Copper Mine, Salt Lake County, Utah: U. S. Bur. Mines Rept. Inv. 4579, $21 \mathrm{p}$.

*Karlstrom, T. N. V., 1948, Geology and ore deposits of the Hecla mining district, Beaverhead County, Mont. : Mont. Bur. Mines and Geology Mem. 25, $87 \mathrm{p}$. Maps, scales 1 in. to $1000 \mathrm{ft}$., 1 in. to $1 / 2 \mathrm{mi}$. 
${ }^{*}$ Knechtel, M. M., Larrabee, D. M., and Fischer, F. C., 1948, Map showing construction materials and nonmetallic mineral resources of Montana: U. S. Geol. Survey Missouri Basin Studies Map 11 (west half). Scale, 1: 750,000.

Knight, W. C., 1903, Coal fields of southern Uinta County, Wyo. [abs.] : Geol. Soc. America Bull., v. 13, p. 542-544.

Knopf, Adolph, 1913, Ore deposits of the Helena mining region, Montana : U. S. Geol. Survey Bull. 527, p. 22. Map, scale 1:250,000.

Koeberlin, F. R., 1938, Sedimentary copper, vanadium-uranium, and silver in southwestern United States: Econ. Geology, v. 33, p. 458-461.

Lakes, Arthur, 1898, Mount Caribou gold deposits [abs.] : Mines and Minerals, v. 19, p. 55-56.

Larrabee, D. M., Clabaugh, S. E., and Dow, D. H., 1945, Mineral resources of the Missouri Valley region-part 2, Nonmetallic mineral resources: U. S. Geol. Survey Missouri Basin Studies Map 1. Map, scale 1: 2,500,000.

Larrabee, D. M., and others, 1947, Preliminary map showing construction materials and nonmetallic mineral resources of Colorado: U. S. Geol. Survey Missouri Basin Studies Map 10. Scale 1: 500,000.

Larrabee, D. M., and Shride, A. F., 1946, Preliminary map showing sand and gravel deposits of Wyoming: U. S. Geol. Survey Missouri Basin Studies Map 5. Scale 1: 500,000.

- 1946, Preliminary map showing sand and gravel deposits of Montana : U. S. Geol. Survey Missouri Basin Studies Map 6 (west half). Scale $1: 500,000$.

Larsen, R. M., 1950, Oil and gas developments in the Rocky Mountain region during 1949 : Jour. Petroleum Technology, v. 2, p. 343-367.

* Lovering, T. S.; 1939, The New World or Cook City mining district, Park County, Mont.: U. S. Geol. Survey Bull. 811, p. 1-87. Map, scale 1: 31,680.

Lupton, C. T., 1912, The Deep Creek district of the Vernal Coal field, Uinta County, Utah : U. S. Geol. Survey Bull. 471, p. 579-594.

1912, The Blacktail (Tabby) Mountain coal field, Wasatch County, Utah : U. S. Geol. Survey Bull. 471, p. 595-628.

1916, Oil and gas near Basin, Big Horn County, Wyo.: U. S. Geol. Survey Bull. 621, p. 157-190.

Lyden, C. J., 1948, The gold placers of Montana : Mont. Bur. Mines and Geology Mem. 26, $152 \mathrm{p}$.

McGlashan, Donald W. and Roys, Perry F., 1951, The tungsten situation in Montana as a factor in national defense: Mont. Bur. Mines and Geology Memo., Misc. Contr., 12, [1952].

McKay, G. R., 1028, Paxls City, a lend-silver district in Utah : Eng. Min. Jour.Press, v. 116, p. 7-14.

Majors, F. H., 1946, Exploration of the Brutch sulfur deposits, Hot Springs County, Wyo.: U. S. Bur. Mines Rept. Inv. 3964, 18 p.

Mansfleld, G. R., 1921, Coal in eastern Idaho: U. S. Geol. Survey, Bull. 716, p. $123-153$.

* 1927, Geography, geology, and mineral resources of part of southeastern Idaho: U. S. Geol. Survey Prof. Paper 152, 409 p. Maps, various scales.

Marzell, J. G., 1929, Developed and undereloped mineral resources of Wyoming: Wyo. Geol. Survey Bull. 21, p. 85-90.

Moody, C. L., and Taliaferro, N. L., 1918, Anticlines near Sunshine, Park County, wyo.: Calif. Univ. Dept. Geol. Bull. 10, p. 445-459. Map, scale 1 in. to about $11 / 3 \mathrm{mi}$.

* Newton, Joseph, and Finklenburg, O. C., 1947, Beneficiation of Idaho phosphate rock: Bur. Mines and Geology, Idaho Min. Res. Rept. 3, 22 p. 
Nightingale, W. T., 1930, Geology of Vermillion Creek gas area in southwest Wyoming and northwest Colorado: Am. Assoc. Petroleum Geologists Bull., v. 14, no. 8, p. 1013-1040; abs., Pan-Am. Geologist, v. 53, no. 3, p. 227-228.

* Nolan, T. B., 1935, The Gold Hill mining district, Utah: U. S. Geol. Survey Prof. Paper 177, p. 39-42. Maps, scale $1: 24,000,1: 62,500$.

Pardee, J. T., 1913, Coal in the Tertiary lake beds of southwestern Montana: U. S. Geol. Survey Bull. 531, p. 229-244. Map, scale 1 : 750,000.

- Pardee, J. T., and Schrader, F. C., 1933, Metalliferous deposits of the Greater Helena mining region, Montana : U. S. Geol. Survey Bull. 842, 318 p. Map, scale $1: 250,000$.

Parsons, W. H., 1937, The ore deposits of the Sunlight mining region, Park County, Wyo.; Econ. Geology, v. 32, p. 832-854; abs., v. 2, p. 199.

Perry, E. S., 1932, The Butte mining district, Montana: Internat. Geol. Cong., 16th sess., United States, 1933, Guidebook 23, Excursion C-2, 25 p. Maps, various scales.

- 1948, Talc, graphite, vermiculite, and asbestos deposits in Montana: Mont. Bur. Mines and Geology Mem. 27, $44 \mathrm{p}$.

* Pierce, W. G., and Andrews, D. A., 1941, Geology and oil and coal resources of the region south of Cody, Park County, Wyo.: U. S. Geol. Survey Bull. 921-B, p. 99-180. Map, scale $1: 63,360$.

- Richards, R. W., 1910, Notes on the lead and copper deposits in the Bear River Range, Idaho and Utah: U. S. Geol. Survey Bull. 470, p. 177-204.

Richards, R. W., and Bridges, J. H., 1911, Sulfur deposits near Soda.Springs, Idaho: U. S. Geol. Survey Bull. 470, p. 499-503.

Ross, C. P.; 1950, Fluorspar prospects of Montana: U. S. Geol. Survey Bull. 955-E, p. 173-224.

Ross, C. P., and Carr, M. S., 1941, The metal and coal mining districts of Idaho, with notes on the non-metallic mineral resources of the State: Idaho Bur. Mines and Geology Pamph. 57, pt. 1, p. 108-109.

Rowe, J. P., 1928, Minor minerals and non-metallic minerals of Montana : Eng. Min. Jour., v. 125, p. 816-818.

* Sahinen, U. M., 1950, Geology and ore deposits of the Highlands Mountains, southwestern Montana: Mont. Bur. Mines and Geology Mem. 32, 63 p. Map, scale 1 in. to $1 \mathrm{mi}$.

'Sales, R. H., 1914, Ore deposits at Butte, Mont.: Am. Inst. Min. Metall. Eng. Trans., v. 46, p. 3-106.

:Sales, R. H., and Meyer, Charles, 1948, Wall rock alteration at Butte, Mont.: Am. Inst. Min. Metall. Eng. Tech. Pub. 2400, 25 p.

1949, Results from preliminary studies of vein formations at Butte, Mont. : Econ. Geology, v. 44, p. 465-484.

Sanford, Samuel, and Stone, R. W., 1914, Useful minerals of the United States: U. S. Geol. Survey Bull. 585, p. 67, 112, 187, 217.

'Schrader, F. C., Stone, R. W., and Sanford, Samuel, 1917, Useful minerals of the United States: U. S. Geol. Survey Bull. 624, p. 119, 184, 305-306, 347.

Schultz, A. R., 1910, The southern part of the Rock Springs coal field, Sweetwater County, Wyo. : U. S. Geol. Survey Bull. 381, p. 214-281.

1909, The northern part of the Rock Springs coal field, Sweetwater County, Wyo. : U. S. Geol. Survey Bull. 341, p. 256-282.

1910, Deposits of sodium salts in Wyoming: U. S. Geol. Survey Bull. 430, p. 570-589.

Sears, J. D., 1924, Geology and oil and gas prospects of part of Moffat County, Colo., and southern Sweetwater County, Wyo.: U. S. Geol. Survey Bull. 751, p. 269-319. 
Sears, J. D., and Bradley, W. H., 1925, Relations of the Wasatch and Green River formations in northwestern Colorado and southern Wyoming, with notes on oil shale in the Green River formation: U. S. Geol. Survey Prof. Paper 132, p. 93-107.

Shannen, E. V., 1926, The minerals of Idaho: U. S. Natl. Mus. Bull. 131, 483 p.

Sharkey, H. H. R., Love, J. D., and Kirby, Jewell, 1945, Map of Wyoming showing test wells for oil and gas, anticlinal axes, and oil and gas fields: U. S. Geol. Survey Oil and Gas Inv. Prelim. Map 19. Scale 1: 500,000.

Sinkler, Helen, 1942, Geology and ore deposits of the Dillon nickel prospect, southwestern Montana: Econ. Geology, v. 37, p. 136-152. Map, scale 1 in. to about $2400 \mathrm{ft}$.

Spencer, A. C., 1916, The Atlantic gold district, Fremont County, Wyo.: U. S. Geol. Survey Bull. 626, 85 p.

Spieker, E. M., 1925, Geology of the coal fields [of Utah] : U. S. Bur. Mines Tech. Paper 345, p. 13-22.

— 1931, The Wasatch Plateau coal field, Utah : U. S. Geol. Survey Bull. 819, $210 \mathrm{p}$.

Staley, W. W., and Prater, L. S., 1945, Sulfur in Idaho: Idaho Bur. Mines and Geology Min. Res. Rept. 2, 7 p.

Stone, R. W., and Lupton, C. T., 1910, The Powder River coal field, Wyo., adjacent to the Burlington Railroad: U. S. Geol. Survey Bull. 381, p. 115-136.

Thompson, R. B., 1937, Utah sulphur industries : Compass, v. 17, p. 166-169.

Umpleby, J. B., 1917, Geology and ore deposits of the Mackay region, Idaho: U. S. Geol. Survey Prof. Paper 97, 129 p.

1917, The manganese deposits of Philipsburg, Mont.: Min. Sci. Press, v. 115 , p. 725 .

United States Geological Survey, 1942, Coal fields of the United States. Map, scale $1: 2,500,000$.

- 1946, Oil and gas fields of the United States. Map, scale $1: 2,500,000$.

Varnes, Helen, and Larrabee, D. M., 1946, Preliminary map showing sand and: gravel deposits of Colorado: U. S. Geol. Survey Missouri Basin Studies Map. 2. Scale, $1: 500,000$.

Veatch, A. C., 1906, Coal and oil in southern Uinta County, Wyo.: U. S. Geol. Survey Bull. 285, p. 331-353. Map, scale 1 in. to $5 \mathrm{mi}$.

* - 1907, Geography and geology of a portion of southwestern Wyoming, with special reference to coal and oil: U. S. Geol. Survey Prof. Paper 56, $178 \mathrm{p}$.

Washburne, C. W., 1909, Coal fields of the northeast side of the Bighorn Basin, Wyo., and of Bridger, Mont.: U. S. Geol. Survey Bull. 341, p. 165-199.

Weed, W. H., 1912, Geology and ore deposits of the Butte district, Mont.: U. S. Geol. Survey Prof. Paper 74, 262, p. abs., Wash. Acad. Sci. Jour., v. 3, p. 363-364, 1913.

Weeks, F. B., and Heikes, V. C., 1908, Notes on the Fort Hall mining district, Idaho: U. S. Geol. Survey Bull. 340, p. 37-87.

* Winchell, A. N., 1914, Mining districts of the Dillon quadrangle, Mont., and adjacent areas: U. S. Geol. Survey Bull. 574, p. 26. Maps, various scales. Abs., Wash. Acad. Sci. Jour., v. 5, p. 23, 1915.

woodruff, E. G., 1908, Sulfur deposits at Cody, Wyo.: U. S. Geol. Survey Bull. 340, p. 451-456.

1909, Sulfur deposits near Thermopolis, Wyo.: U. S. Geol. Survey Bull. 380 , p. $373-380$.

1909, Coal fields of the southwest side of the Big Horn Basin, Wy0.: U. S. Geol. Survey Bull. 341, p. 200-219. 
Woodruff, E. G., 1910, The coal field in the southeastern part of the Bighorn Basin, Wyo.: U. S. Geol. Survey Bull. 381, p. 170-185.

- 1914, The Horseshoe Creek district of the Teton Basin coal field, Fremont County, Idaho: U. S. Geol. Survey Bull. 541, p. 379-388.

Woodruft', E. G., and Winchester, D. E., 1912, Coal fields of the Wind River region, Fremont and Natrona Counties, Wyo.: U. S. Geol. Survey Bull. 471, p. 516-564.

Young, W. A., 1950, Investigation of Eagle Silver lead-zinc mine, Tooele County, Utah: U. S. Bur. Mines Rept. Inv. 4680, 11 p.

Zalinski, E. R., 1911, Ore occurrence at Little Bell mine (Park City, Utah) : Eng. and Min. Jour., v. 91, p. 1101-1103.

Ziegler, Victor, 1917, The Oregon Basin gas and oil field, Park County, [Wyo.]: Wyo. Geologist's Office Bull. 15, p. 211-242.

1917, The Byron oil and gas field, Big Horn County, [Wyo.]: Wyo. Geologist's Office Bull. 14, p. 181-207. 